\title{
Trends in Time Allocation: A Cross-Country Analysis
}

\author{
J. Ignacio Gimenez-Nadal \\ University of Zaragoza \\ Almudena Sevilla \\ Queen Mary University of London \\ and IZA
}

Discussion Paper No. 6709
July 2012

IZA
P.O. Box 7240
53072 Bonn
Germany

Phone: +49-228-3894-0

Fax: +49-228-3894-180

E-mail: iza@iza.org

\begin{abstract}
Any opinions expressed here are those of the author(s) and not those of IZA. Research published in this series may include views on policy, but the institute itself takes no institutional policy positions.

The Institute for the Study of Labor (IZA) in Bonn is a local and virtual international research center and a place of communication between science, politics and business. IZA is an independent nonprofit organization supported by Deutsche Post Foundation. The center is associated with the University of Bonn and offers a stimulating research environment through its international network, workshops and conferences, data service, project support, research visits and doctoral program. IZA engages in (i) original and internationally competitive research in all fields of labor economics, (ii) development of policy concepts, and (iii) dissemination of research results and concepts to the interested public.
\end{abstract}

IZA Discussion Papers often represent preliminary work and are circulated to encourage discussion. Citation of such a paper should account for its provisional character. A revised version may be available directly from the author. 


\section{ABSTRACT}

\section{Trends in Time Allocation: A Cross-Country Analysis*}

Using detailed time-use data for seven industrialized countries from the 1970s until today we document general decreases in men's market work coupled with increases in men's unpaid work and child care, and increases in women's paid work and child care coupled with decreases in unpaid work. We also find almost universal increases in the time devoted to watching television over this period, and uncover a widespread increase in leisure inequality in favor of lower educated adults. Trends in leisure inequality mirror the general increase in income and earnings inequality experienced in most countries over this period, especially after the mid-1980s. All these findings are consistent with previous results for the US. However, in contrast to the increases in leisure found for the US, we fail to find common trends in leisure time across countries over the period analyzed.

JEL Classification: D12, D13, J2

Keywords: time use survey, leisure inequality

Corresponding author:

Almudena Sevilla

Queen Mary University of London

Department of Business and Management

Francis Bancroft Building

Mile End Road

London E1 4NS

United Kingdom

E-mail: a.sevilla@qmul.ac.uk

\footnotetext{
* We would like to thank Dan Hamermesh, Tony Atkinson and seminar participants at the Discussion Meeting at the The Institute for New Economic Thinking at the Oxford Martin School (2011), the conference of the European Society for Population Economics (2010), and the conference of the European Economic Association (2011). We thank Lonnie Golden (Penn State University) and Jon Messenger (International Labour Organization) for kindly providing data on statuary paid leave for different countries. The views expressed in this paper are solely those of the authors and may not reflect the views of the creators or funders of MTUS or the collectors of the original surveys harmonized in this data set. This paper has benefited from the funding from the Economic and Social Research Council (Grant Number RES-060-25-0037) and the Spanish Ministry of Education and Science (Project ECO2008-01297).
} 


\section{INTRODUCTION}

It can be argued that the fundamental scarce resource in the economy is time. More importantly, unlike the scarcity of goods, the 24 hours per day time constraint does not relax in a growing economy (Hamermesh and Lee, 2007). Uncovering how individuals allocate their time outside of the market is thus crucial for increasing our understanding of the dynamics of economic change and welfare. Except for some pioneer exceptions (Juster and Stafford, 1985; Kooreman and Kapteyn, 1987; Biddle and Hamermesh, 1990), economists have -perhaps surprisingly- yet to pay serious attention to the use of time other than in the context of labor supply (see Hamermesh and Pfann (2005) for a recent review of the state of the art). The aim of this paper is to address this major omission. We use detailed time-use data for seven developed countries to examine the trends in the allocation of time from the mid-1970s until today, and document how the time devoted to leisure, work, and parental child care has evolved for men and women of different educational attainment.

We find no clear trends in leisure time across countries over the relevant period. We document that leisure increased for men in Australia, Finland and the United Kingdom an average of about 4 hours per week. In France, the Netherlands and Norway men experienced a smooth decline in leisure by an average of almost 5 hours per week. Leisure time remained relatively constant for men in Canada over the relevant period. Changes in leisure were less pronounced for women. Leisure time decreased for women in Canada, the Netherlands, Norway and the UK by 2 hours and 50 minutes per week over the relevant period, and remained constant for Australian and French women. Finland is the only country where women experienced an increase in leisure, by about 6 hours per week, especially during the 1990s.

Whereas increases in unpaid work and child care were mostly financed by declines in paid work for men (with the exception of France and the Netherlands), decreases in unpaid work (and to a lesser extent leisure) financed the increases in the time devoted to paid work and child care for women in all countries (except for Finland). We document almost universal decreases in men's market work (an average of 4 hours and 45 minutes per week), with the exception of France and the Netherlands. Men increased the time devoted to unpaid work and child care activities in all countries by an average of 3 hours and 35 minutes, and 1 hour per week (even in countries where leisure also increased). Women increased the time devoted to paid work in almost all countries, by an average of 6 hours and 35 minutes, and decreased the time devoted to unpaid work (by 5 hours and 45 minutes per week on average). Child care increased in most countries for women (by an average of 1 hour and 20 minutes per week), with the exception of Canada and the Netherlands where child care time remained constant over the analyzed period. 
There are substantial increases in the time spent watching television in most countries, with an overall increase of over 2 hours per week for men and women. The only exceptions to this increasing trend are men in the Netherlands, and women in Australia, the Netherlands and the UK. Men and women also increased the time devoted to sports by about 1 hour and 20 minutes per week in all countries. With few exceptions, the time spent sleeping also increased, by 1 hour and 45 minutes per week for men, and 2 hours and 5 minutes per week for women. In most countries, men decreased the time spent reading (by 1 hour and 25 minutes per week), eating (by 2 hours per week), and the time devoted to personal care activities (by an average of 1 hour and 55 minutes per week). Women also spent 2 hours per week less eating by the end of the period in most countries, with the exception of France where time devoted to eating increased by 1 hour, and less time reading ( 1 hour and 5 minutes per week).

We also show a growing inequality in leisure in favor of less educated adults in all countries. We look at two different moments of the leisure distribution, the Gini Index for leisure and the ratio of the $90^{\text {th }}$ percentile and the $10^{\text {th }}$ percentile of leisure. Both measures seem to suggest that inequality steadily increased in most countries over the relevant period. We also explore trends in leisure inequality by educational status, with low educated adults having increased (decreased) their leisure to a greater (lesser) extent than highly educated adults. In turn, the spread in the leisure distribution resulted in less educated men and women experiencing a relative gain in leisure with respect to highly educated adults in most countries.

Most of the divergence in leisure time for both men and women across educational groups is concentrated in the middle of the period, particularly in the 1980s and 1990s, which coincides with the well-documented change in wages and consumption between education groups during recent decades in these countries. Differences in leisure across the education distribution are due primarily to differences in paid work, which increased (decreased) more (less) for highly educated adults. Among leisure activities, socializing stands out as the factor explaining the divergence in leisure between educational groups. Although the time spent socializing decreased in some countries and increased in others, it seems that in those countries where the time spent in socializing activities increased, it increased more for high-school drop outs, and in those countries where the time spent socializing decreased, it decreased more for individuals with at least some college.

By studying several countries over a long period of time our work crucially adds to the study of trends in the allocation of time in the US, including the most recent work by Aguiar and Hurst's (Aguiar and Hurst 2007, 2009), and previous notable research such as Ghez and Becker (1975), Juster and Stafford (1985), and Robinson and Godbey (1999). Specifically, we are able to improve our understanding of how changes in the allocation of time experienced in the 
United States compares to changes in a broad group of other industrialized economies. In contrast to the previously reported increases in leisure for the US, we fail to find any uniform trend in leisure time for men and women across the countries in our sample. As in the US however, we document decreases in men's market work coupled with increases in men's unpaid work and child care, and increases in women's paid work and child care coupled with decreases in unpaid work for most countries. We also find almost universal increases in the time devoted to watching television over this period, and uncover a widespread increase in leisure inequality over the period that closely resembles the evidence reported by Aguiar and Hurst (2007) for the US. Our paper also expands recent cross-country studies such as Burda, Hammermesh and Weil (2008), Gershuny (2009a), Hook (2006), and Gauthier, Smeeding, and Furstenberg (2004) among others. These studies generally use earlier data to document changes in the use of time for a variety of developed economies from the early and mid-1970s until the mid-1990s. Our paper analyses a greater number of countries over a longer time period, and extends these crosscountry comparisons by additionally documenting for the first time a generalized growing dispersion in leisure.

The remainder of the paper is organized as follows. Section 2 describes the data and the variables used in the analysis. Section 3 shows trends in time allocation decisions of individuals from the selected countries. Section 4 shows how leisure inequality has evolved over the period. Section 5 sets out the main conclusions.

\section{DATA AND VARIABLES}

We examine diary data since the 1970s for the following industrialized countries (corresponding sample years in parentheses): Australia (1974-1982-1992-1997), Canada (19711981-1986-1992-1998), Finland (1979-1987-1999), France (1974-1998), the Netherlands (1975-1980-1985-1990-1995-2000-2005), Norway (1971-1981-1990-2000), and the UK (19751983-1987-1995-2000). Our choice of countries and time periods is based on the availability of data based on 24-hour time diaries, which minimizes comparability issues across surveys in time use categories (see also Guryan, Hurst and Kearney (2008) for a discussion about the conceptualization and comparability of child care time using these surveys). A diary is completed by respondents on selected days, and is divided into intervals where the respondent records a main activity (and other features depending on the survey such as the secondary activity carried out simultaneously with the primary activity, whether the activity was performed in the company of a child, another member of the household, or another adult, and where the activity took place). An extensive literature confirms the reliability and validity of 
diary data and their superiority over other time-use surveys based on stylized questions, asking respondents to estimate time in activities on a 'typical day' (e.g., Robinson and Godbey 1985; Juster and Stafford 1985). In the labor supply literature for example, Klevmarken (2005) argues that information on actual hours of work from time-use surveys are more relevant than normal hours or contracted hours generally reported in stylized questions. He shows that time-use data yields much smaller estimates of wage rate effects compared to measures of normal hours of work, which may have important implications for tax policy design among others. Thus, the same way money expenditure diaries have become the gold standard in the consumption literature, so have time-use diaries become the preferred method to gather information on time spent on market work, non-market work and leisure. Most studies documenting long term trends in how individuals use their time are now based on these data sets, including recent studies for the analysis of trends in time use (e.g. Guryan et al. 2008, Aguiar and Hurst 2007, Krueger 2007).

Our data come from the Multinational Time Use Study (MTUS), an ex-post harmonized cross-time, cross-national comparative time-use database, constructed from national randomsampled time-diary studies with detailed measures of time use. The MTUS aggregates daily 'primary activity' in 40 time use categories (and an additional category for missing time), with approximately 30 standardized demographic variables. The fact that most of our analysis is based on the comparison of broad classification of activities (i.e., leisure, paid work, unpaid work and child care) provides a good basis to run meaningful comparisons over time and across countries. A word of caution is needed when comparing the exact amount of time spent in finer leisure activities across countries in Section 3 (such as the time spent watching television, or reading), given that time use activities may have been coded differently across surveys. As Aguiar and Hurst (2007) point out however, to the extent that low and highly educated individuals are affected by data collection methods in the same way, the comparison of time use trends between educational groups should remain unaffected by survey methodology and so comparisons of finer leisure activities between education groups should still be valid. Furthermore, the harmonization exercise also addressed differences in survey methodologies such as different response rates (especially the lower response rate of some of the surveys), whether they covered or not the twelve months of the year, and the sampling frame. All the surveys provide weights designed to ensure that the surveys are nationally representative. Table A1 in Appendix A shows the countries and surveys we use in our analysis, and gives the total (unweighted) numbers of diary evidence available in for each country and survey.

For the sake of comparison with previous studies (e.g., Aguiar and Hurst 2007), and to minimize the role of time allocation decisions that have a strong inter-temporal component over 
the life cycle, such as education and retirement, we restrict the sample used throughout the analysis to non-retired/non-student individuals between the ages of 21 and 65 (inclusive), so results should be interpreted as being 'per working-age adult'. We also use the demographic weighting as proposed by Katz and Murphy (1992) to ensure a constant representation of types of individuals and days of the week. ${ }^{1}$ Appendix B gives a detailed description of how demographic weights are computed for each country based on the demographic characteristics in Table 1. The demographic composition is different across countries and over time, which may explain differences in time use patterns. For example, a younger or more educated population may be associated with less leisure time and more time devoted to paid work. Similarly, different fertility rates may imply different child care times. It is thus important to keep constant the demographic composition of the population to run meaningful comparisons over time and across countries.

The conceptualization of time use categories is usually driven by a systematic, principledriven approach of distinguishing means vs. ends. The so-called third person criterion for example, excludes from the definition of leisure any activity that might be carried out by some third party without losing the intended utility for the final consumer. Unfortunately, the third person criterion involves questionable assumptions such that the enjoyment derived from work can legitimately be ignored, and that all leisure is enjoyable. However, one quarter of time that would be considered leisure according to the conventional implementation of the third person criterion, and one third of what would conventionally be considered work, is unexpectedly placed by the diarists (Gershuny 2009b). Certain activities, such as sleeping, eating, personal and medical care, or resting, do not fall comfortably into the means vs. ends classification. These activities cannot be purchased in the market, but they may not be considered leisure in the sense that they are necessary for life. Nonetheless, some variation in the time spent in these activities may result from conscious choice. Biddle and Hamermesh (1990) show that sleep time responds to economic incentives such as the wage. Decreasing marginal utility of sleep (and of other consumption activities) is indeed shown by Gershuny (2009b) using (subsequent) diary reports of enjoyment. Similarly, many of the tasks constituting child care can be purchased in the market, so it could be conceptualized as a part of unpaid production (e.g., Guryan, Hurst and Kearney 2008; Aguiar and Hurst 2007; Fisher et al. 2007). However, parents report that the time with their children is among their more enjoyable activities, especially when compared with

\footnotetext{
${ }^{1}$ Similar analyses without population-constant weights do not qualitatively change our results (available upon request). We have also conditioned the change in time spent in various activities on demographics by running regressions controlling for age, education, presence of children under 18 in the household, and the day of the week. Results are qualitatively very similar for most countries and time use categories, so we assume a constant demographic composition over the reference period for the rest of the analysis.
} 
other standard home production activities (e.g., Guryan, Hurst and Kearney 2008, Krueger 2007; Kahneman and Krueger 2006; Kahneman et al. 2004; Robinson and Godbey 1985; Juster and Stafford 1985).

Rather than trying to resolve this debate on theoretical grounds, we adopt an empirical approach, and follow Aguiar and Hurst (2007) in the definition of time use categories. According to these authors, we consider the following categories (see Appendix A Table A2 for an overview of the activities included in our definition of activities):

Paid work includes all time spent working in the paid sector on main jobs, second jobs, and overtime, including any time spent working at home, plus time spent commuting to/from work.

Unpaid work includes any time spent on meal preparation and cleanup, doing laundry, ironing, dusting, vacuuming, indoor household cleaning, indoor design and maintenance (including painting and decorating), time spent obtaining goods and services (i.e., grocery shopping, shopping for other household items, comparison shopping), and time spent on other home production such as home maintenance, outdoor cleaning, and vehicle repair. ${ }^{2}$

Child care includes all the time devoted to child care as primary activity (e.g., feeding and food preparation for babies and children; washing, changing babies and children; putting children and babies to bed or getting them up; babysitting; medical care of babies and children; reading to, or playing with babies and children; helping children with homework; supervising children). ${ }^{3}$

Leisure includes activities such as watching television, sports, general out-of-home leisure, gardening and pet care, and socializing, and coincides with the definition of Leisure Measure 2 in Aguiar and Hurst (2007). ${ }^{4}$ Results are consistent to the use of other alternative measures of leisure (see Tables C3, C4 and C5 in Appendix C for a description of these results).

\footnotetext{
${ }^{2}$ We have also analyzed trends for different definitions of unpaid work as in Aguiar and Hurst (2007). In particular, the following non-market work activities were considered: "Housework 1" is defined as the time spent in "Cook/wash up" and "Housework". "Housework 2" is defined as the time spent in "Cook/wash up", "Housework" and "Shopping". "Housework 3" is defined as the time spent in "Cook/wash up", "Housework", "Shopping" and "Other domestic work". Tables C1 and C2 in Appendix $\mathrm{C}$ show that trends in the time devoted to each of these non-market work activities are similar to the trends for our definition of unpaid work (which is "Housework 3" plus "Domestic Travel").

${ }^{3}$ There is a concern however that child care reported as primary activity significantly underestimates total child care time (e.g., Budig and Folbre 2004; Folbre and Bittman 2004; Bianchi 2000), as it does not take into account other time that parents spend supervising children. We acknowledge that our results rely on this simpler definition of child care.

${ }^{4}$ Fahr (2005) includes reading journals and newspapers as "informal education", although describes such activities as "part of daily leisure time" as we do. Eating, sleeping, and personal care is sometimes considered a category of interest of its own - along with paid work, unpaid work, and leisure-, as in Gauthier, Smeeding and Furnstenberg (2004) and Burda, Hamermesh and Weil (2008). Table C6 in
} 


\section{TRENDS IN TIME USE}

\subsection{General Changes in Time Allocation}

Tables 2 and 3 show the trends in the time devoted to leisure (Panel A), paid work (Panel B), unpaid work (Panel C), and child care (Panel 4) for both men and women, respectively.

Leisure evolved differently for men in different countries. Leisure increased for men in Australia, Finland, and the United Kingdom, while in France, the Netherlands and Norway men experienced a decline in leisure. Leisure ranged between 103 and 114 hours per week in the 1970s, and between 105 and 118 hours per week by the end of the period. In Australia, Finland and the United Kingdom, leisure increased an average of about 4 hours per week over the relevant period, especially in the 1990s. In France, the Netherlands, and Norway men experienced a relatively smooth decline in leisure by an average of almost 5 hours per week over the relevant period. In Canada, leisure remained relatively constant. Changes in leisure have been mostly concentrated on the 1990s and 2000s, while the 1970s and 1980s were periods of relative stability.

Decreases in paid work and to a lesser extent in leisure time financed the increases in unpaid work and child care for men in most countries. Men increased the time devoted to unpaid work and child care activities in all countries, even in countries where leisure also increased. The time devoted to unpaid work was between 8 and 15 hours per week in the 1970s, and between 11 and 17 hours per week by the end of the period..$^{5}$ The time spent on child care activities also increased over the relevant period in all countries, although to a lesser extent than unpaid work, ranging between 0.5 and 2 hours per week at the beginning of the period, and between 2 and 3 and a half hour by the end of the period. Increases in unpaid work and child care were mostly financed by declines in paid work. Paid work declined for men an average of 7 hours and 30 minutes per week (with the exceptions of France and the Netherlands where men experienced an increase of 1 hour and 30 minutes, and 4 hours per week, respectively). Greater decreases in leisure made it still possible for men to devote more time to unpaid work and child care in these countries. Paid work ranged between 39 and 53 hours per week at the beginning of the period,

Appendix $\mathrm{C}$ shows how the time devoted to eating, sleeping and personal care has changed over this period. Although trends in the aggregate time devoted to these activities do not necessarily resemble leisure trends in all countries, leisure trends are robust to the exclusion of these categories (Table C3 in Appendix C), so we restrict the main analysis to only four time use categories (paid work, unpaid work, child care than leisure) and include these activities in the definition of leisure for the sake of simplicity.

${ }^{5}$ It is beyond the aim of this paper to assess the channels behind the patterns of time use documented here. See Jacobsen and Kapteyn (2005) for an interesting exercise using Dutch data between 1995 and 2005. They show that a change in shopping hours regulations not only had a positive effect on the total time devoted to shopping, but also on the time devoted to paid work. 
to a range of between 31 and 44 hours per week by the end of the period. There seems to be some convergence in the case of paid work, whereby countries where men had a relatively high number of paid work hours (such as Australia and the UK) experienced the greater declines in paid work hours, whereas in countries with lower levels of paid work at the beginning of the period experienced a lower decline.

Leisure decreased for women in Canada from the mid 1970s to the 1990s by 2 hours per week, and in the Netherlands, Norway and the UK to the mid 2000s on average by 3 hours per week. The decline in leisure is concentrated in the 1990s for Canada and the UK, while for Norway and the Netherlands we find a smooth decline. Leisure remained constant for Australian and French women. Finland is the only country where leisure increased by about 6 hours per week between the 1970s and the 1990s, especially during the 1990s.

Women increased the time devoted to child care and decreased the time devoted to unpaid work in all countries. Child care ranged between 2 hours and 30 minutes and 7 hours per week week in the 1970s, and between 5 and 9 hours per week by the end of the period. Similarly, unpaid work ranged between 29 hours and 37 hours and 30 minutes per week in the 1970s, and between 24 and 31 hours per week by the end of the period. Time devoted to paid work also increased in all countries by an average of 6 hours and 35 minutes per week, except for Finland where paid work declined over the relevant period by 5 hours and 15 minutes per week. ${ }^{6}$ Decreases in unpaid work and leisure financed the increases in the time devoted to paid work and child care in all countries except for Finland. In Canada, the Netherlands, Norway, and the UK, where leisure decreased by 2 hours and 50 minutes per week, the time devoted to paid work and child care increased by 8 hours and 30 minutes, and 1 hour and 15 minutes per week, respectively, while the time devoted to unpaid work decreased by 7 hours and 15 minutes. In Australia and France, where leisure remained constant over this period, the increase in the time devoted to paid work ( 2 hours and 50 minutes per week) and child care ( 1 hour and 15 minutes per week) was entirely financed by the decrease in unpaid work (4 hours and 15 minutes per week). In Finland, the only country with increases in leisure for women, decreases in paid work ( 5 hours and 15 minutes per week) and unpaid work (2 hours and 50 minutes per week) financed the increases in the time devoted to child care ( 1 hour and 50 minutes per week) and leisure (6 hours and 5 minutes per week).

Increases in child care time for men and women in all countries over this period are especially remarkable given the increase in female labor force participation and declines in

\footnotetext{
${ }^{6}$ Finland is the country where women had the highest number of hours devoted to paid work at the beginning of the period.
} 
fertility. Aguiar and Hurst (2007) and some other authors have noted that the increase in the time devoted to parental child care time in the US, especially in recent decades, may be due to changes in survey methodology which has been argued to code as child care more time than in previous surveys (e.g., Bianchi 2000; Ramey and Francis 2009; Guryan, Hurst, and Kearney 2008). The fact that we document generalized parental time increases in most countries suggest that US patterns may be not an artefact of the data, but rather part of a more general trend.

Trends in leisure, paid work, unpaid work, and child care time for men and women are statistically significantly different from each other in all countries. ${ }^{7}$ Additionally, in Table 4 we also analyze to what extent the "iso-work fact" proposed by Burda, Hamermesh and Weil (2008) among others is found for the countries and years studied here. These authors find that the correlation in men's and women's total (paid and unpaid) work is close to one in rich northern countries, indicating similar levels of total work by gender. We follow a similar methodology here and define total work as the sum of the time devoted to paid work, unpaid work, and child care. Because we generally lack information on spouse's time use, a more thorough analysis of household time allocation cannot be done and results presented here are for men and women in different households. Consistent with the evidence presented in Burda et al., we find that in most countries differences in total work are small and seem to have been decreasing over time. In the most recent decades gender differences were the smallest in Canada, Norway, and the UK (less than two hours per week). In Australia, Finland, and France differences were a bit higher, up to four and a half hours per week. Only the Netherlands stands out as the country where men spend between 6 and 7 hours more than women in total work during the 90's and the 00's, although using an older sample as in Burda et al. reduces the difference to about an hour in line again with the iso-work fact. ${ }^{8}$

In interpreting the changes in time use described in this section it is important to have in mind a couple of issues that affect time diary data. First, the main analysis in this paper is for non-retired individuals. However, retirement ages have diminished in all countries and individuals live longer now than before (see Tables E1 and E2 in Appendix E). Thus, the exclusion of retired individuals from our sample may not give a truthful picture of how leisure and other uses of time may have changed over time. Tables E3 and E4 include robustness checks for a sample of retired and non-retired individuals, showing that increases/decreases in

\footnotetext{
${ }^{7}$ Finland and France are exceptions. Leisure (in Finland) and child care (in France) increased for both men and women to the same extent. These statistical tests are based on the difference between the change in the time devoted to a particular activity for men minus the change for women. Results available upon request.

${ }^{8}$ Further investigations suggest that men's paid work is the determinant for the divergence across the different age-samples in the Netherlands. Using an older sample does not substantially change the results for the other countries.
} 
leisure are under/over-estimated when no retirees are included in the sample as expected. Whereas women's use of time is not affected by including retired women in the sample, results for men show larger decreases in paid work, smaller decreases in child care, and larger increases in unpaid work in all countries. Differences by gender may reflect the fact that increases in free time later in the life cycle for women due to increasing retirement ages and longer lifespans over this period have been partially compensated by secular increases in paid work.

Second, vacation time has changed across countries and over time and so the implications about annual leisure time may be different from the implications we draw here, which are mainly concerned with a usual week/or day and not necessarily with yearly variations. Diary data are limited in this respect, as we generally observe only one day per respondent, and normally there is no information in the survey on whether the diarist was on vacation during the diary day or not. Moreover, most surveys are implemented by drawing a household from the population and assigning that household a survey "day of the week" but not a given date, which is particularly problematic for measuring vacation times, given that while a household is on a vacation away from home, it will not be contacted, and thus diary data are likely to underreport vacation days as respondents are less likely to answer the diary when they are on holiday (see Aguiar and Hurst, 2007).

Comparable historical data on vacation time is hard to come by. For the countries we have been able to find vacation time, vacation times in 1954 were 3 weeks in Finland and France, 12 days in the Netherlands, and 6 days/2 weeks for the United Kingdom. In the year 2004 vacation time was 20 working days in Finland, the Netherlands and the United Kingdom, and 25 working days in Australia, France and Norway. In the case of Canada, vacation time was 10 working days per year (see Lee, MacCaan and Messenger (2007)). Thus, given that vacation time has increased over time in most countries, the patterns in leisure we report here may be an underestimation of annual patterns, whereas work patterns reported here may be overestimating yearly work times. It is interesting to see however that whereas the larger increase in annual paid leave is found in the United Kingdom (e.g., from 6 days to 20 working days), and the lowest increase is found in the Netherlands (e.g., from 12 days to 25 working days), we find an increase in the time devoted to paid work in the United Kingdom between the 1970's and the 2000 's, whereas the time devoted to paid work in the Netherlands decreased. Similarly, in the last decade, for which vacation time is readably available, cross-country differences in vacation time are small (about 5 working days per year). These findings suggest that changes in annual paid leave over time and across countries cannot fully account for changes in time allocation decisions reported here. 
Given the large cross-country differences with respect to the number of children (see Table 1), we have also restricted the analysis to individuals with at least 1 child under 5 in the household (see Tables F1 and F2 in Appendix F, not for publication). ${ }^{9}$ As would be expected, the increase in child care for this group is higher than those presented in the paper for the unrestricted sample. Leisure declines in most countries for men in this subsample (the only exception is Finland, although the leisure increase is smaller for this subgroup), and the decrease in leisure is larger for women in this subsample. Trends in paid work and unpaid work for this subsample are similar to the ones presented in the paper. Thus, it seems that there has been a trade-off between leisure and child care for this specific group of the population during this period.

Table 5 shows changes in the time devoted to different leisure activities for men (Panel A) and women (Panel B). ${ }^{10}$ Based on Aguiar and Hurst (2007), we consider the following activity groups: TV watching, sleep (which includes taking naps and sleeping at night), personal care (such as dressing up and grooming activities), gardening and pet care, sports and physical activities (such as walking, hunting, fishing, cycling, weightlifting), eating, reading (magazines, newspapers, etc), socializing (such as visiting friends and having friends over, parties, receptions, restaurants, talking by phone with friends etc), and 'other activities' (e.g., relax, do nothing, gambling, playing an instrument, listen to radio, cinema or theatre).

We show increases in the time spent watching television in most countries with an overall increase of over 3 hours per week for men and women. The only exceptions to this increasing trend are men in the Netherlands, and women in Australia, the Netherlands and the UK. Men and women also increased the time devoted to sports by about 1 hour and 20 minutes in all countries, while the time spent sleeping increased by 1 hour and 45 minutes per week for men, and 2 hours and 5 minutes per week for women in all countries, with the exception of Norway. There is no clear convergence in the cross-country trends for socializing time for either men or women over the relevant period. Men and women experienced a decrease in the time spent eating in most countries by an average of 2 hours per week, with the exception of France where the time devoted to eating increased for both men and women. Men decreased the time spent in reading (by 1 hour and 25 minutes per week, excluding the UK), and personal care (by 1 hour and 55 minutes per week on average, except for Australia and the Netherlands), and women

\footnotetext{
${ }^{9}$ We cannot run the analysis for France as we do not have information on the number of children under 18 in the household for the 1970's.

${ }^{10}$ A p-value lower than 0.05 means that the change has been statistically significant at the $95 \%$ level. Table A3 in Appendix shows the activities included in each component of leisure according to the MTUS classification.
} 
decreased the time spent reading (by 1 hour and 5 minutes per week on average in Australia, France, the Netherlands and the US).

Table 6 explores whether the availability of television channels in the 1990s and the 2000s can explain the allocation of time to watching television. The cross-country correlation between the number of television channels and the time devoted to watching television is close to cero however. In particular, although in the 1990's France and Norway had the highest number of television channels, individuals in other countries (like the UK and Finland) devoted more hours to watch television. Similarly, in The Netherlands and the UK (the only countries for which we have data on both channel availability and time spent watching television for both decades), the spectacular increase in the amount of channels over this period has not been followed by increases in the time watching television. This evidence suggests that at least in the last two decades the availability of television channels cannot explain the increase in the time spent watching television. We still cannot rule out however a positive relationship between these two variables during the earlier decades, especially between the 70s and the 80 s where most of the increase in the time spent watching television occurred. This would be the case if, for example, the marginal increase in the time spent watching television were greater the fewer the number of channels there was. ${ }^{11}$

\section{LEISURE INEQUALITY}

The previous section has documented trends in leisure over the last decades. In this section we consider how the entire leisure distribution has evolved to shed some light onto leisure inequality trends. ${ }^{12}$ We first look at two different moments of the leisure distribution: the Gini index for leisure and the ratio of the 90th percentile and the 10th percentile of leisure, for each country and decade. We also analyze the extent to which leisure has become more unequal between education groups.

Columns (1) to (5) in Panel A and B of Table 7 shows the Gini index for leisure (multiplied by 100) and the ratio of the 90th percentile and the 10th percentile of leisure. The Gini Index

\footnotetext{
${ }^{11}$ To our knowledge there is not data on the availability of television channels for earlier decades that can be readily comparable.

12 Other authors have used other forms of leisure to complement income inequality measures. For example, Sevilla-Sanz, Gimenez-Nadal, and Gershuny (2012) look at the fragmentation of leisure in the US for the period 1965-2003 and report that while highly educated men have experienced a more favorable trend in leisure fragmentation than low educated men, highly educated women have experienced a less favorable trend in leisure fragmentation than their low educated counterparts. In a similar vein, Hamermesh (2005) finds that higher household incomes enable people to purchase more temporal variety, which influences individual well-being since temporal routine is boring and undesirable.
} 
ranges from 0 to 100. A low Gini index indicates a more disperse leisure distribution, with 0 corresponding to complete equality (e.g., all the individuals have the same amount of leisure), and 100 corresponding to complete inequality. According to both measures, the dispersion of the distribution of leisure steadily increased in all countries over the relevant period, which means that adults with the highest level of leisure at the beginning of the period increased their relative leisure time compared to adults with the lowest level of leisure time at the beginning of the period. The Netherlands and Canada are the countries that experienced the greatest increase in the dispersion of the leisure distribution. In the Netherlands, the increase in the Gini index was 7.15 , and the increase in the 90th to 10 th percentile ratio was 0.60 , which correspond to an increase in the difference of leisure time favoring the 90th percentile of 40 hours per week between the 1970s and the 2000s (i.e., from 101.50 and 133.25 hours per week for the $10^{\text {th }}$ and $90^{\text {th }}$ percentile in the 1970 s, to 78.75 and 150.5 hours per week for the $10^{\text {th }}$ and $90^{\text {th }}$ percentile in the 2000s, respectively). In Canada, the corresponding increases were 2.50 for the Gini index and 0.27 for the 90 to 10 percentile ratio, which corresponds to an increase in the difference of leisure time favoring the 90th percentile of 14 hours per week between the 1970s and the 1990s (i.e., i.e., from 78.12 and 141.75 hours per week for the $10^{\text {th }}$ and $90^{\text {th }}$ percentile in the 1970 s, to 71.75 and 149.33 hours per week for the $10^{\text {th }}$ and $90^{\text {th }}$ percentile in the $1990 \mathrm{~s}$, respectively). France and Finland are the countries that experienced the smallest increases in the dispersion of the leisure distribution. The Gini index increased 0.29 in France, and 0.70 in Finland, whereas the 90 to 10 percentile increased by .01 in France (i.e., an increase in the difference of leisure time over the analyzed period favoring the 90th percentile of 45 minutes), and .07 in Finland (i.e., an increase favoring the 90th percentile of 5 hours and 50 minutes per week).

The greater dispersion in the leisure distribution documented in Table 7 coincides with the greater dispersion in income and earnings documented for most countries over this period. ${ }^{13}$ Columns (1) to (5) in Panel A and B of Table 8 show the Gini Index for income (multiplied by 100 ) and the $90^{\text {th }}$ to $10^{\text {th }}$ percentile ratio for earnings, for each country and decade. ${ }^{14}$ According to both indicators, the dispersion in the income and earnings distributions increased in all

13 These results are consistent with those in the literature (see Atkinson (2007), Acemoglu (2003), Alderson and Nielsen (2002), Atkinson and Brandolini (2001), Gustafsson and Johansson (1999), and Gottschalk and Smeeding (1997) for cross-country comparisons of income inequality in OECD countries over this period).

${ }^{14}$ We take the Gini Index for income from the 'University of Texas Inequality Project', based on the World Bank Dataset (www.worldbank.org). Data are based on primary household survey data obtained from government statistical agencies and World Bank country departments. Data for high-income economies are from the Luxembourg Income Study database. We calculate the 90 to 10 earnings percentile ratio using the 90 and 10 earnings percentiles from the OECD Earnings database (stats.oecd.org). The ninth and first deciles are upper-earnings decile limits, unless otherwise indicated, of gross earnings of full-time dependent employees. 
countries, with the exception of Finland and France which, as in the case of leisure, show the smallest increase in the dispersion of the income and earnings the distributions according to the Gini index and a decrease in the dispersion of the distributions according to the 90 to 10 percentile ratio.

Tables 9 reports the demographically adjusted time spent in leisure for men and women, broken down by educational attainment. We use three harmonized education categories: less than high school diploma ( $<12$ years of schooling), high school diploma (12 years of schooling), and some college or more ( $>12$ years of schooling). We focus on differences in leisure time between individuals with less than high school (low educated individuals), and individuals with some college/college graduates (highly-educated individuals).

In most countries except for Norway, differences in the change of leisure time between low and highly educated adults increased over this period in favour of the less educated. In the United Kingdom leisure increased relatively more for men with less than a high school degree (by about 4 hours per week) relatively to men with some college or more (who experienced increases of half an hour per week). Similar trends are found in Australia and Finland, although these trends across educational groups are not significantly different from each other. In the Netherlands - where leisure decreased - leisure decreased relatively more for highly educated men (by 7 hours and 30 minutes per week) than for high school drop outs (by 2 hours and 40 minutes per week). Men with less than a high school diploma in Canada and France experienced an increase in leisure, while men with some college or more experienced a decrease in leisure. In Norway leisure decreased for both educational groups, albeit more for men with less than a high school diploma (these trends are however not significantly different from each other at standard significant levels). Women with less than a high school diploma in Canada, France and Norway experienced an increase in leisure, while women with some college or more experienced a decrease in leisure. In the Netherlands - where leisure decreased- leisure decreased relatively more for highly educated women (by 5 hours and 45 minutes per week) than for high school drop outs (2 hours per week). In Australia, Finland and the United Kingdom the difference in the changes over the period between the two educational groups is not statistically significant, although the figures indicate relative gains of leisure for less educated women in Australia and the United Kingdom.

The widespread increase in leisure inequality favoring the less educated documented in Table 9 mirrors the general increase in income and earnings inequality favoring highly-educated individuals experienced in most countries over this period, especially after the 1980s. As reported by Aguiar and Hurst (2007), who document that the timing of the changing inequality in leisure across education groups coincided with the timing of the changing inequality in wages 
and consumption for the case of the United States. Table 9 shows that most of the divergence in leisure time for both men and women is concentrated in the middle of the period, particularly in the 1980s and 1990s, and coincides with the well-documented change in wages and consumption between education groups in these countries in recent decades. ${ }^{15}$ In contrast to income inequality however, which favored highly educated individuals, the increase in leisure inequality favored the less educated.

Although it would be interesting to see to what extent differences in wage inequality can explain cross-country differences in leisure inequality trends, more explicit comparisons between the divergence in leisure time and the divergence in wages and consumption by education are not possible because we do not have information on individual wages or personal income. We have information on total household income however, although it is recorded in brackets and is thus not ideal to quantify to what extent different trends in income inequality can explain cross-country differences in leisure inequality trends. ${ }^{16}$ Instead, we look at correlations between total household income and individual leisure time. Table 10 shows that these correlations are strongly negative in all years and countries. Moreover, to the extent that higher levels of household income is related to higher levels of education, the fact that we find that the negative income-leisure correlation is larger in absolute values during the later decades is in line with the increase in leisure inequality by education level during the 1980's and 1990's documented above.

Tables 11 to 13 show the drivers behind the increase in the education gap in leisure time over this period. Table 11 shows that the divergence in leisure for both men and women is due primarily to differences in paid work. In most countries, paid work hours fell by a much greater degree for less-educated men ( 8 hours and 15 minutes per week on average) than for highlyeducated men ( 2 hours and 50 minutes per week on average). In fact, paid work hours increased for men with some college or more in France (1 hour and 45 minutes per week), and the Netherlands (4 hours and 35 minutes per week). For women however, high school dropouts experienced an increase of 50 minutes per week on average in paid work, whereas women with some college or more experienced a much greater increase (of 5 hours per week on average).

15 See Freeman and Katz (1995), and Katz and Autor (1999) for a cross-country comparison of the college wage premium over this period. For more country-specific account, see Boudarbat et al. (2010) and Brzozowski et al. (2009) for Canada, Eriksson and Jäntii (1997) for Finland, Katz and Autor (1999) and Freeman and Katz (1995) for France and the Netherlands, Hægeland et al. (1999) for Norway, and Machin (1997) and Gosling, Machin and Meghir (2000) for the UK.

16 The only surveys where we have continuous information for income are The Netherlands in 2000, Norway in 1990 and 2000, the United Kingdom in 1987, Finland in 1999, and Australia in 1997. 
The only exceptions to this trend are men and women in Norway, men in Australia and Finland, and women in Canada. ${ }^{17}$

Despite overall increases in child care over the male education distribution, neither child care nor unpaid work contributed to the divergence across education groups in leisure for men. Child care increased more for men with some college or more than for high school dropouts in most countries, although only for the United Kingdom such difference is statistically significant at the 95\% level. Similarly, changes in unpaid work for less and highly educated men were not statistically significant different from each other. Unpaid work increased relatively more for men with some college or more in Finland (a difference of 2 hours and 45 minutes per week favouring the highly educated men), and increased less in the Netherlands and the UK (by an average of 4 hours and 45 minutes per week for the highly-educated versus 7 hours and 20 minutes per week for less-educated men).

The variation of child care and unpaid work time across education groups over this period is much more uniform across countries for women than for men. Highly-educated women in Canada, Norway and the UK experienced an increase in child care time of 1 hour and 50 minutes per week on average, versus just 30 minutes per week for less-educated women (less educated women in Norway actually decreased child care time by 1 hours and 25 minutes per week). In contrast, in Australia, Finland and France women with some college or more experienced a smaller increase (or even a decrease) in child care time (increase of 2 hours per week on average) with respect to less-educated women (who experienced an increase of 5 minutes per week on average), although differential trends are not significantly different. Unpaid work time decreased relatively more for women with some college or more in Australia, the Netherlands and the United Kingdom (by an average of 8 hours and 15 minutes per week for the highly-educated versus 1 hour and 55 minutes per week for less-educated women). In Canada and Norway, unpaid work decreased less for highly educated women (by an average of 2 hours and 15 minutes per week for the highly-educated versus 5 hours and 30 minutes per week for less-educated women). In Finland unpaid work increased for women with less than a high school diploma, while it increased for highly educated women.

Tables 14 and 15 explore how the time devoted to different leisure activities has evolved for individuals with different educational attainment. There are not many common patterns between

\footnotetext{
${ }^{17}$ The relative gains in leisure time for individuals with less than a high school diploma continues to hold even after conditioning on employment. Tables D1 and D2 in Appendix D show that the same differential trends are observed among working individuals, which suggests that the relative gains in leisure for the less educated is not a result of these individuals opting out of the labor market, and may reflect heterogeneity in preferences as well as exogenous market forces..
} 
educational groups in the evolution of the time spent in different leisure activities across countries. The only activity that stands out is socializing. Although the time spent socializing decreased in some countries and increased in others, it seems that in those countries where the time spent in socializing activities increased, it increased more for high-school drop outs, and in those countries where the time spent socializing decreased, it decreased more for individuals with at least some college. To the extent that spending leisure time socializing with other adults is more pleasurable than other leisure activities (Sevilla-Sanz, Gimenez-Nadal and Gershuny 2011; Kahneman et al. 2004; Robinson and Godbey 1999), college educated individuals may have not only decreased the quantity of leisure time with respect to less educated adults, but also their quality may have relatively suffered. Unlike in the United States, where low educated individuals experienced a relative increase in the time spent watching television, there are no clear patterns in the differences between educational groups with respect to the time spent watching television, especially for men. In Australia, Norway, and the United Kingdom highly educated men and women experienced an increase of 2 hours on average on the amount of time spent watching television, whereas men and women with less than a high school qualification experienced a lower increase of 1 hour and 10 minutes per week. In contrast, the increase in the time spent watching television was greater for high school drop-outs than for adults with some college degree or more in Canada, Finland and France.

\section{CONCLUSIONS}

This paper has first looked at the trends in the allocation of time from the1970s until today for seven industrialized countries. Men and women devote a considerable amount of time to household production activities and child care. Moreover, the time devoted to these activities has substantially changed over the years. Men increased the time spent in household chores, whereas women decreased the time devoted to unpaid home activities, and despite falling fertility rates the time spent caring for children increased in most countries over the period. Increases in unpaid labor and child care were mostly financed by declines in paid work for men, whereas declines in unpaid work (and to a lesser extent leisure) financed the increase in the time devoted to paid work and child care for women. In contrast to the documented increase in leisure for men and women in the US over the same period, we find different leisure trends across countries for men, and document a generalized decline in leisure time for women in all but one of the industrialized countries considered.

As in the US, increases in women's paid work were mostly financed by decreases in unpaid work. We also document similar total workloads (paid and unpaid work) for men and women, 
which may explain why the decline in women's unpaid work was not compensated by similar increases in men's unpaid work time. This evidence suggests that households probably increased the outsourcing of household services to the market as well as reduced the amount of goods and services provided within the home. Further increases in female labor force participation may thus depend on the degree of substitution between goods and time in housework activities. Some authors have argued that the extent to which market and home produced goods and services can be substitutes for one another may lie in technological factors (see Greenwood et al., 2005 for an analysis of how the introduction of labor-saving consumer durables -such as washing machines- liberated women from chores and expanded their labor market participation in the 70s). Under no further technological innovations, gender based taxation schemes with a higher marginal tax rates on men have been recently proposed as a way to achieve a more balanced allocation of labor market outcomes between men and women (see Alesina et al., 2011). In turn, our findings highlight the need for a proper characterization of non-market work beyond leisure to properly understand female labor force participation decisions.

In line with US findings, we also document an increase in the dispersion in the leisure distribution in all countries, especially after the 1980s. Similarly, leisure time increased relatively more for high school drop outs relatively to adults with some college or more in those countries where leisure increased, and decreased relatively less in those countries where leisure decreased. The increase in leisure inequality in favour of less educated adults was due primarily to differences in paid work, and it mirrored the general increase in income and earnings inequality experienced in most countries over this period. Thus, unlike what happened in the US, the cross-sectional and time series evidence presented in this paper suggest that, for the most part, higher incomes have become increasingly associated with less leisure time.

The universal increases in leisure inequality found here crucially inform a recent broadening of focus from production to the measurement of well-being. Stiglitz, Sen and Fitoussi (2009) among others have recently proposed a broad range of measures of household economic activity to evaluate quality of life, including time spent in leisure activities. The fact that we find that differences in leisure across the education distribution are due primarily to differences in paid work, as opposed to unpaid work, suggests that the relative decrease of expenditure for the less educated may have resulted in lower consumption levels as they did not produce in the household the goods and services acquired in the market by the high-educated. To the extent that leisure time has value (as studies measuring instant satisfaction have shown, i.e., Kahneman and Krueger, 2006), the evidence presented in this paper may provide a promising line of research for understanding income inequality and for interpreting the decline in relative wages 
and expenditure that has been documented in most countries in light of the simultaneous relative growth of leisure for the less educated.

\section{REFERENCES}

Acemoglu, D. (2003). "Cross-Country Inequality Trends," Economic Journal, 113, F121- F149

Aguiar, M., and E. Hurst (2007). "Measuring Trends in Leisure: The Allocation of Time over Five Decades," Quarterly Journal of Economics, 115, 969-1006.

(2009). “A Summary of Trends in American Time Allocation: 1965-2005," Social Indicators Research, 93, 57-64.

Alderson. A.S., and F. Nielsen (2002). "Globalization and the Great U-Turn: Income Inequality Trends in 16 OECD Countries," American Journal of Sociology, 107, 1244-1299.

Alesina, A., A. Ichino and L. Karabarbounis. (2011). "Gender-Based Taxation and the Division of Family Chores," American Economic Journal: Economic Policy, 3, 1-40.

Atkinson, A.B., and A. Brandolini (2001). "Promise and Pitfalls in the Use of "Secondary" Data-Sets: Income Inequality in OECD Countries As a Case Study," Journal of Economic Literature, 39, 771-799.

Atkinson, T., (2007). "The distribution of earnings in OECD countries," International Labor Review, 146, 41-6

Bianchi, S.M. (2000). "Maternal employment and Time with Children: Dramatic Change or Surprising Continuity?” Demography, 37, 401-414.

Biddle, J., and D. Hamermesh (1990). "Sleep and the Allocation of Time," Journal of Political Economy, 98, 922-943.

Boudarbat, B., T. Lemieux and W.C Ridell (2010). "The Evolution of the Returns to Human Capital in Canada, 1980-2005," Canadian Public Policy, 36, 63-89.

Brzozowski, M., M. Gervais, P. Klein and M. Suzuki (2010). "Consumption, income, and wealth inequality in Canada," Review of Economic Dynamics, 13, 52-75. 
Budig, M. J., and N. Folbre (2004). "Activity, Proximity, or Responsibility? Measuring Parental child care Time," in Family Time: The Social Organization of Care, Folbre and Bittman (eds.), New York: Routledge.

Burda, M., D. Hamermesh and P. Weil (2008). "The Distribution of Total Work in the US and EU," in Working Hours and Job Sharing in the EU and USA: Are Americans Crazy? Are Europeans Lazy? Boeri, Burda and Kramarz (eds.), Oxford Univ. Press.

CIA World Factbook, The, Central Intelligence Agency, http://www.cia.gov/library/publications/the-world-factbook/

Eriksson, T., and M. Jäntii (1997). "The distribution of earnings in Finland 1971-1990," European Economic Review, 41, 1763-1779.

Fhar, R. (2005). "Loafting or learning?-the demand for informal education," European Economic Review, 49, 75-98.

Fisher, K., M. Egerton, J. Gershuny, and J. Robinson (2007). "Gender Convergence in the American Heritage Time Use Study," Social Indicators Research, 82, 1-33.

Folbre, N., and M. Bittman (2004). Family Time: The Social Organization of Care (Routledge, New York, NY).

Freeman, R., and L.F. Katz (1995). Differences and Changes in Wage Structure (University of Chicago Press and NBER)

Gauthier, A., T.M. Smmeding and F.F.J. Furstenberg (2004). "Are parents investing less in children? Trends in selected industrialized countries," Population and Development Review, 30, 647-671.

Ghez, G., and G. S. Becker (1975). The Allocation of Time and Goods over the Life Cycle. New York: Columbia University Press.

Gershuny, J.I. (2009a). "Veblen in Reverse: Evidence from the Multinational Time-Use Archive," Social Indicators Research, 93, 37-45.

(2009b). "Activities, durations, and the empirical estimation of utility," Oxford Sociology Working Paper N 2009-07.

Gosling, A., S. Machin and C. Meghir (2000). "The changing distribution of male wages in the U.K." Review of Economic Studies, 67, 635-666. 
Gottschalk, P., and T.M. Smeeding (1997). "Cross-national comparisons of earnings and income inequality," Journal of Economic Literature, 35, 633-687.

Greenwood, J., A. Seshadri and M. Yorukoglu (2005) "Engines of Liberation," The Review of Economic Studies, 72(1), 109-133.

Guryan, J., E. Hurst, and M. Kearney (2008). "Parental Education and Parental Time with Children," Journal of Economic Perspectives, 22, 23-46.

Gustafsson, B., and M. Johansson (1999). "In search of smoking guns: What makes income inequality vary over time in different countries?" American Sociological Review, 64, 585-605.

Hægeland, T., T.J. Klette and K.G. Salvanes (1999). "Declining returns to education in Norway? Comparing estimates across cohorts, sectors and over time," Scandinavian Journal of Economics, 101, 555-576.

Hamermesh, D. (2005). "Routine,” European Economic Review, 49, 29-5.

Hamermesh, D., and G. A. Pfann (2005). "Time-use data in economics," European Economic Review, 49, 1-7.

Hamermesh, D., and J. Lee (2007). "Stressed Out in Four Continents: Time Crunch or Yuppie Kvetch?” Review of Economics and Statistics, 89, 374-383.

Hook, J.L. (2006). "Care in Context: Men's Unpaid Work in 20 Countries, 19652003," American Sociological Review, 71, 639-60.

Jacobsen, J. P., and P. Kooreman (2005). "Timing constraints and the allocation of time: The effects of changing shopping hours regulations in The Netherland," European Economic Review, 49, 9-27.

Juster, T., and F. Stafford (1985). Time, Goods, and Well-Being (Ann Arbor: Institute for Social Research, The University of Michigan).

Katz, L., and K. Murphy (1992). "Changes in Relative Wages, 1963-1987: Supply and Demand Factors," Quarterly Journal of Economics, 107, 35-78.

Kahneman, D., A.B. Krueger, D. Schkade, N. Schwarz, and A. Stone (2004). "A Survey Method for Characterizing Daily Life Experience: The Day Reconstruction Method," Science, 3, 1776-1780. 
Kahneman, D., and A.B. Krueger (2006). "Developments in the Measurement of Subjective Well-Being,” Journal of Economic Perspectives, 20, 3-24.

Katz, L. F., and D.H. Autor (1999). "Changes in the Wage Structure and Earnings Inequality," in Handbook of Labor Economics, vol. 3A, Ashenfelter and Card (eds.), Oxford: Elsevier Science.

Klevmarken, N.A. (2005). "Estimates of a labour supply function using alternative measures of hours of work," European Economic Review, 49, 55-73.

Kooreman, P., and A. Kapteyn (1987). "A Dissagregated Analysis of the Allocation of Time within the Household," Journal of Political Economy, 95, 223-249.

Krueger, A.B., (2007). "Are We Having More Fun Yet? Categorizing and Evaluating Changes in Time Allocation," Brooking Papers on Economic Activity, 2, 193-217.

Lee, S., D. McCaan and J.C. Messenger. (2007). Working Time Around the World: Trends in working hours, laws and policies in a global comparative perspective, International Labour Office, Routledge, Taylor and Francis.

Machin, S. (1997). "The decline of labour market institutions and the rise in wage inequality in Britain," European Economic Review, 41, 647-657.

MAVISE, Database on TV companies and TV channels in the European Union and candidate countries, http://mavise.obs.coe.int

Multinational Time Use Study, Version W553, http://www.timeuse.org/mtus/

OCDE (2011a). “OCDE Health Data 2011,” Directorate for Employment, Labour and Social Affairs, OCDE. http://www.oecd.org/document/16/0,3343,en_2649_34631_2085200_1_1_1_1,00.ht $\underline{\mathrm{ml}}$

OCDE (2011b). "Statistics on average effective age and official age of retirement in OECD countries," Directorate for Employment, Labour and Social Affairs, OCDE. http://www.oecd.org/document/47/0,3343,en_2649_34747_39371887_1_1_1_1,00.h $\underline{\mathrm{tml}}$

Ramey, V., and N. Francis (2009). "A Century of Work and Leisure," American Economic Journal: Macroeconomics, 1, 189-224. 
Robinson, J. P., and G. Godbey (1985). Time For Life: The Surprising Ways Americans Use Their Time (University Park, Pennsylvania: Penn State University Press). (1999). Time for Life: the Surprising Ways Americans Use Their Time. University Park, PA: Pennsylvania State University Press, second edition.

Sevilla-Sanz,. A., J.I. Gimenez-Nadal, and J.I. Gershuny (2012). Leisure inequality in the US: 1965-2003," Demography (DOI: 10.1007/s13524-012-0100-5)

Stiglitz, J., A. Sen and and J-P. Fitoussi (2009) Report by the Commission on the Measurement of Economic Performance and Social Progress. 
Table 1. Summary Statistics of main demographic characteristics

\begin{tabular}{|c|c|c|c|c|c|c|c|c|c|c|c|c|c|c|c|}
\hline & Male & $\begin{array}{c}\text { Age 21- } \\
29\end{array}$ & $\begin{array}{c}\text { Age 30- } \\
39\end{array}$ & $\begin{array}{c}\text { Age 40- } \\
49\end{array}$ & $\begin{array}{c}\text { Age 50- } \\
59\end{array}$ & $\begin{array}{c}\text { Age 60- } \\
65\end{array}$ & $\begin{array}{l}\text { Some college } \\
\text { and college } \\
\text { grads }\end{array}$ & $\begin{array}{l}\text { High-school } \\
\text { diploma }\end{array}$ & $\begin{array}{c}\text { Less than } \\
\text { high-school }\end{array}$ & Married & $\begin{array}{l}\text { Have } \\
\text { Child }\end{array}$ & $\begin{array}{c}\text { Number } \\
\text { of } \\
\text { Children }\end{array}$ & $\begin{array}{l}\text { Presence of } \\
\text { children }<5\end{array}$ & Employed & $\begin{array}{l}\text { Sample } \\
\text { Size }\end{array}$ \\
\hline \multirow[t]{2}{*}{ Australia } & 49.24 & 21.54 & 28.26 & 25.78 & 18.94 & 5.48 & 27.90 & 36.31 & 35.79 & 75.38 & 49.20 & 0.96 & 20.90 & 74.20 & 21,844 \\
\hline & $(0.35)$ & $(0.29)$ & $(0.31)$ & $(0.30)$ & $(0.27)$ & $(0.15)$ & $(0.31)$ & $(0.33)$ & $(0.33)$ & $(0.30)$ & $(0.35)$ & $(0.01)$ & $(0.28)$ & $(0.30)$ & \\
\hline \multirow[t]{2}{*}{ Canada } & 49.37 & 24.83 & 30.15 & 24.01 & 16.23 & 4.79 & 48.61 & 23.55 & 27.84 & 72.77 & 47.37 & 0.89 & 18.90 & 74.35 & 47,270 \\
\hline & $(0.29)$ & $(0.24)$ & $(0.25)$ & $(0.25)$ & $(0.23)$ & $(0.13)$ & $(0.29)$ & $(0.24)$ & $(0.26)$ & $(0.25)$ & $(0.28)$ & $(0.01)$ & $(0.21)$ & $(0.25)$ & \\
\hline \multirow[t]{2}{*}{ Finland } & 49.49 & 20.05 & 28.95 & 24.96 & 20.55 & 5.48 & 13.26 & 23.42 & 63.32 & 76.20 & 46.88 & 0.83 & 17.48 & 84.11 & 23,979 \\
\hline & $(0.36)$ & $(0.28)$ & $(0.33)$ & $(0.31)$ & $(0.29)$ & $(0.17)$ & $(0.25)$ & $(0.30)$ & $(0.35)$ & $(0.33)$ & $(0.36)$ & $(0.01)$ & $(0.27)$ & $(0.27)$ & \\
\hline \multirow[t]{2}{*}{ France } & 49.01 & 20.46 & 27.70 & 28.68 & 21.11 & 2.05 & 29.72 & 44.01 & 26.28 & 77.11 & 49.62 & 0.96 & 12.04 & 75.11 & 25,919 \\
\hline & $(0.33)$ & $(0.27)$ & $(0.29)$ & $(0.29)$ & $(0.27)$ & $(0.09)$ & $(0.30)$ & $(0.32)$ & $(0.29)$ & $(0.28)$ & $(0.38)$ & $(0.01)$ & $(0.21)$ & $(0.29)$ & \\
\hline \multirow[t]{2}{*}{ The Netherlands } & 45.10 & 19.61 & 28.71 & 25.13 & 20.80 & 5.76 & 28.25 & 32.65 & 39.10 & 78.41 & 53.21 & 1.06 & 30.07 & 68.75 & 37,964 \\
\hline & $(0.30)$ & $(0.24)$ & $(0.25)$ & $(0.26)$ & $(0.25)$ & $(0.14)$ & $(0.26)$ & $(0.27)$ & $(0.29)$ & $(0.25)$ & $(0.29)$ & $(0.01)$ & $(0.27)$ & $(0.27)$ & \\
\hline \multirow[t]{2}{*}{ Norway } & 51.47 & 23.35 & 25.68 & 22.87 & 20.33 & 7.78 & 24.93 & 45.05 & 30.02 & 79.93 & 56.48 & 1.09 & 23.39 & 82.33 & 31,585 \\
\hline & $(0.29)$ & $(0.25)$ & $(0.25)$ & $(0.24)$ & $(0.23)$ & $(0.16)$ & $(0.30)$ & $(0.35)$ & $(0.32)$ & $(0.23)$ & $(0.29)$ & $(0.01)$ & $(0.24)$ & $(0.22)$ & \\
\hline \multirow[t]{2}{*}{ The United Kingdom } & 50.11 & 24.77 & 25.00 & 22.49 & 20.43 & 7.31 & 20.13 & 31.18 & 48.69 & 77.07 & 47.49 & 0.89 & 19.15 & 75.17 & 31,568 \\
\hline & $(0.31)$ & $(0.28)$ & $(0.26)$ & $(0.25)$ & $(0.24)$ & $(0.24)$ & $(0.24)$ & $(0.30)$ & $(0.31)$ & $(0.27)$ & $(0.31)$ & $(0.01)$ & $(0.24)$ & $(0.28)$ & \\
\hline
\end{tabular}

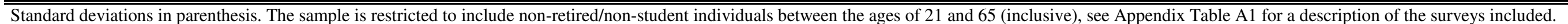


Table 2. Trends in leisure, paid work, unpaid work, and child care (men)

\begin{tabular}{|c|c|c|c|c|c|c|c|c|c|c|}
\hline $\begin{array}{l}\text { Time-use category } \\
\text { (hours per week) } \\
\end{array}$ & \multicolumn{2}{|c|}{ DECADE 70's } & DEC & 80 's & \multicolumn{2}{|c|}{ DECADE 90's } & \multicolumn{2}{|c|}{ DECADE 00's } & \multirow[t]{2}{*}{ Diff. } & \multirow[t]{2}{*}{ P-Value } \\
\hline \multicolumn{9}{|c|}{ Panel A: Leisure } & & \\
\hline & $\underline{\text { Mean }}$ & $\underline{\text { SD }}$ & Mean & $\underline{\text { SD }}$ & $\underline{\text { Mean }}$ & $\underline{\text { SD }}$ & Mean & $\underline{\text { SD }}$ & & \\
\hline Australia & 103.45 & $(1.30)$ & 103.50 & $(0.90)$ & 106.60 & $(0.35)$ & - & - & 3.15 & $(0.02)$ \\
\hline Canada & 105.45 & $(0.77)$ & 106.51 & $(0.36)$ & 105.68 & $(0.32)$ & - & - & 0.23 & $(0.78)$ \\
\hline Finland & 111.61 & $(0.50)$ & 111.13 & $(0.49)$ & 117.79 & $(0.68)$ & - & - & 6.19 & $(<0.01)$ \\
\hline France & 114.09 & $(0.65)$ & - & - & 110.12 & $(0.38)$ & - & - & -3.97 & $(<0.01)$ \\
\hline The Netherlands & 114.15 & $(0.73)$ & 112.79 & $(0.30)$ & 108.53 & $(0.26)$ & 106.47 & $(0.35)$ & -7.68 & $(<0.01)$ \\
\hline Norway & 108.35 & $(0.45)$ & 109.81 & $(0.48)$ & 107.79 & $(0.49)$ & 105.46 & $(0.67)$ & -2.89 & $(<0.01)$ \\
\hline The United Kingdom & 111.59 & $(0.44)$ & 113.52 & $(0.45)$ & 116.12 & $(1.38)$ & 114.54 & $(0.46)$ & 2.95 & $(<0.01)$ \\
\hline \multicolumn{11}{|c|}{ Panel B: Paid work } \\
\hline & $\underline{\text { Mean }}$ & $\underline{\text { SD }}$ & Mean & $\underline{\text { SD }}$ & Mean & $\underline{\text { SD }}$ & $\underline{\text { Mean }}$ & $\underline{\text { SD }}$ & & \\
\hline Australia & 53.01 & $(1.49)$ & 50.16 & $(1.09)$ & 43.95 & $(0.41)$ & - & - & -9.06 & $(<0.01)$ \\
\hline Canada & 47.39 & $(0.88)$ & 44.48 & $(0.42)$ & 44.06 & $(0.37)$ & - & - & -3.33 & $(<0.01)$ \\
\hline Finland & 39.46 & $(0.56)$ & 39.29 & $(0.56)$ & 30.83 & $(0.76)$ & - & - & -8.62 & $(<0.01)$ \\
\hline France & 40.44 & $(0.75)$ & - & - & 41.94 & $(0.45)$ & - & - & 1.50 & $(0.08)$ \\
\hline The Netherlands & 39.37 & $(0.84)$ & 38.25 & $(0.36)$ & 41.91 & $(0.32)$ & 43.36 & $(0.42)$ & 3.98 & $(<0.01)$ \\
\hline Norway & 45.36 & $(0.52)$ & 42.08 & $(0.54)$ & 41.80 & $(0.55)$ & 40.76 & $(0.79)$ & -4.60 & $(<0.01)$ \\
\hline The United Kingdom & 47.14 & $(0.51)$ & 38.30 & $(0.53)$ & 37.10 & $(1.49)$ & 34.05 & $(0.53)$ & -13.10 & $(<0.01)$ \\
\hline \multicolumn{11}{|c|}{ Panel C: Unpaid work } \\
\hline & Mean & $\underline{\text { SD }}$ & Mean & $\underline{\text { SD }}$ & Mean & $\underline{\text { SD }}$ & Mean & $\underline{\text { SD }}$ & & \\
\hline Australia & 9.61 & $(0.59)$ & 11.40 & $(0.43)$ & 13.40 & $(0.18)$ & - & - & 3.79 & $(<0.01)$ \\
\hline Canada & 12.30 & $(0.39)$ & 13.79 & $(0.21)$ & 14.29 & $(0.17)$ & - & - & 1.99 & $(<0.01)$ \\
\hline Finland & 14.50 & $(0.28)$ & 15.43 & $(0.25)$ & 16.06 & $(0.37)$ & - & - & 1.56 & $(<0.01)$ \\
\hline France & 11.48 & $(0.27)$ & - & - & 12.62 & $(0.19)$ & - & - & 1.14 & $(<0.01)$ \\
\hline The Netherlands & 10.39 & $(0.42)$ & 12.95 & $(0.19)$ & 13.32 & $(0.18)$ & 13.33 & $(0.18)$ & 2.94 & $(<0.01)$ \\
\hline Norway & 11.47 & $(0.24)$ & 12.28 & $(0.24)$ & 14.38 & $(0.24)$ & 16.75 & $(0.38)$ & 5.28 & $(<0.01)$ \\
\hline The United Kingdom & 7.65 & $(0.20)$ & 13.69 & $(0.23)$ & 10.83 & $(0.70)$ & 16.15 & $(0.25)$ & 8.50 & $(<0.01)$ \\
\hline \multicolumn{11}{|c|}{ Panel D: Child Care } \\
\hline & Mean & $\underline{\text { SD }}$ & Mean & $\underline{\text { SD }}$ & Mean & $\underline{\text { SD }}$ & $\underline{\text { Mean }}$ & $\underline{\text { SD }}$ & & \\
\hline Australia & 1.52 & $(0.20)$ & 2.12 & $(0.16)$ & 2.44 & $(0.08)$ & - & - & 0.92 & $(<0.01)$ \\
\hline Canada & 1.64 & $(0.13)$ & 2.07 & $(0.07)$ & 2.82 & $(0.07)$ & - & - & 1.18 & $(<0.01)$ \\
\hline Finland & 1.02 & $(0.06)$ & 1.09 & $(0.06)$ & 1.96 & $(0.13)$ & - & - & 0.94 & $(<0.01)$ \\
\hline France & 1.45 & $(0.08)$ & - & - & 1.91 & $(0.06)$ & - & - & 0.46 & $(<0.01)$ \\
\hline The Netherlands & 2.05 & $(0.15)$ & 2.19 & $(0.07)$ & 2.66 & $(0.09)$ & 2.71 & $(0.08)$ & 0.66 & $(<0.01)$ \\
\hline Norway & 1.77 & $(0.07)$ & 2.73 & $(0.10)$ & 3.13 & $(0.12)$ & 3.34 & $(0.17)$ & 1.57 & $(<0.01)$ \\
\hline The United Kingdom & 0.67 & $(0.04)$ & 1.67 & $(0.07)$ & 2.70 & $(0.41)$ & 2.11 & $(0.09)$ & 1.44 & $(<0.01)$ \\
\hline
\end{tabular}

Standard deviations in parenthesis. The sample is restricted to include non-retired/non-student individuals between the ages of 21 and 65 (inclusive), see Appendix Table A1 for a description of the surveys included. Leisure, paid work, unpaid work and child care are measured in hours per week, see Table Appendix A2 for definitions of time-use categories. Demographic weighting proposed by Katz and Murphy (1992) and used by Aguiar and Hurst (2007) are used to ensure a constant representation of types of individuals and days of the week. $\mathrm{T}_{\mathrm{i}}$ is Decade 2000's for the Netherlands, Norway and the United Kingdom, and Decade 1990's for Australia, Canada, Finland and France. 
Table 3. Trends in leisure, paid work, unpaid work, and child care (women)

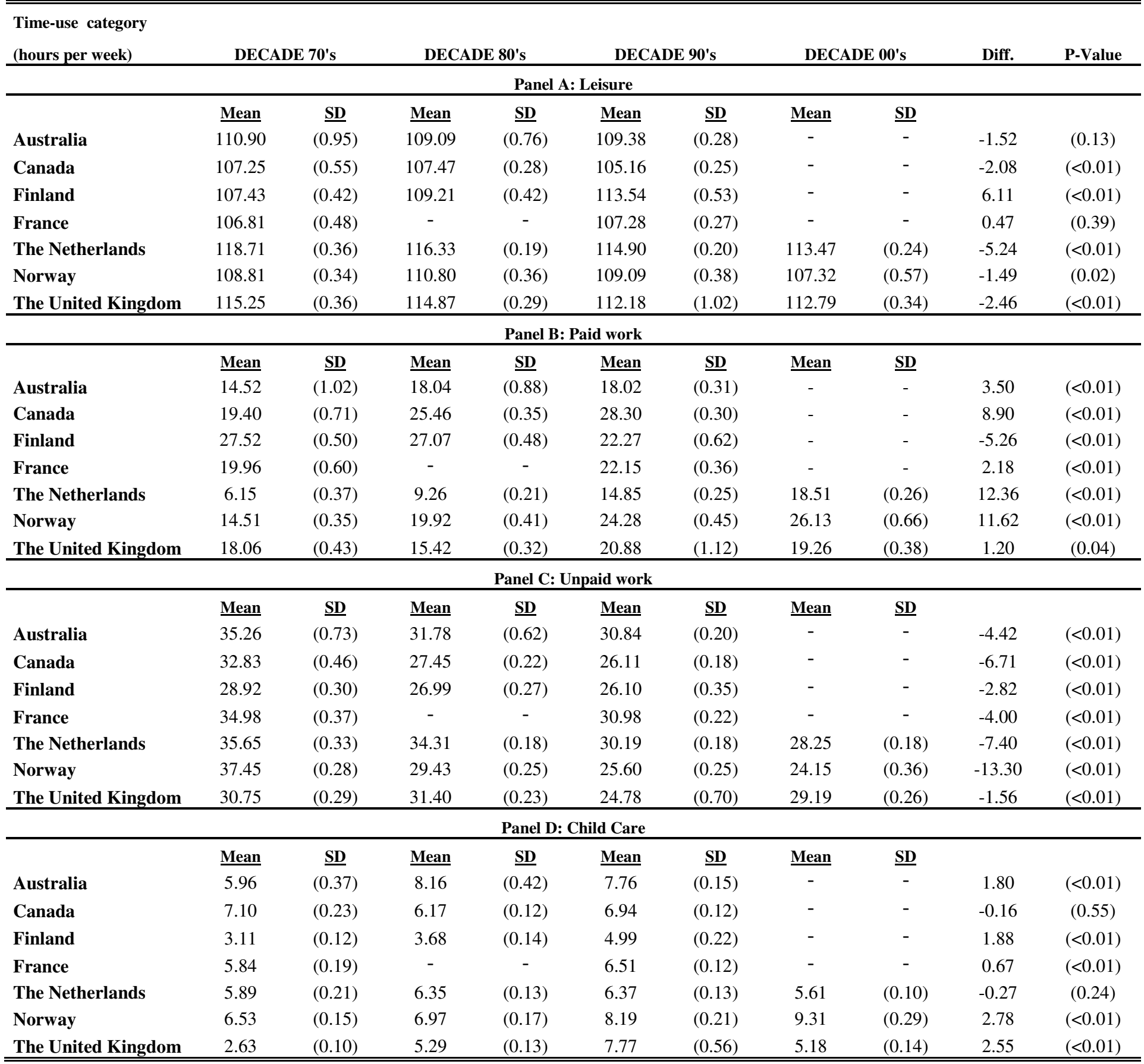

Standard deviations in parenthesis. The sample is restricted to include non-retired/non-student individuals between the ages of 21 and 65 (inclusive), see Appendix Table A1 for a description of the surveys included. Leisure, paid work, unpaid work and child care are measured in hours per week, see Table Appendix A2 for definitions of time use variables. Demographic weighting proposed by Katz and Murphy (1992) and used by Aguiar and Hurst (2007) are used to ensure a constant representation of types of individuals and days of the week. $\mathrm{T}_{\mathrm{i}}$ is Decade 2000's for the Netherlands, Norway and the United Kingdom, and Decade 1990's for Australia, Canada, Finland and France. 
Table 4. Trends in total work (men and women)

\begin{tabular}{|c|c|c|c|c|c|c|c|c|c|c|c|c|c|}
\hline \multirow[t]{2}{*}{$\begin{array}{l}\text { Total Work } \\
\text { (hours per week) }\end{array}$} & & \multicolumn{3}{|c|}{ DECADE 70's } & \multicolumn{3}{|c|}{ DECADE 80's } & \multicolumn{3}{|c|}{ DECADE 90's } & \multicolumn{3}{|c|}{ DECADE 00's } \\
\hline & & Mean & SD & $\underline{\text { Diff }}$ & Mean & $\underline{\text { SD }}$ & $\underline{\text { Diff }}$ & Mean & $\underline{\text { SD }}$ & $\underline{\text { Diff }}$ & Mean & & $\underline{\text { Diff }}$ \\
\hline \multirow[t]{2}{*}{ Australia } & Men & $\overline{64.14}$ & $(\overline{1.22})$ & $\overline{8.40}$ & $\overline{63.68}$ & $(\overline{0.85})$ & $\overline{5.70}$ & $\overline{59.78}$ & $(\overline{0.33})$ & $\overline{3.16}$ & - & - & - \\
\hline & Women & 55.74 & (1.03) & $(<0.01)$ & 57.98 & $(0.81)$ & $(<0.01)$ & 56.62 & $(0.29)$ & $(<0.01)$ & - & - & - \\
\hline \multirow[t]{2}{*}{ Canada } & Men & 61.33 & $(0.78)$ & 2.00 & 60.34 & $(0.37)$ & 1.27 & 61.16 & $(0.32)$ & -0.19 & - & - & - \\
\hline & Women & 59.33 & $(0.56)$ & $(0.04)$ & 59.07 & $(0.29)$ & $(0.01)$ & 61.35 & $(0.25)$ & $(0.64)$ & - & - & - \\
\hline \multirow[t]{2}{*}{ Finland } & Men & 54.97 & $(0.52)$ & -4.58 & 55.81 & $(0.52)$ & -1.92 & 48.85 & $(0.71)$ & -4.51 & - & - & - \\
\hline & Women & 59.55 & $(0.41)$ & $(<0.01)$ & 57.73 & $(0.40)$ & $(<0.01)$ & 53.36 & $(0.52)$ & $(<0.01)$ & - & - & - \\
\hline \multirow[t]{2}{*}{ France } & Men & 53.37 & $(0.65)$ & -7.41 & - & & - & 56.47 & $(0.38)$ & -3.17 & - & - & - \\
\hline & Women & 60.78 & $(0.48)$ & $(<0.01)$ & - & & - & 59.64 & $(0.28)$ & $(<0.01)$ & - & - & - \\
\hline \multirow[t]{2}{*}{ The Netherlands } & Men & 51.82 & $(0.70)$ & 4.13 & 53.39 & $(0.29)$ & 3.46 & 57.89 & $(0.26)$ & 6.48 & 59.40 & $(0.34)$ & 7.03 \\
\hline & Women & 47.69 & $(0.37)$ & $(<0.01)$ & 49.93 & $(0.20)$ & $(<0.01)$ & 51.41 & $(0.21)$ & $(<0.01)$ & 52.37 & $(0.25)$ & $(<0.01)$ \\
\hline \multirow[t]{2}{*}{ Norway } & Men & 58.60 & $(0.43)$ & 0.12 & 57.09 & $(0.46)$ & 0.76 & 59.31 & $(0.47)$ & 1.24 & 60.85 & $(0.64)$ & 1.26 \\
\hline & Women & 58.48 & $(0.35)$ & $(0.83)$ & 56.33 & $(0.38)$ & $(0.20)$ & 58.07 & $(0.39)$ & $(0.04)$ & 59.59 & $(0.59)$ & $(0.15)$ \\
\hline \multirow[t]{2}{*}{ The United Kingdom } & Men & 55.47 & $(0.41)$ & 4.03 & 53.66 & $(0.43)$ & 1.54 & 50.63 & $(1.31)$ & -2.80 & 52.31 & $(0.44)$ & -1.32 \\
\hline & Women & 51.44 & $(0.37)$ & $(<0.01)$ & 52.12 & $(0.31)$ & $(<0.01)$ & 53.43 & (1.07) & $(0.10)$ & 53.63 & $(0.36)$ & $(0.02)$ \\
\hline
\end{tabular}

The sample is restricted to include non-retired/non-student individuals between the ages of 21 and 65 (inclusive), see Appendix Table A1 for a description of the surveys included. Total Work is measured in hours per week as is defined as the sum of the time devote to paid work, unpaid work and child care, see Table Appendix A2 for definitions of time use variables The difference in computed as the time devoted to total work by men minus the time devoted to total work by women, P-value of the difference in parenthesis. 
Table 5. Change in the time devoted to leisure activities (men and women)

\begin{tabular}{|c|c|c|c|c|c|c|c|c|c|c|}
\hline Leisure (hours per week) & Total Leisure & $\begin{array}{c}\text { TV } \\
\text { Watching }\end{array}$ & Reading & Eating & Socializing & Sports & Sleeping & $\begin{array}{c}\text { Personal } \\
\text { Care }\end{array}$ & Gardening & $\begin{array}{c}\text { Other } \\
\text { Activities }\end{array}$ \\
\hline \multicolumn{11}{|c|}{ Panel A: Men } \\
\hline Australia & $\begin{array}{c}3.15 \\
(0.02)\end{array}$ & $\begin{array}{c}1.19 \\
(0.04)\end{array}$ & $\begin{array}{c}-0.83 \\
(0.00)\end{array}$ & $\begin{array}{l}-1.61 \\
(0.00)\end{array}$ & $\begin{array}{c}1.07 \\
(0.08)\end{array}$ & $\begin{array}{c}1.83 \\
(0.00)\end{array}$ & $\begin{array}{c}1.45 \\
(0.01)\end{array}$ & $\begin{array}{c}0.69 \\
(0.00)\end{array}$ & $\begin{array}{c}0.43 \\
(0.08)\end{array}$ & $\begin{array}{c}-1.08 \\
(0.07)\end{array}$ \\
\hline Canada & $\begin{array}{c}0.23 \\
(0.78)\end{array}$ & $\begin{array}{c}1.81 \\
(0.00)\end{array}$ & $\begin{array}{l}-1.02 \\
(0.00)\end{array}$ & $\begin{array}{l}-2.58 \\
(0.00)\end{array}$ & $\begin{array}{c}2.35 \\
(0.00)\end{array}$ & $\begin{array}{c}2.29 \\
(0.00)\end{array}$ & $\begin{array}{c}0.69 \\
(0.07)\end{array}$ & $\begin{array}{l}-2.95 \\
(0.00)\end{array}$ & $\begin{array}{c}1.05 \\
(0.00)\end{array}$ & $\begin{array}{l}-1.42 \\
(0.00)\end{array}$ \\
\hline Finland & $\begin{array}{c}6.19 \\
(<0.01)\end{array}$ & $\begin{array}{c}7.00 \\
(0.00)\end{array}$ & $\begin{array}{l}-1.50 \\
(0.00)\end{array}$ & $\begin{array}{l}-3.24 \\
(0.00)\end{array}$ & $\begin{array}{c}1.14 \\
(0.00)\end{array}$ & $\begin{array}{c}0.85 \\
(0.00)\end{array}$ & $\begin{array}{c}1.78 \\
(0.00)\end{array}$ & $\begin{array}{l}-0.24 \\
(0.04)\end{array}$ & $\begin{array}{c}1.27 \\
(0.00)\end{array}$ & $\begin{array}{l}-0.88 \\
(0.01)\end{array}$ \\
\hline France & $\begin{array}{l}-3.97 \\
(<0.01)\end{array}$ & $\begin{array}{c}3.90 \\
(0.00)\end{array}$ & $\begin{array}{l}-1.41 \\
(0.00)\end{array}$ & $\begin{array}{c}0.29 \\
(0.08)\end{array}$ & $\begin{array}{l}-2.80 \\
(0.00)\end{array}$ & $\begin{array}{c}0.92 \\
(0.00)\end{array}$ & $\begin{array}{c}1.31 \\
(0.00)\end{array}$ & $\begin{array}{l}-3.98 \\
(0.00)\end{array}$ & $\begin{array}{c}0.04 \\
(0.73)\end{array}$ & $\begin{array}{l}-2.22 \\
(0.00)\end{array}$ \\
\hline The Netherlands & $\begin{array}{l}-7.68 \\
(<0.01)\end{array}$ & $\begin{array}{l}-1.16 \\
(0.00)\end{array}$ & $\begin{array}{l}-2.56 \\
(0.00)\end{array}$ & $\begin{array}{l}-0.93 \\
(0.00)\end{array}$ & $\begin{array}{l}-2.81 \\
(0.00)\end{array}$ & $\begin{array}{c}0.24 \\
(0.13)\end{array}$ & $\begin{array}{c}0.01 \\
(0.99)\end{array}$ & $\begin{array}{l}-0.61 \\
(0.24)\end{array}$ & $\begin{array}{l}-0.38 \\
(0.00)\end{array}$ & $\begin{array}{c}0.53 \\
(0.08)\end{array}$ \\
\hline Norway & $\begin{array}{l}-2.89 \\
(<0.01)\end{array}$ & $\begin{array}{c}4.95 \\
(0.00)\end{array}$ & $\begin{array}{l}-0.73 \\
(0.00)\end{array}$ & $\begin{array}{l}-2.09 \\
(0.00)\end{array}$ & $\begin{array}{l}-0.82 \\
(0.04)\end{array}$ & $\begin{array}{c}0.44 \\
(0.02)\end{array}$ & $\begin{array}{l}-1.95 \\
(0.00)\end{array}$ & $\begin{array}{l}-2.43 \\
(0.00)\end{array}$ & $\begin{array}{l}-0.58 \\
(0.00)\end{array}$ & $\begin{array}{c}0.32 \\
(0.29)\end{array}$ \\
\hline The United Kingdom & $\begin{array}{c}2.95 \\
(<0.01) \\
\end{array}$ & $\begin{array}{r}1.50 \\
(0.00) \\
\end{array}$ & $\begin{array}{l}-0.15 \\
(0.16) \\
\end{array}$ & $\begin{array}{l}-1.96 \\
(0.00) \\
\end{array}$ & $\begin{array}{c}1.43 \\
(0.00) \\
\end{array}$ & $\begin{array}{c}1.89 \\
(0.00) \\
\end{array}$ & $\begin{array}{c}2.83 \\
(0.00) \\
\end{array}$ & $\begin{array}{l}-1.15 \\
(0.00) \\
\end{array}$ & $\begin{array}{c}0.51 \\
(0.00) \\
\end{array}$ & $\begin{array}{l}-1.95 \\
(0.00) \\
\end{array}$ \\
\hline \multicolumn{11}{|c|}{ Panel B: Women } \\
\hline Australia & $\begin{array}{l}-1.52 \\
(0.13)\end{array}$ & $\begin{array}{l}-0.87 \\
(0.07)\end{array}$ & $\begin{array}{l}-0.52 \\
(0.01)\end{array}$ & $\begin{array}{l}-3.00 \\
(0.00)\end{array}$ & $\begin{array}{c}1.88 \\
(0.00)\end{array}$ & $\begin{array}{c}1.34 \\
(0.00)\end{array}$ & $\begin{array}{l}-1.34 \\
(0.01)\end{array}$ & $\begin{array}{c}1.03 \\
(0.00)\end{array}$ & $\begin{array}{c}0.62 \\
(0.00)\end{array}$ & $\begin{array}{l}-0.66 \\
(0.21)\end{array}$ \\
\hline Canada & $\begin{array}{l}-2.08 \\
(<0.01)\end{array}$ & $\begin{array}{c}1.36 \\
(0.00)\end{array}$ & $\begin{array}{l}-0.15 \\
(0.26)\end{array}$ & $\begin{array}{l}-3.43 \\
(0.00)\end{array}$ & $\begin{array}{c}2.50 \\
(0.00)\end{array}$ & $\begin{array}{c}1.54 \\
(0.00)\end{array}$ & $\begin{array}{c}0.34 \\
(0.30)\end{array}$ & $\begin{array}{l}-2.10 \\
(0.00)\end{array}$ & $\begin{array}{c}0.42 \\
(0.00)\end{array}$ & $\begin{array}{l}-2.57 \\
(0.00)\end{array}$ \\
\hline Finland & $\begin{array}{c}6.11 \\
(<0.01)\end{array}$ & $\begin{array}{c}5.05 \\
(0.00)\end{array}$ & $\begin{array}{l}-0.24 \\
(0.12)\end{array}$ & $\begin{array}{l}-2.05 \\
(0.00)\end{array}$ & $\begin{array}{c}0.48 \\
(0.08)\end{array}$ & $\begin{array}{c}1.76 \\
(0.00)\end{array}$ & $\begin{array}{c}1.95 \\
(0.00)\end{array}$ & $\begin{array}{c}0.29 \\
(0.01)\end{array}$ & $\begin{array}{c}1.62 \\
(0.00)\end{array}$ & $\begin{array}{l}-2.76 \\
(0.00)\end{array}$ \\
\hline France & $\begin{array}{c}0.47 \\
(0.39)\end{array}$ & $\begin{array}{c}3.13 \\
(0.00)\end{array}$ & $\begin{array}{l}-0.44 \\
(0.00)\end{array}$ & $\begin{array}{c}0.95 \\
(0.00)\end{array}$ & $\begin{array}{l}-1.80 \\
(0.00)\end{array}$ & $\begin{array}{c}1.38 \\
(0.00)\end{array}$ & $\begin{array}{c}3.39 \\
(0.00)\end{array}$ & $\begin{array}{l}-4.10 \\
(0.00)\end{array}$ & $\begin{array}{c}0.08 \\
(0.27)\end{array}$ & $\begin{array}{l}-2.10 \\
(0.00)\end{array}$ \\
\hline The Netherlands & $\begin{array}{l}-5.24 \\
(<0.01)\end{array}$ & $\begin{array}{l}-0.12 \\
(0.59)\end{array}$ & $\begin{array}{l}-2.11 \\
(0.00)\end{array}$ & $\begin{array}{l}-1.48 \\
(0.00)\end{array}$ & $\begin{array}{l}-3.26 \\
(0.00)\end{array}$ & $\begin{array}{c}1.02 \\
(0.00)\end{array}$ & $\begin{array}{c}0.93 \\
(0.00)\end{array}$ & $\begin{array}{c}0.36 \\
(0.13)\end{array}$ & $\begin{array}{c}0.09 \\
(0.04)\end{array}$ & $\begin{array}{c}-0.66 \\
(0.00)\end{array}$ \\
\hline Norway & $\begin{array}{l}-1.49 \\
(0.02)\end{array}$ & $\begin{array}{c}4.28 \\
(0.00)\end{array}$ & $\begin{array}{c}0.57 \\
(0.00)\end{array}$ & $\begin{array}{l}-2.35 \\
(0.00)\end{array}$ & $\begin{array}{c}-0.39 \\
(0.31)\end{array}$ & $\begin{array}{c}0.69 \\
(0.00)\end{array}$ & $\begin{array}{c}-1.70 \\
(0.00)\end{array}$ & $\begin{array}{c}-2.39 \\
(0.00)\end{array}$ & $\begin{array}{c}-0.56 \\
(0.00)\end{array}$ & $\begin{array}{c}0.35 \\
(0.17)\end{array}$ \\
\hline The United Kingdom & $\begin{array}{c}-2.46 \\
(<0.01)\end{array}$ & $\begin{array}{c}-0.86 \\
(0.01)\end{array}$ & $\begin{array}{c}0.46 \\
(0.00)\end{array}$ & $\begin{array}{l}-2.63 \\
(0.00)\end{array}$ & $\begin{array}{c}-0.66 \\
(0.03)\end{array}$ & $\begin{array}{c}1.47 \\
(0.00)\end{array}$ & $\begin{array}{c}3.41 \\
(0.00)\end{array}$ & $\begin{array}{l}-1.03 \\
(0.00)\end{array}$ & $\begin{array}{c}0.41 \\
(0.00)\end{array}$ & $\begin{array}{l}-3.03 \\
(0.00)\end{array}$ \\
\hline
\end{tabular}

The sample is restricted to include non-retired/non-student individuals between the ages of 21 and 65 (inclusive), see Appendix Table A1 for a description of the surveys included. Leisure activities are measured in hours per week, see Table Appendix A3 for definitions of leisure activities. Demographic weighting proposed by Katz and Murphy (1992) and used by Aguiar and Hurst (2007) are used to ensure a constant representation of types of individuals and days of the week, p-value of the difference in parentheses. 
Table 6. Number of TV channels, by country and decade

\begin{tabular}{lcc}
\hline \hline Number of TV Channels & DECADE 90's & DECADE 00's \\
\hline Australia & 104 & - \\
Canada & 80 & 150 \\
Finland & 120 & 260 \\
France & 584 & 855 \\
The Netherlands & 21 & 671 \\
Norway & 360 & - \\
The United Kingdom & 228 & 685
\end{tabular}

Sources: The CIA World Factbook (Central intelligence Agency, www.cia.gov) and the Database on TV companies and TV channels in the European Union and candidate countries (MAVISE, http://mavise.obs.coe.int) datasets.

Table 7. Trends in leisure inequality (men and women)

\begin{tabular}{lcccc}
\hline \hline & $\begin{array}{c}\text { DECADE } \\
\text { 1970s }\end{array}$ & $\begin{array}{c}\text { DECADE } \\
\text { 1980s }\end{array}$ & $\begin{array}{c}\text { DECADE } \\
\text { 1990s }\end{array}$ & $\begin{array}{c}\text { DECADE } \\
\text { 2000s }\end{array}$ \\
\hline \multicolumn{4}{c}{ Panel A: Gini Index } \\
\hline Australia & 12.87 & 13.99 & 14.25 & - \\
Canada & 12.97 & 14.26 & 15.47 & - \\
Finland & 13.12 & 13.84 & 13.82 & - \\
France & 13.27 & - & 13.56 & - \\
The Netherlands & 6.650 & 6.940 & 7.470 & 13.800 \\
Norway & 13.26 & 13.32 & 13.83 & 14.54 \\
The United Kingdom & 11.72 & 12.51 & 14.16 & 13.62 \\
\hline \multicolumn{5}{c}{ Panel B: 90th/10th } \\
\hline Australia & 1.783 & 1.879 & 1.924 \\
Canada & 1.815 & 1.938 & 2.081 & - \\
Finland & 1.855 & 1.912 & 1.928 & - \\
France & 1.848 & - & 1.853 & - \\
The Netherlands & 1.313 & 1.338 & 1.380 & 1.911 \\
Norway & 1.867 & 1.848 & 1.867 & 1.969 \\
The United Kingdom & 1.680 & 1.771 & 1.913 & 1.884 \\
\hline \hline
\end{tabular}


Table 8. Trends in income and earnings inequality (men and women)

\begin{tabular}{lcccc}
\hline \hline & $\begin{array}{c}\text { DECADE } \\
\text { 1970s }\end{array}$ & $\begin{array}{c}\text { DECADE } \\
\text { 1980s }\end{array}$ & $\begin{array}{c}\text { DECADE } \\
\text { 1990s }\end{array}$ & $\begin{array}{c}\text { DECADE } \\
\text { 2000s }\end{array}$ \\
\hline & \multicolumn{4}{c}{ Panel A: Gini Index } \\
\hline Australia & 30.896 & 33.261 & 37.459 & - \\
Canada & 34.459 & 36.008 & 37.379 & - \\
Finland & 31.119 & 30.960 & 33.61 & - \\
$\begin{array}{l}\text { France } \\
\text { The Netherlands }\end{array}$ & 33.356 & 33.855 & 34.91 & - \\
Norway & 32.816 & 33.525 & 35.461 & - \\
The United & 31.209 & 32.362 & 34.226 & - \\
Kingdom & & & & \\
\hline & 29.851 & 33.328 & 35.292 & - \\
\hline $\begin{array}{l}\text { Australia } \\
\text { Canada }\end{array}$ & 2.641 & 2.858 & 2.878 & 3.084 \\
Finland & 3.733 & 4.311 & 3.973 & 3.662 \\
France & 2.649 & 2.495 & 2.372 & 2.43 \\
The Netherlands & 3.493 & 3.185 & 3.147 & 2.971 \\
Norway & 2.573 & 2.510 & 2.710 & 2.906 \\
The United & - & - & 1.962 & 2.061 \\
Kingdom & 3.176 & 3.198 & 3.426 & 3.517 \\
\hline \hline
\end{tabular}

Index for income obtained from the World Bank Dataset (data.worldbank.org). Data are based on primary household survey data obtained from government statistical agencies and World Bank country departments. Data for high-income economies are from the Luxembourg Income Study database. We calculate the 90 to 10 earnings percentile ratio using the 90 and 10 earnings percentiles from the OECD Earnings database (stats.oecd.org). The ninth and first deciles are upper-earnings decile limits, unless otherwise indicated, of gross earnings of full-time dependent employees. 
Table 9. Leisure inequality, low and highly educated (men and women)

\begin{tabular}{|c|c|c|c|c|c|c|c|c|c|c|c|}
\hline \multirow[t]{2}{*}{$\begin{array}{l}\text { Time-use category } \\
\text { (hours per week) }\end{array}$} & & \multicolumn{2}{|c|}{ DECADE 70's } & \multicolumn{2}{|c|}{ DECADE 80's } & \multicolumn{2}{|c|}{ DECADE 90's } & \multicolumn{2}{|c|}{ DECADE 00's } & \multirow[t]{2}{*}{ Diff. } & \multirow[t]{2}{*}{$\begin{array}{c}\text { Cum. } \\
\text { Diff }\end{array}$} \\
\hline & \multirow{2}{*}{\multicolumn{10}{|c|}{ Panel A: Men }} & \\
\hline \multirow{3}{*}{ Australia } & & Mean & $\underline{\text { SD }}$ & Mean & & & & & & & \\
\hline & Less than high-school & 104.67 & $(2.42)$ & 106.44 & $(1.67)$ & 110.62 & $(0.67)$ & - & - & 5.95 & 3.86 \\
\hline & Some college and college grads & 101.89 & $(4.02)$ & 101.14 & $(1.12)$ & 103.98 & $(0.63)$ & - & - & 2.09 & $(0.42)$ \\
\hline \multirow[t]{2}{*}{ Canada } & Less than high-school & 104.56 & $(0.96)$ & 110.57 & $(0.64)$ & 111.68 & $(0.70)$ & - & - & 7.12 & 8.79 \\
\hline & Some college and college grads & 105.86 & $(1.35)$ & 104.15 & $(0.52)$ & 104.19 & $(0.40)$ & - & - & -1.67 & $(<0.01)$ \\
\hline \multirow[t]{2}{*}{ Finland } & Less than high-school & 111.61 & $(0.54)$ & 111.10 & $(0.59)$ & 118.11 & $(0.74)$ & - & - & 6.50 & 0.19 \\
\hline & Some college and college grads & 108.75 & $(1.46)$ & 107.69 & $(1.17)$ & 115.06 & $(1.39)$ & - & - & 6.31 & $(0.94)$ \\
\hline \multirow[t]{2}{*}{ France } & Less than high-school & 114.96 & $(0.92)$ & - & - & 115.17 & $(1.07)$ & - & - & 0.21 & 3.72 \\
\hline & Some college and college grads & 111.19 & $(1.48)$ & - & - & 107.68 & $(0.56)$ & - & - & -3.51 & $(0.08)$ \\
\hline \multirow[t]{2}{*}{ The Netherlands } & Less than high-school & 115.25 & $(0.90)$ & 114.81 & $(0.42)$ & 112.33 & $(0.50)$ & 112.59 & $(0.79)$ & -2.66 & 4.88 \\
\hline & Some college and college grads & 112.24 & $(1.64)$ & 108.88 & $(0.54)$ & 106.72 & $(0.42)$ & 104.70 & $(0.51)$ & -7.54 & $(0.02)$ \\
\hline \multirow[t]{2}{*}{ Norway } & Less than high-school & - & - & 111.18 & $(0.64)$ & 109.56 & $(1.45)$ & 105.00 & $(2.24)$ & -6.18 & -1.88 \\
\hline & Some college and college grads & - & - & 108.22 & $(1.06)$ & 108.15 & $(0.96)$ & 103.92 & $(1.08)$ & -4.30 & $(0.50)$ \\
\hline \multirow[t]{2}{*}{ The United Kingdom } & Less than high-school & 111.79 & $(0.52)$ & 114.94 & $(0.63)$ & 126.06 & $(6.25)$ & 115.87 & $(0.77)$ & 4.08 & 3.61 \\
\hline & Some college and college grads & 112.39 & $(1.26)$ & 110.12 & $(0.88)$ & 110.32 & $(2.62)$ & 112.86 & $(0.81)$ & 0.47 & $(0.04)$ \\
\hline \multicolumn{12}{|c|}{ Panel B: Women } \\
\hline \multirow{3}{*}{ Australia } & & $\underline{\text { Mean }}$ & $\underline{\text { SD }}$ & $\underline{\text { Mean }}$ & $\underline{\text { SD }}$ & $\underline{\text { Mean }}$ & $\underline{\text { SD }}$ & $\underline{\text { Mean }}$ & $\underline{\text { SD }}$ & & \\
\hline & Less than high-school & 111.69 & $(1.45)$ & 112.64 & $(1.08)$ & 112.42 & $(0.40)$ & - & - & 0.73 & 3.22 \\
\hline & Some college and college grads & 106.30 & $(2.36)$ & 104.21 & $(1.05)$ & 103.81 & $(0.54)$ & - & - & -2.49 & $(0.26)$ \\
\hline \multirow[t]{2}{*}{ Canada } & Less than high-school & 108.53 & $(0.68)$ & 112.59 & $(0.48)$ & 113.18 & $(0.55)$ & - & - & 4.65 & 7.76 \\
\hline & Some college and college grads & 106.09 & $(1.16)$ & 104.54 & $(0.43)$ & 102.98 & $(0.32)$ & - & - & -3.11 & $(<0.01)$ \\
\hline \multirow[t]{2}{*}{ Finland } & Less than high-school & 107.88 & $(0.47)$ & 109.23 & $(0.55)$ & 113.61 & $(0.63)$ & - & - & 5.73 & -2.10 \\
\hline & Some college and college grads & 105.56 & $(0.98)$ & 106.44 & $(1.03)$ & 113.39 & $(1.27)$ & - & - & 7.83 & $(0.24)$ \\
\hline \multirow[t]{2}{*}{ France } & Less than high-school & 107.53 & $(0.63)$ & - & - & 111.32 & $(0.67)$ & - & - & 3.79 & 6.54 \\
\hline & Some college and college grads & 106.90 & $(1.61)$ & - & - & 104.15 & $(0.41)$ & - & - & -2.75 & $(<0.01)$ \\
\hline \multirow[t]{2}{*}{ The Netherlands } & Less than high-school & 119.32 & $(0.40)$ & 117.16 & $(0.21)$ & 117.59 & $(0.30)$ & 117.32 & $(0.48)$ & -2.00 & 3.70 \\
\hline & Some college and college grads & 115.47 & $(1.02)$ & 112.34 & $(0.64)$ & 111.75 & $(0.43)$ & 109.77 & $(0.43)$ & -5.70 & $(<0.01)$ \\
\hline \multirow[t]{2}{*}{ Norway } & Less than high-school & - & - & 111.75 & $(0.48)$ & 111.83 & $(1.00)$ & 115.18 & $(2.03)$ & 3.43 & 5.54 \\
\hline & Some college and college grads & - & - & 107.64 & $(1.03)$ & 104.92 & $(0.75)$ & 105.53 & $(0.99)$ & -2.11 & $(0.10)$ \\
\hline \multirow[t]{2}{*}{ The United Kingdom } & Less than high-school & 115.97 & $(0.43)$ & 116.03 & $(0.37)$ & 119.38 & $(5.13)$ & 114.34 & $(0.55)$ & -1.63 & 1.30 \\
\hline & Some college and college grads & 114.28 & $(1.17)$ & 109.63 & $(0.65)$ & 106.74 & $(2.40)$ & 111.35 & $(0.64)$ & -2.93 & $(0.39)$ \\
\hline
\end{tabular}

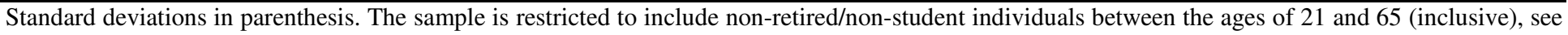

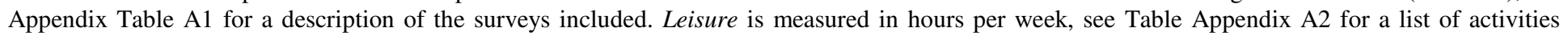

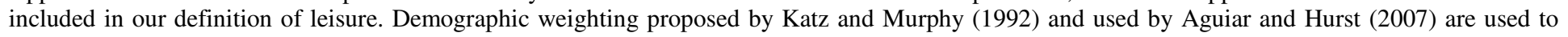

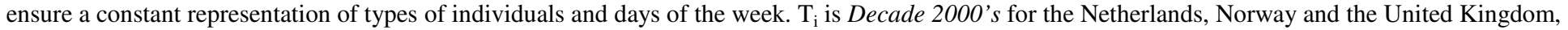

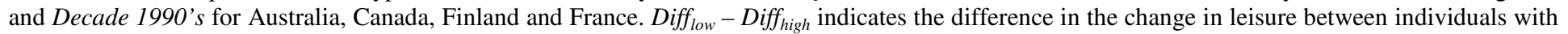

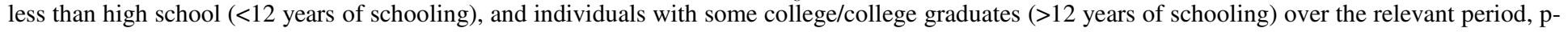
value of such difference in parentheses. 
Table 10. Correlations between total household income and individual leisure time

\begin{tabular}{lcccc}
\hline \hline & $\begin{array}{c}\text { DECADE } \\
\text { 1970's }\end{array}$ & $\begin{array}{c}\text { DECADE } \\
\text { 1980'S }\end{array}$ & $\begin{array}{c}\text { DECADE } \\
\text { 1990'S }\end{array}$ & $\begin{array}{c}\text { DECADE } \\
\text { 2000'S }\end{array}$ \\
\hline Australia & -0.15 & -0.40 & -0.16 & - \\
Canada & -0.09 & -0.22 & -0.26 & - \\
Finland & Not available & -0.12 & -0.20 & - \\
France & Not available & - & -0.24 & - \\
The Netherlands & Not available & -0.24 & -0.26 & 0.10 \\
Norway & -0.06 & -0.13 & -0.19 & -0.18 \\
The United Kingdom & Not available & -0.20 & -0.28 & -0.22
\end{tabular}

The sample is restricted to include non-retired/non-student individuals between the ages of 21 and 65 (inclusive), see Appendix Table A1 for a description of the surveys included. 
Table 11. Inequality in paid work over the period, low and highly-educated (men and women)

\begin{tabular}{|c|c|c|c|c|c|c|c|c|c|c|c|}
\hline \multirow[t]{2}{*}{$\begin{array}{l}\text { Time-use category } \\
\text { (hours per week) }\end{array}$} & & \multicolumn{2}{|c|}{ DECADE 70's } & \multicolumn{2}{|c|}{ DECADE 80's } & \multicolumn{2}{|c|}{ DECADE 90's } & \multicolumn{2}{|c|}{ DECADE 00's } & \multirow[t]{2}{*}{ Diff. } & \multirow[t]{2}{*}{$\begin{array}{c}\text { Cum. } \\
\text { Diff }\end{array}$} \\
\hline \multirow{2}{*}{\multicolumn{12}{|c|}{ Panel A: Men }} \\
\hline & & & & & & & & & & & \\
\hline \multirow[t]{2}{*}{ Australia } & Less than high-school & $\overline{52.43}$ & $(\overline{2.94})$ & $\overline{47.43}$ & $(\overline{2.06})$ & $\overline{40.15}$ & $(\overline{0.80})$ & $\overline{-}$ & - & -12.29 & -4.23 \\
\hline & Some college and college grads & 52.83 & $(5.25)$ & 52.40 & $(1.34)$ & 44.77 & $(0.77)$ & - & - & -8.06 & $(0.49)$ \\
\hline \multirow[t]{2}{*}{ Canada } & Less than high-school & 48.34 & $(1.17)$ & 39.92 & $(0.74)$ & 38.22 & $(0.80)$ & - & - & -10.12 & -8.22 \\
\hline & Some college and college grads & 47.25 & $(1.49)$ & 46.93 & $(0.61)$ & 45.34 & $(0.46)$ & - & - & -1.90 & $(<0.01)$ \\
\hline \multirow[t]{2}{*}{ Finland } & Less than high-school & 39.17 & $(0.60)$ & 39.05 & $(0.66)$ & 30.73 & $(0.82)$ & - & - & -8.44 & 2.33 \\
\hline & Some college and college grads & 43.16 & $(1.63)$ & 38.90 & $(1.36)$ & 32.39 & $(1.60)$ & - & - & -10.77 & $(0.35)$ \\
\hline \multirow[t]{2}{*}{ France } & Less than high-school & 40.16 & $(1.04)$ & - & - & 37.68 & $(1.25)$ & - & - & -2.48 & -4.18 \\
\hline & Some college and college grads & 42.23 & $(1.73)$ & - & - & 43.93 & $(0.69)$ & - & - & 1.70 & $(0.09)$ \\
\hline \multirow[t]{2}{*}{ The Netherlands } & Less than high-school & 38.65 & $(1.02)$ & 36.21 & $(0.51)$ & 37.02 & $(0.63)$ & 36.93 & $(0.91)$ & -1.72 & -6.32 \\
\hline & Some college and college grads & 40.26 & $(1.98)$ & 41.70 & $(0.67)$ & 44.27 & $(0.49)$ & 44.87 & $(0.62)$ & 4.60 & $(0.01)$ \\
\hline \multirow{2}{*}{ Norway } & Less than high-school & - & - & 41.81 & $(0.72)$ & 39.26 & $(1.54)$ & 41.84 & $(2.71)$ & 0.03 & -0.73 \\
\hline & Some college and college grads & - & - & 39.53 & $(1.20)$ & 41.88 & $(1.06)$ & 40.30 & $(1.35)$ & 0.76 & $(0.83)$ \\
\hline \multirow[t]{2}{*}{ The United Kingdom } & Less than high-school & 47.24 & $(0.61)$ & 36.84 & $(0.75)$ & 30.17 & $(6.39)$ & 31.94 & $(0.90)$ & -15.30 & -6.19 \\
\hline & Some college and college grads & 44.22 & $(1.46)$ & 39.11 & $(1.08)$ & 41.33 & $(2.99)$ & 35.11 & $(0.97)$ & -9.11 & $(<0.01)$ \\
\hline \multicolumn{12}{|c|}{ Panel B: Women } \\
\hline \multirow{3}{*}{ Australia } & & Mean & $\underline{\text { SD }}$ & Mean & $\underline{\text { SD }}$ & Mean & $\underline{\text { SD }}$ & Mean & $\underline{\mathrm{SD}}$ & & \\
\hline & Less than high-school & 14.21 & $(1.52)$ & 13.88 & $(1.17)$ & 14.11 & $(0.43)$ & - & - & -0.10 & -11.87 \\
\hline & Some college and college grads & 13.50 & $(2.60)$ & 23.65 & $(1.39)$ & 25.27 & $(0.67)$ & - & - & 11.77 & $(<0.01)$ \\
\hline \multirow[t]{2}{*}{ Canada } & Less than high-school & 14.61 & $(0.81)$ & 16.05 & $(0.52)$ & 17.42 & $(0.57)$ & - & - & 2.81 & -2.41 \\
\hline & Some college and college grads & 26.65 & $(1.60)$ & 31.56 & $(0.55)$ & 31.87 & $(0.40)$ & - & - & 5.22 & $(0.21)$ \\
\hline \multirow[t]{2}{*}{ Finland } & Less than high-school & 26.71 & $(0.56)$ & 26.61 & $(0.64)$ & 22.17 & $(0.73)$ & - & - & -4.54 & 5.86 \\
\hline & Some college and college grads & 35.29 & $(1.17)$ & 31.03 & $(1.27)$ & 24.89 & $(1.44)$ & - & - & -10.40 & $(<0.01)$ \\
\hline \multirow[t]{2}{*}{ France } & Less than high-school & 16.72 & $(0.77)$ & - & - & 11.97 & $(0.76)$ & - & - & -4.76 & -9.24 \\
\hline & Some college and college grads & 25.94 & $(1.95)$ & - & - & 30.42 & $(0.57)$ & - & - & 4.48 & $(<0.01)$ \\
\hline \multirow[t]{2}{*}{ The Netherlands } & Less than high-school & 5.19 & $(0.37)$ & 6.88 & $(0.20)$ & 8.78 & $(0.28)$ & 10.22 & $(0.41)$ & 5.03 & -13.15 \\
\hline & Some college and college grads & 9.11 & $(1.51)$ & 20.28 & $(0.90)$ & 25.53 & $(0.60)$ & 27.29 & $(0.53)$ & 18.18 & $(<0.01)$ \\
\hline \multirow[t]{2}{*}{ Norway } & Less than high-school & - & - & 18.81 & $(0.55)$ & 22.41 & $(1.14)$ & 21.65 & $(2.21)$ & 2.84 & 1.19 \\
\hline & Some college and college grads & - & - & 23.62 & $(1.15)$ & 28.92 & $(0.99)$ & 25.27 & $(1.17)$ & 1.65 & $(0.21)$ \\
\hline \multirow[t]{2}{*}{ The United Kingdom } & Less than high-school & 17.31 & $(0.52)$ & 13.02 & $(0.39)$ & 16.44 & $(5.18)$ & 16.10 & $(0.59)$ & -1.21 & -5.13 \\
\hline & Some college and college grads & 20.82 & $(1.38)$ & 23.65 & $(0.85)$ & 33.02 & $(2.93)$ & 24.74 & $(0.74)$ & 3.92 & $(<0.01)$ \\
\hline
\end{tabular}

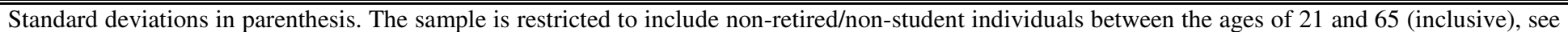

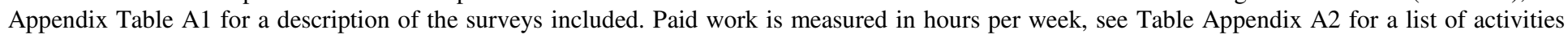

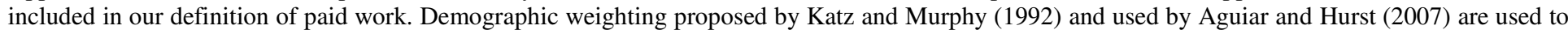

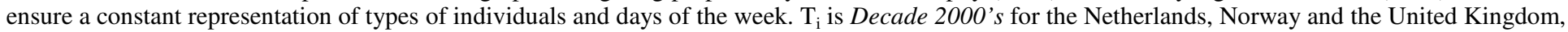

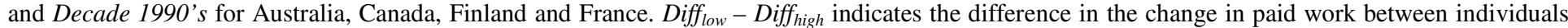

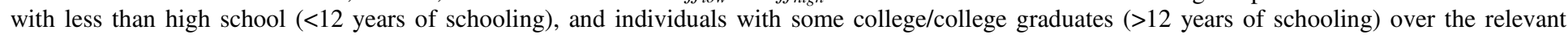
period, $\mathrm{p}$-value of such difference in parentheses. 
Table 12. Inequality in unpaid work over the period, low and highly-educated (men and women)

\begin{tabular}{|c|c|c|c|c|c|c|c|c|c|c|c|}
\hline \multirow[t]{3}{*}{$\begin{array}{l}\text { Time-use category } \\
\text { (hours per week) }\end{array}$} & & \multicolumn{2}{|c|}{ DECADE 70's } & \multicolumn{2}{|c|}{ DECADE 80's } & \multicolumn{2}{|c|}{ DECADE 90's } & \multicolumn{2}{|c|}{ DECADE 00's } & \multirow[t]{2}{*}{ Diff. } & \multirow[t]{2}{*}{$\begin{array}{c}\text { Cum. } \\
\text { Diff }\end{array}$} \\
\hline & & \multicolumn{4}{|c|}{ Panel A: Men } & \multirow[b]{2}{*}{$\underline{\text { Mean }}$} & \multirow{4}{*}{$\begin{array}{c}\underline{\text { SD }} \\
(0.35) \\
(0.35)\end{array}$} & \multirow[b]{2}{*}{$\underline{\text { Mean }}$} & \multirow[b]{2}{*}{$\underline{\text { SD }}$} & & \\
\hline & & $\underline{\text { Mean }}$ & $\underline{\text { SD }}$ & $\underline{\text { Mean }}$ & $\underline{\text { SD }}$ & & & & & & \\
\hline Australia & Less than high-school & 10.04 & $(1.20)$ & 11.88 & $(0.89)$ & 13.77 & & - & - & 3.73 & -0.45 \\
\hline & Some college and college grads & 10.12 & $(1.82)$ & 11.17 & $(0.53)$ & 14.30 & & - & - & 4.18 & $(0.84)$ \\
\hline \multirow[t]{2}{*}{ Canada } & Less than high-school & 12.63 & $(0.55)$ & 14.82 & $(0.42)$ & 14.98 & $(0.40)$ & - & - & 2.35 & -0.20 \\
\hline & Some college and college grads & 11.64 & $(0.60)$ & 13.44 & $(0.29)$ & 14.19 & $(0.21)$ & - & - & 2.55 & $(0.83)$ \\
\hline \multirow[t]{2}{*}{ Finland } & Less than high-school & 14.83 & $(0.30)$ & 15.75 & $(0.30)$ & 16.01 & $(0.40)$ & - & - & 1.19 & -2.69 \\
\hline & Some college and college grads & 11.88 & $(0.69)$ & 16.48 & $(0.67)$ & 15.76 & $(0.70)$ & - & - & 3.88 & $(0.01)$ \\
\hline \multirow[t]{2}{*}{ France } & Less than high-school & 11.33 & $(0.38)$ & - & - & 12.30 & $(0.51)$ & - & - & 0.97 & -0.31 \\
\hline & Some college and college grads & 11.22 & $(0.67)$ & - & - & 12.50 & $(0.29)$ & - & - & 1.28 & $(0.74)$ \\
\hline \multirow[t]{2}{*}{ The Netherlands } & Less than high-school & 10.06 & $(0.45)$ & 13.32 & $(0.26)$ & 14.87 & $(0.35)$ & 15.07 & $(0.40)$ & 5.01 & 2.24 \\
\hline & Some college and college grads & 10.29 & $(1.21)$ & 12.28 & $(0.37)$ & 12.24 & $(0.27)$ & 13.06 & $(0.27)$ & 2.77 & $(0.10)$ \\
\hline \multirow[t]{2}{*}{ Norway } & Less than high-school & - & - & 12.21 & $(0.31)$ & 15.93 & $(0.74)$ & 16.86 & $(1.31)$ & 4.64 & 1.02 \\
\hline & Some college and college grads & - & - & 14.47 & $(0.61)$ & 13.68 & $(0.45)$ & 18.09 & $(0.68)$ & 3.62 & $(0.53)$ \\
\hline \multirow[t]{4}{*}{ The United Kingdom } & Less than high-school & 7.42 & $(0.24)$ & 14.06 & $(0.33)$ & 10.23 & $(2.29)$ & 17.09 & $(0.43)$ & 9.67 & 3.06 \\
\hline & Some college and college grads & 9.51 & $(0.65)$ & 15.13 & $(0.53)$ & 10.34 & $(1.25)$ & 16.13 & $(0.45)$ & 6.61 & $(<0.01)$ \\
\hline & & \multicolumn{4}{|c|}{ Panel B: Women } & & & & & & \\
\hline & & Mean & $\underline{\text { SD }}$ & $\underline{\text { Mean }}$ & $\underline{\text { SD }}$ & $\underline{\text { Mean }}$ & $\underline{\text { SD }}$ & $\underline{\text { Mean }}$ & $\underline{\text { SD }}$ & & \\
\hline \multirow[t]{2}{*}{ Australia } & Less than high-school & 36.50 & $(1.07)$ & 34.24 & $(0.89)$ & 33.04 & $(0.30)$ & - & - & -3.46 & 6.00 \\
\hline & Some college and college grads & 36.57 & $(2.25)$ & 28.23 & $(0.85)$ & 27.12 & $(0.40)$ & - & - & -9.46 & $(0.02)$ \\
\hline \multirow[t]{2}{*}{ Canada } & Less than high-school & 36.04 & $(0.61)$ & 32.45 & $(0.38)$ & 30.39 & $(0.41)$ & - & - & -5.66 & -2.27 \\
\hline & Some college and college grads & 27.88 & $(0.92)$ & 24.22 & $(0.33)$ & 24.49 & $(0.23)$ & - & - & -3.39 & $(0.06)$ \\
\hline \multirow[t]{2}{*}{ Finland } & Less than high-school & 29.73 & $(0.34)$ & 28.70 & $(0.36)$ & 26.50 & $(0.41)$ & - & - & -3.24 & -5.45 \\
\hline & Some college and college grads & 20.42 & $(0.65)$ & 22.91 & $(0.64)$ & 22.63 & $(0.82)$ & - & - & 2.21 & $(<0.01)$ \\
\hline \multirow[t]{2}{*}{ France } & Less than high-school & 37.99 & $(0.49)$ & - & - & 36.49 & $(0.54)$ & - & - & -1.50 & 0.95 \\
\hline & Some college and college grads & 27.71 & $(1.12)$ & - & - & 25.26 & $(0.31)$ & - & - & -2.45 & $(0.49)$ \\
\hline \multirow[t]{2}{*}{ The Netherlands } & Less than high-school & 36.33 & $(0.36)$ & 36.39 & $(0.19)$ & 34.31 & $(0.25)$ & 33.30 & $(0.39)$ & -3.03 & 8.09 \\
\hline & Some college and college grads & 33.97 & $(1.28)$ & 25.90 & $(0.53)$ & 22.68 & $(0.35)$ & 22.84 & $(0.29)$ & -11.12 & $(<0.01)$ \\
\hline \multirow[t]{2}{*}{ Norway } & Less than high-school & - & - & 31.81 & $(0.36)$ & 28.70 & $(0.73)$ & 26.38 & $(1.25)$ & -5.43 & -4.27 \\
\hline & Some college and college grads & - & - & 25.02 & $(0.65)$ & 23.62 & $(0.51)$ & 23.86 & $(0.66)$ & -1.16 & $(<0.01)$ \\
\hline \multirow[t]{2}{*}{ The United Kingdom } & Less than high-school & 31.24 & $(0.34)$ & 33.68 & $(0.30)$ & 27.42 & $(3.01)$ & 31.94 & $(0.43)$ & 0.70 & 4.97 \\
\hline & Some college and college grads & 29.10 & $(0.91)$ & 27.11 & $(0.52)$ & 17.61 & $(1.46)$ & 24.83 & $(0.43)$ & -4.27 & $(<0.01)$ \\
\hline
\end{tabular}

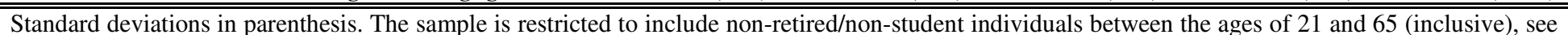

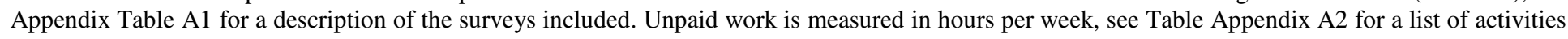

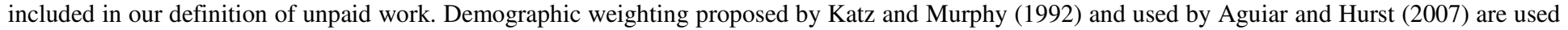

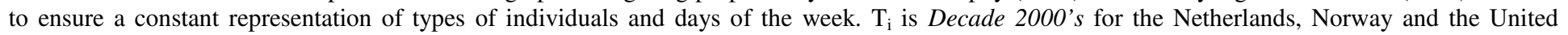

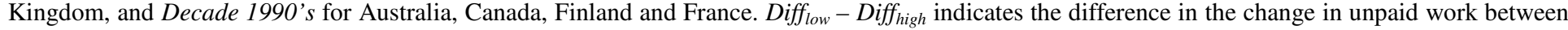

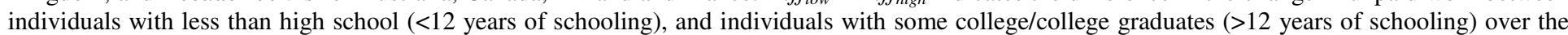
relevant period, $\mathrm{p}$-value of such difference in parentheses. 
Table 13. Inequality in child care over the period, low and highly-educated (men and women)

\begin{tabular}{|c|c|c|c|c|c|c|c|c|c|c|c|}
\hline \multirow[t]{2}{*}{$\begin{array}{l}\text { Time-use category } \\
\text { (hours per week) }\end{array}$} & & \multicolumn{2}{|c|}{ DECADE 70's } & \multicolumn{2}{|c|}{ DECADE 80's } & \multicolumn{2}{|c|}{ DECADE 90's } & \multicolumn{2}{|c|}{ DECADE 00's } & \multirow[t]{2}{*}{ Diff. } & \multirow[t]{2}{*}{$\begin{array}{c}\text { Cum. } \\
\text { Diff }\end{array}$} \\
\hline \multirow{2}{*}{\multicolumn{12}{|c|}{\begin{tabular}{ll}
\multicolumn{2}{l}{ Panel A: Men } \\
SD & Mean
\end{tabular}}} \\
\hline & & & & & & & & & & & \\
\hline Australia & Less than high-school & 0.70 & $(0.16)$ & 1.73 & $(0.25)$ & 1.87 & $(0.13)$ & - & - & 1.18 & 0.52 \\
\hline & Some college and college grads & 2.34 & $(0.82)$ & 2.38 & $(0.22)$ & 3.00 & $(0.16)$ & - & - & 0.66 & $(0.54)$ \\
\hline \multirow[t]{2}{*}{ Canada } & Less than high-school & 1.30 & $(0.14)$ & 1.75 & $(0.13)$ & 2.05 & $(0.14)$ & - & - & 0.76 & -0.39 \\
\hline & Some college and college grads & 1.91 & $(0.25)$ & 2.27 & $(0.11)$ & 3.07 & $(0.10)$ & - & - & 1.15 & $(0.23)$ \\
\hline \multirow[t]{2}{*}{ Finland } & Less than high-school & 0.97 & $(0.07)$ & 0.98 & $(0.07)$ & 1.79 & $(0.14)$ & - & - & 0.81 & -0.11 \\
\hline & Some college and college grads & 2.42 & $(0.26)$ & 3.06 & $(0.29)$ & 3.34 & $(0.39)$ & - & - & 0.92 & $(0.83)$ \\
\hline \multirow[t]{2}{*}{ France } & Less than high-school & 1.09 & $(0.09)$ & - & - & 1.50 & $(0.14)$ & - & - & 0.40 & 0.34 \\
\hline & Some college and college grads & 2.26 & $(0.28)$ & - & - & 2.32 & $(0.11)$ & - & - & 0.06 & $(0.32)$ \\
\hline \multirow[t]{2}{*}{ The Netherlands } & Less than high-school & 1.99 & $(0.17)$ & 1.89 & $(0.08)$ & 2.22 & $(0.12)$ & 1.58 & $(0.13)$ & -0.41 & -0.58 \\
\hline & Some college and college grads & 2.95 & $(0.52)$ & 2.89 & $(0.18)$ & 3.16 & $(0.18)$ & 3.12 & $(0.13)$ & 0.17 & $(0.31)$ \\
\hline \multirow[t]{2}{*}{ Norway } & Less than high-school & - & - & 1.97 & $(0.10)$ & 2.15 & $(0.23)$ & 1.80 & $(0.42)$ & -0.18 & -0.05 \\
\hline & Some college and college grads & - & - & 4.24 & $(0.30)$ & 3.13 & $(0.22)$ & 4.10 & $(0.31)$ & -0.13 & $(0.94)$ \\
\hline \multirow[t]{2}{*}{ The United Kingdom } & Less than high-school & 0.62 & $(0.05)$ & 1.48 & $(0.10)$ & 0.59 & $(0.44)$ & 1.84 & $(0.13)$ & 1.22 & -0.70 \\
\hline & Some college and college grads & 0.46 & $(0.09)$ & 2.51 & $(0.21)$ & 4.18 & $(1.00)$ & 2.38 & $(0.18)$ & 1.92 & $(<0.01)$ \\
\hline \multicolumn{12}{|c|}{ Panel B: Women } \\
\hline \multirow{3}{*}{ Australia } & & $\underline{\text { Mean }}$ & $\underline{\mathbf{S D}}$ & $\underline{\text { Mean }}$ & $\underline{\text { SD }}$ & Mean & $\underline{\mathbf{S D}}$ & Mean & $\underline{\text { SD }}$ & & \\
\hline & Less than high-school & 4.23 & $(0.47)$ & 6.45 & $(0.53)$ & 6.44 & $(0.20)$ & - & - & 2.21 & 2.23 \\
\hline & Some college and college grads & 9.59 & $(1.21)$ & 10.80 & $(0.71)$ & 9.57 & $(0.36)$ & - & - & -0.02 & $(0.10)$ \\
\hline \multirow[t]{2}{*}{ Canada } & Less than high-school & 7.64 & $(0.31)$ & 5.49 & $(0.21)$ & 5.77 & $(0.24)$ & - & - & -1.88 & -3.00 \\
\hline & Some college and college grads & 5.93 & $(0.43)$ & 6.20 & $(0.19)$ & 7.04 & $(0.16)$ & - & - & 1.12 & $(<0.01)$ \\
\hline \multirow[t]{2}{*}{ Finland } & Less than high-school & 2.70 & $(0.13)$ & 2.46 & $(0.16)$ & 4.60 & $(0.25)$ & - & - & 1.90 & 1.35 \\
\hline & Some college and college grads & 5.50 & $(0.45)$ & 6.56 & $(0.56)$ & 6.05 & $(0.58)$ & - & - & 0.55 & $(0.09)$ \\
\hline \multirow[t]{2}{*}{ France } & Less than high-school & 5.39 & $(0.24)$ & - & - & 7.23 & $(0.33)$ & - & - & 1.84 & 2.17 \\
\hline & Some college and college grads & 7.00 & $(0.70)$ & - & - & 6.67 & $(0.18)$ & - & - & -0.33 & $(0.01)$ \\
\hline \multirow[t]{2}{*}{ The Netherlands } & Less than high-school & 5.71 & $(0.22)$ & 6.00 & $(0.14)$ & 5.61 & $(0.16)$ & 5.08 & $(0.21)$ & 5.01 & 2.24 \\
\hline & Some college and college grads & 6.21 & $(0.70)$ & 6.85 & $(0.45)$ & 6.49 & $(0.29)$ & 5.86 & $(0.18)$ & 2.77 & $(0.73)$ \\
\hline \multirow[t]{2}{*}{ Norway } & Less than high-school & - & - & 5.03 & $(0.19)$ & 4.40 & $(0.38)$ & 3.76 & $(0.57)$ & -1.27 & -2.73 \\
\hline & Some college and college grads & - & - & 10.68 & $(0.51)$ & 9.82 & $(0.51)$ & 12.13 & $(0.57)$ & 1.46 & $(0.03)$ \\
\hline \multirow[t]{2}{*}{ The United Kingdom } & Less than high-school & 2.13 & $(0.10)$ & 4.57 & $(0.15)$ & 2.62 & $(1.32)$ & 3.87 & $(0.19)$ & 1.74 & -1.11 \\
\hline & Some college and college grads & 2.53 & $(0.26)$ & 5.73 & $(0.33)$ & 8.01 & $(1.41)$ & 5.38 & $(0.27)$ & 2.85 & $(<0.01)$ \\
\hline
\end{tabular}

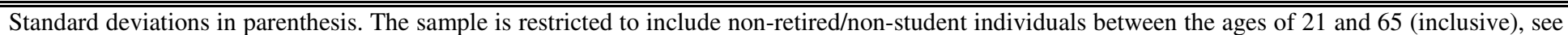

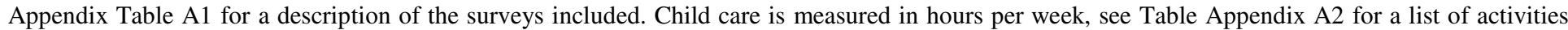

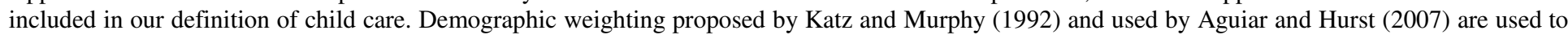

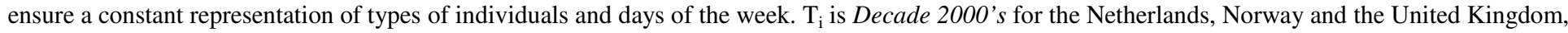

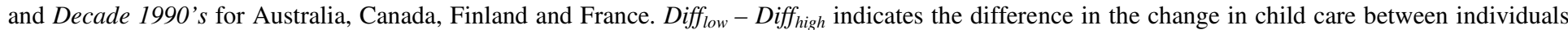

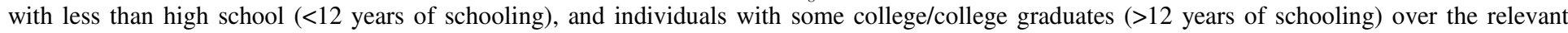
period, p-value of such difference in parentheses. 
Table 14. Difference in the change of time devoted to leisure activities over the period between educational groups (men)

\begin{tabular}{|c|c|c|c|c|c|c|c|c|c|c|c|}
\hline Leisure (hours per week) & & $\begin{array}{c}\text { Total } \\
\text { Leisure }\end{array}$ & $\begin{array}{c}\text { TV } \\
\text { Watching }\end{array}$ & Reading & Eating & Socializing & Sports & Sleeping & $\begin{array}{c}\text { Personal } \\
\text { Care }\end{array}$ & Gardening & $\begin{array}{c}\text { Other } \\
\text { Activities }\end{array}$ \\
\hline Australia & $\begin{array}{l}\text { Less than high-school } \\
\text { Some college and college grads }\end{array}$ & $\begin{array}{c}5.96 \\
(0.02) \\
2.09 \\
(0.61)\end{array}$ & $\begin{array}{c}1.43 \\
(0.18) \\
5.18 \\
(0.00)\end{array}$ & $\begin{array}{l}-1.08 \\
(0.03) \\
-2.86 \\
(0.01)\end{array}$ & $\begin{array}{l}-1.85 \\
(0.00) \\
-1.30 \\
(0.08)\end{array}$ & $\begin{array}{l}2.11 \\
(0.01) \\
-1.53 \\
(0.50)\end{array}$ & $\begin{array}{c}2.22 \\
(0.00) \\
2.59 \\
(0.00)\end{array}$ & $\begin{array}{l}3.29 \\
(0.00) \\
-0.05 \\
(0.97)\end{array}$ & $\begin{array}{c}1.10 \\
(0.00) \\
0.63 \\
(0.05)\end{array}$ & $\begin{array}{c}0.11 \\
(0.84) \\
0.60 \\
(0.36)\end{array}$ & $\begin{array}{l}-1.38 \\
(0.20) \\
-0.84 \\
(0.69)\end{array}$ \\
\hline Canada & $\begin{array}{l}\text { Less than high-school } \\
\text { Some college and college grads }\end{array}$ & $\begin{array}{l}7.12 \\
(0.00) \\
-1.67 \\
(0.24)\end{array}$ & $\begin{array}{l}(0.00) \\
2.04 \\
(0.01)\end{array}$ & $\begin{array}{l}-1.06 \\
(0.00) \\
-1.61 \\
(0.00)\end{array}$ & $\begin{array}{l}-1.85 \\
(0.00) \\
-2.38 \\
(0.00)\end{array}$ & $\begin{array}{c}3.19 \\
(0.00) \\
1.33 \\
(0.01)\end{array}$ & $\begin{array}{c}2.54 \\
(0.00) \\
1.91 \\
(0.00)\end{array}$ & $\begin{array}{c}1.41 \\
(0.01) \\
0.41 \\
(0.49)\end{array}$ & $\begin{array}{l}-3.14 \\
(0.00) \\
-2.87 \\
(0.00)\end{array}$ & $\begin{array}{c}1.50 \\
(0.00) \\
0.96 \\
(0.00)\end{array}$ & $\begin{array}{l}-1.03 \\
(0.06) \\
-1.42 \\
(0.02)\end{array}$ \\
\hline Finland & $\begin{array}{l}\text { Less than high-school } \\
\text { Some college and college grads }\end{array}$ & $\begin{array}{c}6.49 \\
(0.00) \\
6.32 \\
(0.00)\end{array}$ & $\begin{array}{c}7.09 \\
(0.00) \\
6.93 \\
(0.00)\end{array}$ & $\begin{array}{l}-1.52 \\
(0.00) \\
-0.68 \\
(0.22)\end{array}$ & $\begin{array}{l}-3.27 \\
(0.00) \\
-2.60 \\
(0.00)\end{array}$ & $\begin{array}{l}-0.38 \\
(0.21) \\
-1.52 \\
(0.03)\end{array}$ & $\begin{array}{c}0.83 \\
(0.01) \\
1.22 \\
(0.04)\end{array}$ & $\begin{array}{l}1.81 \\
(0.00) \\
3.33 \\
(0.00)\end{array}$ & $\begin{array}{l}-0.27 \\
(0.03) \\
-0.20 \\
(0.38)\end{array}$ & $\begin{array}{c}1.31 \\
(0.00) \\
0.65 \\
(0.00)\end{array}$ & $\begin{array}{l}-0.76 \\
(0.04) \\
-1.76 \\
(0.05)\end{array}$ \\
\hline France & $\begin{array}{l}\text { Less than high-school } \\
\text { Some college and college grads }\end{array}$ & $\begin{array}{l}0.21 \\
(0.88) \\
-3.52 \\
(0.03)\end{array}$ & $\begin{array}{c}6.40 \\
(0.00) \\
3.31 \\
(0.00)\end{array}$ & $\begin{array}{l}-1.68 \\
(0.00) \\
-1.84 \\
(0.00)\end{array}$ & $\begin{array}{c}0.45 \\
(0.17) \\
1.09 \\
(0.00)\end{array}$ & $\begin{array}{l}-2.54 \\
(0.00) \\
-4.56 \\
(0.00)\end{array}$ & $\begin{array}{c}1.00 \\
(0.01) \\
1.33 \\
(0.00)\end{array}$ & $\begin{array}{l}3.30 \\
(0.00) \\
1.08 \\
(0.18)\end{array}$ & $\begin{array}{l}-4.36 \\
(0.00) \\
-3.64 \\
(0.00)\end{array}$ & $\begin{array}{c}-0.40 \\
(0.11) \\
0.54 \\
(0.00)\end{array}$ & $\begin{array}{l}-2.18 \\
(0.00) \\
-1.84 \\
(0.01)\end{array}$ \\
\hline The Netherlands & $\begin{array}{l}\text { Less than high-school } \\
\text { Some college and college grads }\end{array}$ & $\begin{array}{l}-2.67 \\
(0.03) \\
-7.53 \\
(0.00)\end{array}$ & $\begin{array}{c}0.39 \\
(0.38) \\
0.46 \\
(0.34)\end{array}$ & $\begin{array}{l}-2.48 \\
(0.00) \\
-3.40 \\
(0.00)\end{array}$ & $\begin{array}{c}-0.57 \\
(0.01) \\
-0.36 \\
(0.34)\end{array}$ & $\begin{array}{c}-2.15 \\
(0.00) \\
-4.01 \\
(0.00)\end{array}$ & $\begin{array}{c}-0.11 \\
(0.66) \\
0.65 \\
(0.04)\end{array}$ & $\begin{array}{c}0.97 \\
(0.10) \\
-0.27 \\
(0.70)\end{array}$ & $\begin{array}{c}-0.78 \\
(0.28) \\
0.00 \\
(1.00)\end{array}$ & $\begin{array}{c}-0.25 \\
(0.06) \\
-0.62 \\
(0.09)\end{array}$ & $\begin{array}{c}2.24 \\
(0.00) \\
-0.34 \\
(0.61)\end{array}$ \\
\hline Norway & $\begin{array}{l}\text { Less than high-school } \\
\text { Some college and college grads }\end{array}$ & $\begin{array}{c}-5.24 \\
(0.03) \\
-4.05 \\
(0.01)\end{array}$ & $\begin{array}{c}4.29 \\
(0.00) \\
4.04 \\
(0.00)\end{array}$ & $\begin{array}{c}-2.18 \\
(0.00) \\
-2.07 \\
(0.00)\end{array}$ & $\begin{array}{c}-1.23 \\
(0.00) \\
-1.42 \\
(0.00)\end{array}$ & $\begin{array}{c}-3.48 \\
(0.00) \\
-1.39 \\
(0.04)\end{array}$ & $\begin{array}{c}0.47 \\
(0.55) \\
-0.32 \\
(0.40)\end{array}$ & $\begin{array}{c}-0.69 \\
(0.50) \\
-0.17 \\
(0.78)\end{array}$ & $\begin{array}{c}-1.30 \\
(0.00) \\
-1.97 \\
(0.00)\end{array}$ & $\begin{array}{c}-0.10 \\
(0.78) \\
-0.14 \\
(0.52)\end{array}$ & $\begin{array}{c}-0.98 \\
(0.22) \\
-1.43 \\
(0.03)\end{array}$ \\
\hline The United Kingdom & $\begin{array}{l}\text { Less than high-school } \\
\text { Some college and college grads }\end{array}$ & $\begin{array}{c}4.08 \\
(0.00) \\
0.47 \\
(0.75)\end{array}$ & $\begin{array}{c}2.00 \\
(0.00) \\
2.10 \\
(0.00)\end{array}$ & $\begin{array}{c}-0.21 \\
(0.15) \\
0.50 \\
(0.08)\end{array}$ & $\begin{array}{c}-1.21 \\
(0.00) \\
-2.30 \\
(0.00)\end{array}$ & $\begin{array}{c}-2.12 \\
(0.00) \\
-1.17 \\
(0.07)\end{array}$ & $\begin{array}{c}1.77 \\
(0.00) \\
1.59 \\
(0.00)\end{array}$ & $\begin{array}{c}2.93 \\
(0.00) \\
0.04 \\
(0.96)\end{array}$ & $\begin{array}{c}-1.14 \\
(0.00) \\
-0.89 \\
(0.00)\end{array}$ & $\begin{array}{c}0.75 \\
(0.00) \\
-0.06 \\
(0.84)\end{array}$ & $\begin{array}{l}-2.03 \\
(0.00) \\
-3.28 \\
(0.00)\end{array}$ \\
\hline
\end{tabular}

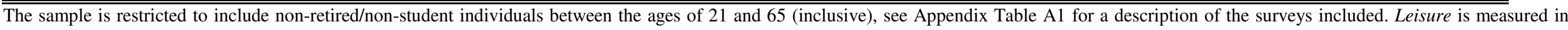

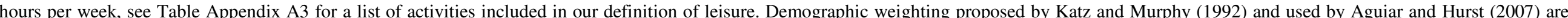

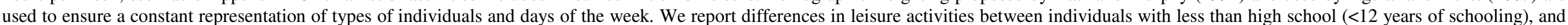
individuals with some college/college graduates ( $>12$ years of schooling). p-value of the difference in parentheses. 
Table 15. Difference in the change of time devoted to leisure activities over the period between educational groups (women)

\begin{tabular}{|c|c|c|c|c|c|c|c|c|c|c|c|}
\hline Leisure (hours per week) & & $\begin{array}{c}\text { Total } \\
\text { Leisure }\end{array}$ & $\begin{array}{c}\text { TV } \\
\text { Watching } \\
\end{array}$ & Reading & Eating & Socializing & Sports & Sleeping & $\begin{array}{c}\begin{array}{c}\text { Personal } \\
\text { Care }\end{array} \\
\end{array}$ & Gardening & $\begin{array}{c}\text { Other } \\
\text { Activities }\end{array}$ \\
\hline Australia & $\begin{array}{l}\text { Less than high-school } \\
\text { Some college and college grads }\end{array}$ & $\begin{array}{c}0.74 \\
(0.62) \\
-2.49 \\
(0.30)\end{array}$ & $\begin{array}{c}-1.58 \\
(0.03) \\
0.79 \\
(0.44)\end{array}$ & $\begin{array}{l}-0.31 \\
(0.27) \\
-1.30 \\
(0.02)\end{array}$ & $\begin{array}{l}-2.50 \\
(0.00) \\
-4.53 \\
(0.00)\end{array}$ & $\begin{array}{c}2.78 \\
(0.00) \\
1.08 \\
(0.36)\end{array}$ & $\begin{array}{c}1.45 \\
(0.00) \\
1.92 \\
(0.00)\end{array}$ & $\begin{array}{c}-1.55 \\
(0.05) \\
0.31 \\
(0.81)\end{array}$ & $\begin{array}{c}1.19 \\
(0.00) \\
1.27 \\
(0.00)\end{array}$ & $\begin{array}{c}0.90 \\
(0.00) \\
0.58 \\
(0.02)\end{array}$ & $\begin{array}{c}0.13 \\
(0.87) \\
-2.14 \\
(0.12)\end{array}$ \\
\hline Canada & $\begin{array}{l}\text { Less than high-school } \\
\text { Some college and college grads }\end{array}$ & $\begin{array}{l}4.65 \\
(0.00) \\
-3.11 \\
(0.01)\end{array}$ & $\begin{array}{c}3.80 \\
(0.00) \\
1.99 \\
(0.00)\end{array}$ & $\begin{array}{l}-0.28 \\
(0.11) \\
-0.70 \\
(0.02)\end{array}$ & $\begin{array}{l}-2.75 \\
(0.00) \\
-2.73 \\
(0.00)\end{array}$ & $\begin{array}{c}2.60 \\
(0.00) \\
1.04 \\
(0.06)\end{array}$ & $\begin{array}{c}1.27 \\
(0.00) \\
1.76 \\
(0.00)\end{array}$ & $\begin{array}{c}1.49 \\
(0.00) \\
0.20 \\
(0.75)\end{array}$ & $\begin{array}{l}-2.27 \\
(0.00) \\
-2.02 \\
(0.00)\end{array}$ & $\begin{array}{c}0.82 \\
(0.00) \\
0.38 \\
(0.00)\end{array}$ & $\begin{array}{l}-0.67 \\
(0.11) \\
-3.22 \\
(0.00)\end{array}$ \\
\hline Finland & $\begin{array}{l}\text { Less than high-school } \\
\text { Some college and college grads }\end{array}$ & $\begin{array}{c}5.73 \\
(0.00) \\
7.83 \\
(0.00)\end{array}$ & $\begin{array}{c}5.16 \\
(0.00) \\
4.40 \\
(0.00)\end{array}$ & $\begin{array}{c}-0.27 \\
(0.13) \\
0.71 \\
(0.10)\end{array}$ & $\begin{array}{c}-2.04 \\
(0.00) \\
-2.32 \\
(0.00)\end{array}$ & $\begin{array}{l}-0.61 \\
(0.05) \\
-1.04 \\
(0.11)\end{array}$ & $\begin{array}{c}1.73 \\
(0.00) \\
1.87 \\
(0.00)\end{array}$ & $\begin{array}{c}1.95 \\
(0.00) \\
2.26 \\
(0.01)\end{array}$ & $\begin{array}{c}0.31 \\
(0.02) \\
0.05 \\
(0.81)\end{array}$ & $\begin{array}{c}1.73 \\
(0.00) \\
1.40 \\
(0.00)\end{array}$ & $\begin{array}{l}-3.26 \\
(0.00) \\
-1.10 \\
(0.23)\end{array}$ \\
\hline France & $\begin{array}{l}\text { Less than high-school } \\
\text { Some college and college grads }\end{array}$ & $\begin{array}{c}3.79 \\
(0.00) \\
-2.75 \\
(0.10)\end{array}$ & $\begin{array}{c}6.43 \\
(0.00) \\
3.49 \\
(0.00)\end{array}$ & $\begin{array}{l}-0.72 \\
(0.00) \\
-1.86 \\
(0.00)\end{array}$ & $\begin{array}{c}0.98 \\
(0.00) \\
0.99 \\
(0.01)\end{array}$ & $\begin{array}{l}-2.52 \\
(0.00) \\
-4.71 \\
(0.00)\end{array}$ & $\begin{array}{c}1.14 \\
(0.00) \\
1.11 \\
(0.00)\end{array}$ & $\begin{array}{c}4.20 \\
(0.00) \\
3.52 \\
(0.00)\end{array}$ & $\begin{array}{l}-4.06 \\
(0.00) \\
-3.98 \\
(0.00)\end{array}$ & $\begin{array}{c}-0.12 \\
(0.38) \\
0.30 \\
(0.04)\end{array}$ & $\begin{array}{l}-2.45 \\
(0.00) \\
-3.66 \\
(0.00)\end{array}$ \\
\hline The Netherlands & $\begin{array}{l}\text { Less than high-school } \\
\text { Some college and college grads }\end{array}$ & $\begin{array}{l}-2.01 \\
(0.00) \\
-5.70 \\
(0.00)\end{array}$ & $\begin{array}{c}2.17 \\
(0.00) \\
0.86 \\
(0.19)\end{array}$ & $\begin{array}{l}-2.93 \\
(0.00) \\
-1.83 \\
(0.00)\end{array}$ & $\begin{array}{c}-0.86 \\
(0.00) \\
-3.10 \\
(0.00)\end{array}$ & $\begin{array}{l}-3.56 \\
(0.00) \\
-2.66 \\
(0.01)\end{array}$ & $\begin{array}{c}0.81 \\
(0.00) \\
0.84 \\
(0.00)\end{array}$ & $\begin{array}{c}2.46 \\
(0.00) \\
0.79 \\
(0.27)\end{array}$ & $\begin{array}{c}0.13 \\
(0.68) \\
1.36 \\
(0.00)\end{array}$ & $\begin{array}{c}0.21 \\
(0.00) \\
-0.28 \\
(0.18)\end{array}$ & $\begin{array}{l}-0.61 \\
(0.07) \\
-2.32 \\
(0.00)\end{array}$ \\
\hline Norway & $\begin{array}{l}\text { Less than high-school } \\
\text { Some college and college grads }\end{array}$ & $\begin{array}{c}2.61 \\
(0.19) \\
-2.32 \\
(0.09)\end{array}$ & $\begin{array}{c}2.53 \\
(0.00) \\
2.60 \\
(0.00)\end{array}$ & $\begin{array}{l}-0.95 \\
(0.01) \\
-0.72 \\
(0.00)\end{array}$ & $\begin{array}{c}-1.62 \\
(0.00) \\
-0.80 \\
(0.00)\end{array}$ & $\begin{array}{l}-0.58 \\
(0.59) \\
-2.14 \\
(0.01)\end{array}$ & $\begin{array}{c}1.05 \\
(0.07) \\
0.02 \\
(0.95)\end{array}$ & $\begin{array}{l}1.59 \\
(0.19) \\
-0.26 \\
(0.67)\end{array}$ & $\begin{array}{l}-0.55 \\
(0.03) \\
-0.50 \\
(0.01)\end{array}$ & $\begin{array}{l}-0.13 \\
(0.51) \\
-0.73 \\
(0.00)\end{array}$ & $\begin{array}{c}0.83 \\
(0.29) \\
-0.12 \\
(0.81)\end{array}$ \\
\hline The United Kingdom & $\begin{array}{l}\text { Less than high-school } \\
\text { Some college and college grads }\end{array}$ & $\begin{array}{l}-1.63 \\
(0.02) \\
-2.93 \\
(0.03)\end{array}$ & $\begin{array}{c}-0.27 \\
(0.55) \\
1.66 \\
(0.01)\end{array}$ & $\begin{array}{c}0.54 \\
(0.00) \\
0.45 \\
(0.12)\end{array}$ & $\begin{array}{l}-2.10 \\
(0.00) \\
-3.37 \\
(0.00)\end{array}$ & $\begin{array}{l}-3.58 \\
(0.00) \\
-0.97 \\
(0.14)\end{array}$ & $\begin{array}{c}1.28 \\
(0.00) \\
0.94 \\
(0.00)\end{array}$ & $\begin{array}{c}3.85 \\
(0.00) \\
0.45 \\
(0.48)\end{array}$ & $\begin{array}{l}-1.14 \\
(0.00) \\
-0.76 \\
(0.00)\end{array}$ & $\begin{array}{c}0.57 \\
(0.00) \\
-0.52 \\
(0.05)\end{array}$ & $\begin{array}{l}-2.78 \\
(0.00) \\
-4.09 \\
(0.00)\end{array}$ \\
\hline
\end{tabular}

sample is restricted to include non-retired/non-student individuals between the ages of 21 and 65 (inclusive), see Appendix Table A1 for a description of the surveys included. Leisure is in hours per week, see Table Appendix A3 for a list of activities included in our definition of leisure. Demographic weighting proposed by Katz and Murphy (1992) and used by Aguiar an

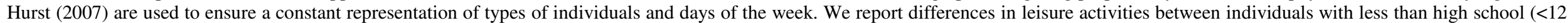
years of schooling), and individuals with some college/college graduates ( $>12$ years of schooling). p-value of the difference in parentheses. 


\section{APPENDIX A}

Table A1. Description of time use surveys

\begin{tabular}{|c|c|c|c|}
\hline 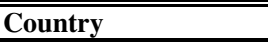 & Year & Survey coverage & Original sample size \\
\hline \multirow{4}{*}{ Australia } & 1974 & Mach 1974 & 2,400 diaries \\
\hline & 1987 & 23 May - 4 June 1987 & 3,222 diaries \\
\hline & 1992 & February 24 - March 7, May 25 - June 6, September 28 - October 10, November 23 - December 5 & 13,724 diaries \\
\hline & 1997 & 27 January - 8 February, 21 April - 3 May, 23 June - 5 July, 27 October - 8 November 1997 & 14,012 diaries \\
\hline \multirow[t]{5}{*}{ Canada } & 1971 & 27 January - 8 February, 21 April - 3 May, 23 June - 5 July, 27 October - 8 November 1997 & 2,138 diaries \\
\hline & 1981 & 11 September to 29 October, November 1981 & 2,658 diaries \\
\hline & 1986 & 25 October 1986 - 22 December & 9.618 diaries \\
\hline & 1992 & January - December 1992 & 8,936 diaries \\
\hline & 1998 & January - December 1998 & 10,726 diaries \\
\hline \multirow[t]{3}{*}{ Finland } & 1979 & September - November 1979 & 11,908 diaries \\
\hline & 1987 & April 1987 - March 1988 & 15,219 diaries \\
\hline & 1999 & March 1999 to February 2000; a small number of diaries collected in February 1999 and March 2000 & 10,076 diaries \\
\hline \multirow[t]{3}{*}{ France } & 1965 & May 1965-April 1966 & 2,868 diaries \\
\hline & 1974 & May 1974-April 1975 & 6,642 diaries \\
\hline & 1998 & 16 February $1998-14$ February 1999 & 15,430 diaries \\
\hline \multirow{7}{*}{ The Netherlands } & 1975 & Oct-75 & 7,926 diaries \\
\hline & 1980 & Oct-80 & 16,569 diaries \\
\hline & 1985 & Oct-85 & 20,667 diaries \\
\hline & 1990 & Oct-90 & 21,852 diaries \\
\hline & 1995 & Oct-95 & 20,610 diaries \\
\hline & 2000 & Oct-00 & 12,532 diaries \\
\hline & 2005 & Oct-05 & 13,142 diaries \\
\hline \multirow{4}{*}{ Norway } & 1971 & September 1971 - August 1972 & 6,516 diaries \\
\hline & 1981 & October 1980 - September 1981 & 6,068 diaries \\
\hline & 1990 & 1 February 1990 and 30 January 1991 & 6,129 diaries \\
\hline & 2000 & February 2000 - February 2001 & 6,628 diaries \\
\hline \multirow{5}{*}{ The United Kingdom } & 1975 & 14-20 August, 4-10 September 1974; 12-18 February, 26 February - 4 March 1975 & 19,490 diaries \\
\hline & 1983 & Autumn 1983, Winter 1984 & 9,206 diaries \\
\hline & 1987 & Jul-87 & 8,854 diaries \\
\hline & 1995 & 1995 & 1,906 diaries \\
\hline & 2000 & June 2000 - August 2001 & 19,400 diaries \\
\hline
\end{tabular}
that we use in our main empirical analysis. We restrict the sample to include only those individuals who had time diaries that summed to a complete day (i.e., 1440 minutes). All surveys include sample weights, and weights are adjusted to ensure each day of the week and each survey are uniformly represented. 
Table A2. Time use activities

\begin{tabular}{|c|c|c|c|c|c|}
\hline & Time use categories & Paid Work & "Unpaid Work & Child Care & Leisure \\
\hline AV1 & paid work & $\mathrm{X}$ & - & - & - \\
\hline AV2 & paid work at home & $\mathrm{X}$ & - & - & - \\
\hline AV3 & second job & $\mathrm{X}$ & - & - & - \\
\hline AV4 & school/classes & $\mathrm{X}$ & - & - & - \\
\hline AV5 & travel to/from work & $X$ & - & - & - \\
\hline AV6 & cooking, washing up & - & $\mathrm{X}$ & - & - \\
\hline AV7 & housework & - & $\mathrm{X}$ & - & - \\
\hline AV8 & odd jobs & - & $\mathrm{X}$ & - & - \\
\hline AV9 & gardening & - & - & - & $\mathrm{X}$ \\
\hline AV10 & shopping & - & $\mathrm{X}$ & - & - \\
\hline AV11 & Child $\backslash-\{-\}$ Care & - & - & $X$ & - \\
\hline AV12 & domestic travel & - & $\mathrm{X}$ & - & - \\
\hline AV13 & dressing/toilet & - & - & - & $\mathrm{X}$ \\
\hline AV14 & personal services & - & - & - & $\mathrm{X}$ \\
\hline AV15 & meals, snacks & - & - & - & $\mathrm{X}$ \\
\hline AV16 & sleep & - & - & - & $\mathrm{X}$ \\
\hline AV17 & leisure travel & - & - & - & $\mathrm{X}$ \\
\hline AV18 & excursions & - & - & - & $\mathrm{X}$ \\
\hline AV19 & active sport & - & - & - & $\mathrm{X}$ \\
\hline AV20 & passive sport & - & - & - & $\mathrm{X}$ \\
\hline AV21 & walks & - & - & - & $\mathrm{X}$ \\
\hline AV22 & religious activities & - & - & - & - \\
\hline AV23 & civic duties & - & - & - & - \\
\hline AV24 & cinema, theatre & - & - & - & $\mathrm{X}$ \\
\hline AV25 & dances, parties & - & - & - & $\mathrm{X}$ \\
\hline AV26 & social club & - & - & - & $\mathrm{X}$ \\
\hline AV27 & pub & - & - & - & $\mathrm{X}$ \\
\hline AV28 & restaurant & - & - & - & $\mathrm{X}$ \\
\hline AV29 & visit friends & - & - & - & $\mathrm{X}$ \\
\hline AV30 & listen to radio & - & - & - & $\mathrm{X}$ \\
\hline AV31 & TV, video & - & - & - & $\mathrm{X}$ \\
\hline AV32 & listen to tapes, etc. & - & - & - & $\mathrm{X}$ \\
\hline AV33 & study & $\mathrm{X}$ & - & - & - \\
\hline AV34 & reading books & - & - & - & $\mathrm{X}$ \\
\hline AV35 & reading papers, magazines & - & - & - & $\mathrm{X}$ \\
\hline AV36 & relaxing & - & - & - & $\mathrm{X}$ \\
\hline AV37 & conversation & - & - & - & $\mathrm{X}$ \\
\hline AV38 & entertaining friends & - & - & - & $\mathrm{X}$ \\
\hline AV39 & knitting, sewing, etc. & - & - & - & $\mathrm{X}$ \\
\hline AV40 & other hobbies and pastimes & - & - & - & $\mathrm{X}$ \\
\hline
\end{tabular}

Source: Multinational Time Use Study (MTUS, www.timeuse.org) version 553 and harmonized surveys by authors (see Appendix Table A1 for a description of the surveys included). 
Table A3. Leisure activities

\begin{tabular}{|c|c|c|c|c|c|c|c|c|c|c|}
\hline AV CODE & Classification & $\begin{array}{c}\text { TV } \\
\text { Watching } \\
\end{array}$ & Reading & Eating & Socializing & Sports & Sleep & $\begin{array}{c}\text { Personal } \\
\text { Care } \\
\end{array}$ & Gardening & $\begin{array}{c}\text { Other } \\
\text { Activities }\end{array}$ \\
\hline 9 & Gardening & - & - & - & - & - & - & - & $\mathrm{X}$ & - \\
\hline 13 & Dress/personal care & - & - & - & - & - & - & $\mathrm{X}$ & - & - \\
\hline 15 & Meals and snacks & - & - & $\mathrm{X}$ & - & - & - & - & - & - \\
\hline 16 & Sleep & - & - & - & - & - & $X$ & - & - & - \\
\hline 17 & Free time travel & - & - & - & - & - & - & - & - & $\mathrm{X}$ \\
\hline 18 & Excursions & - & - & - & - & - & - & - & - & $\mathrm{X}$ \\
\hline 19 & Active sports participation & - & - & - & - & $X$ & - & - & - & - \\
\hline 20 & Passive sports participation & - & - & - & - & $X$ & - & - & - & - \\
\hline 21 & Walking & - & - & - & - & $X$ & - & - & - & - \\
\hline 24 & Cinema or theatre & - & - & - & - & - & - & - & - & $X$ \\
\hline 25 & Dances or parties & - & - & - & $\mathrm{X}$ & - & - & - & - & - \\
\hline 26 & Social clubs & - & - & - & $\mathrm{X}$ & - & - & - & - & - \\
\hline 27 & Pubs & - & - & - & - & - & - & - & - & $\mathrm{X}$ \\
\hline 28 & Restaurants & - & - & - & $\mathrm{X}$ & - & - & - & - & - \\
\hline 30 & Listen to radio & - & - & - & - & - & - & - & - & $X$ \\
\hline 31 & Watch television or video & $\mathrm{X}$ & - & - & - & - & - & - & - & - \\
\hline 32 & Listen to records, tapes, cds & - & - & - & - & - & - & - & - & $\mathrm{X}$ \\
\hline 34 & Read books & - & $\mathrm{X}$ & - & - & - & - & - & - & - \\
\hline 35 & Read papers, magazines & - & $X$ & - & - & - & - & - & - & - \\
\hline 36 & Relax & - & - & - & - & - & - & - & - & $X$ \\
\hline 37 & Conversation & - & - & - & $\mathrm{X}$ & - & - & - & - & - \\
\hline 38 & Entertain friends at home & - & - & - & $\mathrm{X}$ & - & - & - & - & - \\
\hline 39 & Knit, sew & - & - & - & - & - & - & - & - & $\mathrm{X}$ \\
\hline 40 & Other leisure & - & - & - & - & - & - & - & - & $X$ \\
\hline
\end{tabular}




\section{APPENDIX B: Demographic Weighting}

We report trends over the last decades holding constant the demographic composition of the sample, following Aguiar and Hurst (2007) Specifically, we divide the sample into demographic cells defined by five age groups $(21-29,30-39,40-49,50-59,60-65)$, three education categories (uncompleted secondary or less, completed secondary, above secondary education), two sex categories (male and female), and whether or not there is a child under 18 in the household. We do not create separate cells distinguishing child status for respondents aged sixty to sixty-five due to the small number that have children present in the home. This division yields forty-eight demographic cells for each country. To calculate the constant weights used for our demographic adjustments, we pool together all of our time use data sets for each country, and compute the percentage of the population that resides in each demographic cell for each country. Following Katz and Murphy (1992), we use these fixed weights to calculate weighted means for each activity in each year

Since our analysis is based on gender and educational characteristics, means for each subsample are calculated in a similar manner with the weights scaled to sum to one. For instance, when only gender is considered, we calculate the percentage of men that resides in each demographic cell (according to age range, education, and presence of children), with these percentages summing to one for men in each country. The same applies for women. We refer to this weight as "gender weight". When gender and education are considered at the same time, we calculate the percentage of men that resides in each demographic cell (according to age range and presence of children), with these percentages summing to one for men in each country and educational level. We refer to this weight as "educational weight". We use the "gender weight" when we analyze trends for men and women, while we use the "education weight" when we analyze trends by gender and educational level.

When pooling the surveys together to compute the percent of the population in each of our cells, we used the weights provided by the surveys to ensure the data is representative of the total population. We adjusted these weights so that each day of the week and each survey are equally represented in the overall sample. 


\section{APPENDIX C: Results for alternative definitions of leisure}

Table C1. Trends in different definitions of non-market work (men)

\begin{tabular}{|c|c|c|c|c|c|c|c|c|c|c|}
\hline $\begin{array}{l}\text { Time-use category } \\
\text { (hours per week) }\end{array}$ & \multicolumn{2}{|c|}{ DECADE 70's } & \multicolumn{2}{|c|}{ DECADE 80's } & \multicolumn{2}{|c|}{ DECADE 90's } & \multicolumn{2}{|c|}{ DECADE 00's } & \multirow[t]{2}{*}{ Diff. } & \multirow[t]{2}{*}{ P-Value } \\
\hline \multicolumn{9}{|c|}{ Panel A: Core Market Work (Housework 1) } & & \\
\hline & $\underline{\text { Mean }}$ & $\underline{\text { SD }}$ & $\underline{\text { Mean }}$ & $\underline{\text { SD }}$ & $\underline{\text { Mean }}$ & $\underline{\text { SD }}$ & $\underline{\text { Mean }}$ & $\underline{\text { SD }}$ & & \\
\hline Australia & 6.09 & $(0.48)$ & 7.55 & $(0.34)$ & 9.02 & $(0.15)$ & - & - & 2.93 & $(<0.01)$ \\
\hline Canada & 6.67 & $(0.30)$ & 7.67 & $(0.16)$ & 9.53 & $(0.14)$ & - & - & 2.85 & $(<0.01)$ \\
\hline Finland & 10.34 & $(0.25)$ & 10.37 & $(0.21)$ & 11.04 & $(0.31)$ & - & - & 0.70 & $(0.08)$ \\
\hline France & 6.63 & $(0.19)$ & - & - & 7.68 & $(0.15)$ & - & - & 1.05 & $(<0.01)$ \\
\hline The Netherlands & 7.12 & $(0.36)$ & 8.99 & $(0.16)$ & 9.06 & $(0.15)$ & 8.94 & $(0.14)$ & 1.82 & $(<0.01)$ \\
\hline Norway & 8.74 & $(0.21)$ & 9.50 & $(0.21)$ & 10.97 & $(0.21)$ & 11.10 & $(0.29)$ & 2.36 & $(<0.01)$ \\
\hline The United Kingdom & 5.23 & $(0.17)$ & 9.43 & $(0.18)$ & 8.13 & $(0.58)$ & 10.88 & $(0.20)$ & 5.66 & $(<0.01)$ \\
\hline \multicolumn{11}{|c|}{ Panel B: Core Market Work + Shopping (Housework 2) } \\
\hline & $\underline{\text { Mean }}$ & $\underline{\text { SD }}$ & $\underline{\text { Mean }}$ & $\underline{\text { SD }}$ & $\underline{\text { Mean }}$ & $\underline{\text { SD }}$ & $\underline{\text { Mean }}$ & $\underline{\text { SD }}$ & & \\
\hline Australia & 4.04 & $(0.31)$ & 5.91 & $(0.25)$ & 7.04 & $(0.11)$ & - & - & 2.99 & $(<0.01)$ \\
\hline Canada & 5.51 & $(0.23)$ & 7.54 & $(0.14)$ & 7.87 & $(0.11)$ & - & - & 2.36 & $(<0.01)$ \\
\hline Finland & 6.38 & $(0.14)$ & 6.74 & $(0.14)$ & 7.58 & $(0.20)$ & - & - & 1.21 & $(<0.01)$ \\
\hline France & 6.75 & $(0.20)$ & - & - & 7.00 & $(0.12)$ & - & - & 0.26 & $(0.27)$ \\
\hline The Netherlands & 5.37 & $(0.29)$ & 6.64 & $(0.13)$ & 7.27 & $(0.12)$ & 7.17 & $(0.10)$ & 1.79 & $(<0.01)$ \\
\hline Norway & 5.47 & $(0.14)$ & 6.71 & $(0.15)$ & 6.12 & $(0.12)$ & 9.62 & $(0.23)$ & 4.14 & $(<0.01)$ \\
\hline The United Kingdom & 3.30 & $(0.11)$ & 7.85 & $(0.15)$ & 7.58 & $(0.47)$ & 9.30 & $(0.16)$ & 6.01 & $(<0.01)$ \\
\hline \multicolumn{11}{|c|}{ Panel C: Core Market Work + Shopping + Odd jobs (Housework 3) } \\
\hline & Mean & $\underline{\text { SD }}$ & Mean & $\underline{\text { SD }}$ & Mean & $\underline{\text { SD }}$ & Mean & $\underline{\text { SD }}$ & & \\
\hline Australia & 7.90 & $(0.52)$ & 9.33 & $(0.38)$ & 11.11 & $(0.16)$ & - & - & 3.21 & $(<0.01)$ \\
\hline Canada & 9.03 & $(0.33)$ & 10.86 & $(0.19)$ & 12.02 & $(0.15)$ & - & - & 2.99 & $(<0.01)$ \\
\hline Finland & 12.65 & $(0.26)$ & 12.81 & $(0.23)$ & 13.77 & $(0.33)$ & - & - & 1.12 & $(<0.01)$ \\
\hline France & 8.81 & $(0.23)$ & - & - & 10.36 & $(0.17)$ & - & - & 1.55 & $(<0.01)$ \\
\hline The Netherlands & 9.05 & $(0.40)$ & 11.09 & $(0.18)$ & 11.21 & $(0.16)$ & 11.33 & $(0.16)$ & 2.28 & $(<0.01)$ \\
\hline Norway & 10.22 & $(0.22)$ & 11.23 & $(0.22)$ & 12.75 & $(0.22)$ & 13.22 & $(0.31)$ & 3.00 & $(<0.01)$ \\
\hline The United Kingdom & 6.81 & $(0.19)$ & 11.99 & $(0.21)$ & 10.83 & $(0.70)$ & 13.67 & $(0.23)$ & 6.86 & $(<0.01)$ \\
\hline \multicolumn{11}{|c|}{ Panel D: Core Market Work + Shopping + Odd jobs + Domestic travel (Housework 4) } \\
\hline & Mean & $\underline{\mathbf{S D}}$ & Mean & $\underline{\text { SD }}$ & Mean & $\underline{\text { SD }}$ & Mean & $\underline{\text { SD }}$ & & \\
\hline Australia & 9.61 & $(0.59)$ & 11.40 & $(0.43)$ & 13.40 & $(0.18)$ & - & - & 3.79 & $(<0.01)$ \\
\hline Canada & 12.30 & $(0.39)$ & 13.79 & $(0.21)$ & 14.29 & $(0.17)$ & - & - & 1.99 & $(<0.01)$ \\
\hline Finland & 14.50 & $(0.28)$ & 15.43 & $(0.25)$ & 16.06 & $(0.37)$ & - & - & 1.56 & $(<0.01)$ \\
\hline France & 11.48 & $(0.27)$ & - & - & 12.62 & $(0.19)$ & - & - & 1.14 & $(<0.01)$ \\
\hline The Netherlands & 10.39 & $(0.42)$ & 12.95 & $(0.19)$ & 13.32 & $(0.18)$ & 13.33 & $(0.18)$ & 2.94 & $(<0.01)$ \\
\hline Norway & 11.47 & $(0.24)$ & 12.28 & $(0.24)$ & 14.38 & $(0.24)$ & 16.75 & $(0.38)$ & 5.28 & $(<0.01)$ \\
\hline The United Kingdom & 7.65 & $(0.20)$ & 13.69 & $(0.23)$ & 10.83 & $(0.70)$ & 16.15 & $(0.25)$ & 8.50 & $(<0.01)$ \\
\hline
\end{tabular}

Standard deviations in parenthesis. The sample is restricted to include non-retired/non-student individuals between the ages of 21 and 65 (inclusive), see Appendix Table A1 for a description of the surveys included. Housework 1, Housework 2, Housework 3 and Housework 4 are measured in hours per week. Demographic weighting proposed by Katz and Murphy (1992) and used by Aguiar and Hurst (2007) are used to ensure a constant representation of types of individuals and days of the week. $T_{\mathrm{i}}$ is Decade 2000's for the Netherlands, Norway and the United Kingdom, and Decade 1990's for Australia, Canada, Finland and France. 
Table C2. Trends in different definitions of non-market work (women)

\begin{tabular}{|c|c|c|c|c|c|c|c|c|c|c|}
\hline $\begin{array}{l}\text { Time-use category } \\
\text { (hours per week) }\end{array}$ & \multicolumn{2}{|c|}{ DECADE 70's } & \multicolumn{2}{|c|}{ DECADE 80's } & \multicolumn{2}{|c|}{ DECADE 90's } & \multicolumn{2}{|c|}{ DECADE 00's } & \multirow[t]{2}{*}{ Diff. } & \multirow[t]{2}{*}{ P-Value } \\
\hline \multicolumn{9}{|c|}{ Panel A: Core Market Work } & & \\
\hline & $\underline{\text { Mean }}$ & $\underline{\mathbf{S D}}$ & $\underline{\text { Mean }}$ & $\underline{\mathbf{S D}}$ & $\underline{\text { Mean }}$ & $\underline{\mathbf{S D}}$ & $\underline{\text { Mean }}$ & $\underline{\text { SD }}$ & & \\
\hline Australia & 29.38 & $(0.66)$ & 24.36 & $(0.53)$ & 23.00 & $(0.18)$ & - & - & -6.38 & $(<0.01)$ \\
\hline Canada & 26.30 & $(0.42)$ & 19.48 & $(0.20)$ & 19.35 & $(0.15)$ & - & - & -6.95 & $(<0.01)$ \\
\hline Finland & 24.38 & $(0.29)$ & 21.48 & $(0.25)$ & 20.24 & $(0.32)$ & - & - & -4.14 & $(<0.01)$ \\
\hline France & 28.01 & $(0.33)$ & - & - & 23.45 & $(0.18)$ & - & - & -4.56 & $(<0.01)$ \\
\hline The Netherlands & 28.82 & $(0.31)$ & 26.85 & $(0.16)$ & 22.22 & $(0.15)$ & 20.36 & $(0.15)$ & -8.46 & $(<0.01)$ \\
\hline Norway & 33.45 & $(0.27)$ & 25.26 & $(0.23)$ & 20.48 & $(0.22)$ & 17.83 & $(0.27)$ & -15.61 & $(<0.01)$ \\
\hline The United Kingdom & 25.03 & $(0.26)$ & 24.34 & $(0.21)$ & 19.44 & $(0.61)$ & 21.67 & $(0.22)$ & -3.36 & $(<0.01)$ \\
\hline \multicolumn{11}{|c|}{ Panel B: Core Market Work + Shopping } \\
\hline & $\underline{\text { Mean }}$ & $\underline{\text { SD }}$ & $\underline{\text { Mean }}$ & $\underline{\mathbf{S D}}$ & $\underline{\text { Mean }}$ & $\underline{\text { SD }}$ & $\underline{\text { Mean }}$ & $\underline{\text { SD }}$ & & \\
\hline Australia & 29.93 & $(0.65)$ & 26.15 & $(0.55)$ & 23.96 & $(0.18)$ & - & - & -5.97 & $(<0.01)$ \\
\hline Canada & 27.84 & $(0.42)$ & 22.12 & $(0.19)$ & 20.68 & $(0.15)$ & - & - & -7.16 & $(<0.01)$ \\
\hline Finland & 23.55 & $(0.25)$ & 20.82 & $(0.22)$ & 19.81 & $(0.29)$ & - & - & -3.74 & $(<0.01)$ \\
\hline France & 30.20 & $(0.34)$ & - & - & 26.64 & $(0.20)$ & - & - & -3.56 & $(<0.01)$ \\
\hline The Netherlands & 28.32 & $(0.29)$ & 26.68 & $(0.15)$ & 22.66 & $(0.14)$ & 19.91 & $(0.14)$ & -8.41 & $(<0.01)$ \\
\hline Norway & 34.79 & $(0.27)$ & 26.29 & $(0.23)$ & 19.45 & $(0.19)$ & 19.68 & $(0.28)$ & -15.11 & $(<0.01)$ \\
\hline The United Kingdom & 27.66 & $(0.26)$ & 25.94 & $(0.20)$ & 23.65 & $(0.66)$ & 22.55 & $(0.21)$ & -5.11 & $(<0.01)$ \\
\hline \multicolumn{11}{|c|}{ Panel C: Core Market Work + Shopping + Odd jobs } \\
\hline & Mean & $\underline{\text { SD }}$ & Mean & $\underline{\text { SD }}$ & Mean & $\underline{\text { SD }}$ & Mean & $\underline{\text { SD }}$ & & \\
\hline Australia & 32.86 & $(0.70)$ & 28.21 & $(0.57)$ & 27.07 & $(0.19)$ & - & - & -5.79 & $(<0.01)$ \\
\hline Canada & 29.77 & $(0.44)$ & 24.06 & $(0.21)$ & 23.16 & $(0.17)$ & - & - & -6.61 & $(<0.01)$ \\
\hline Finland & 27.33 & $(0.29)$ & 24.50 & $(0.26)$ & 23.69 & $(0.33)$ & - & - & -3.64 & $(<0.01)$ \\
\hline France & 31.67 & $(0.35)$ & - & - & 27.87 & $(0.20)$ & - & - & -3.80 & $(<0.01)$ \\
\hline The Netherlands & 33.19 & $(0.33)$ & 31.10 & $(0.17)$ & 26.38 & $(0.16)$ & 24.59 & $(0.16)$ & -8.60 & $(<0.01)$ \\
\hline Norway & 35.73 & $(0.27)$ & 28.14 & $(0.24)$ & 23.36 & $(0.23)$ & 20.63 & $(0.29)$ & -15.10 & $(<0.01)$ \\
\hline The United Kingdom & 29.23 & $(0.28)$ & 28.90 & $(0.22)$ & 24.78 & $(0.70)$ & 26.02 & $(0.24)$ & -3.22 & $(<0.01)$ \\
\hline \multicolumn{11}{|c|}{ Panel D: Core Market Work + Shopping + Odd jobs + Domestic travel (Unpaid Work) } \\
\hline & Mean & $\underline{\text { SD }}$ & $\underline{\text { Mean }}$ & $\underline{\text { SD }}$ & Mean & $\underline{\text { SD }}$ & $\underline{\text { Mean }}$ & $\underline{\text { SD }}$ & & \\
\hline Australia & 35.26 & $(0.73)$ & 31.78 & $(0.62)$ & 30.84 & $(0.20)$ & - & - & -4.42 & $(<0.01)$ \\
\hline Canada & 32.83 & $(0.46)$ & 27.45 & $(0.22)$ & 26.11 & $(0.18)$ & - & - & -6.71 & $(<0.01)$ \\
\hline Finland & 28.92 & $(0.30)$ & 26.99 & $(0.27)$ & 26.10 & $(0.35)$ & - & - & -2.82 & $(<0.01)$ \\
\hline France & 34.98 & $(0.37)$ & - & - & 30.98 & $(0.22)$ & - & - & -4.00 & $(<0.01)$ \\
\hline The Netherlands & 35.65 & $(0.33)$ & 34.31 & $(0.18)$ & 30.19 & $(0.18)$ & 28.25 & $(0.18)$ & -7.40 & $(<0.01)$ \\
\hline Norway & 37.45 & $(0.28)$ & 29.43 & $(0.25)$ & 25.60 & $(0.25)$ & 24.15 & $(0.36)$ & -13.30 & $(<0.01)$ \\
\hline The United Kingdom & 30.75 & $(0.29)$ & 31.40 & $(0.23)$ & 24.78 & $(0.70)$ & 29.19 & $(0.26)$ & -1.56 & $(<0.01)$ \\
\hline
\end{tabular}


Leisure Measure 1: It includes the time devoted to gardening/pet care, free time travel, excursions, active sports participation, passive sports participation, walking, cinema or theatre, dances or parties, social clubs, pubs, restaurants, visit friends at home, listen to radio, watch television or video, listen to records, tapes or cds, read books, papers or magazines, relax, conversation, entertain friends at home, knit, sew and "other leisure".

Leisure Measure 3: It includes the time devoted to gardening/pet care, free time travel, excursions, active sports participation, passive sports participation, walking, cinema or theatre, dances or parties, social clubs, pubs, restaurants, visit friends at home, listen to radio, watch television or video, listen to records, tapes or cds, read books, papers or magazines, relax, conversation, entertain friends at home, knit, sew, "other leisure", dress and personal care, consume personal services, meals and snacks, sleep, and child care.

Leisure Measure 4: It is calculated as the residual of the time devoted to market and nonmarket work. The difference between Leisure Measure 3 and Leisure Measure 4 includes time spent in civic duties, and religious activities.

Table C3. Trends in Leisure Measure 1 (men and women)

\begin{tabular}{|c|c|c|c|c|c|c|c|c|c|c|}
\hline $\begin{array}{l}\text { Time-use category } \\
\text { (hours per week) }\end{array}$ & \multicolumn{2}{|c|}{ DECADE 70's } & \multicolumn{2}{|c|}{ DECADE 80's } & \multicolumn{2}{|c|}{ DECADE 90's } & \multicolumn{2}{|c|}{ DECADE 00's } & \multirow[t]{2}{*}{ Diff. } & \multirow[t]{2}{*}{ P-Value } \\
\hline \multicolumn{9}{|c|}{$\begin{array}{l}\text { Panel A: Men } \\
\end{array}$} & & \\
\hline & $\underline{\text { Mean }}$ & $\underline{\text { SD }}$ & $\underline{\text { Mean }}$ & $\underline{\text { SD }}$ & Mean & $\underline{\text { SD }}$ & Mean & $\underline{\text { SD }}$ & & \\
\hline Australia & 33.33 & $(1.07)$ & 32.97 & $(0.75)$ & 35.86 & $(0.29)$ & - & - & 2.53 & 0.02 \\
\hline Canada & 33.41 & $(0.58)$ & 36.44 & $(0.31)$ & 38.24 & $(0.27)$ & - & - & 4.83 & $(<0.01)$ \\
\hline Finland & 37.92 & $(0.41)$ & 39.27 & $(0.40)$ & 44.25 & $(0.56)$ & - & - & 6.33 & $(<0.01)$ \\
\hline France & 33.33 & $(0.52)$ & - & - & 30.99 & $(0.28)$ & - & - & -2.34 & $(<0.01)$ \\
\hline The Netherlands & 42.12 & $(0.56)$ & 41.78 & $(0.24)$ & 39.18 & $(0.22)$ & 35.61 & $(0.28)$ & -6.52 & $(<0.01)$ \\
\hline Norway & 34.85 & $(0.36)$ & 38.69 & $(0.37)$ & 39.95 & $(0.39)$ & 38.05 & $(0.50)$ & 3.20 & $(<0.01)$ \\
\hline The United Kingdom & 40.17 & $(0.37)$ & 43.58 & $(0.37)$ & 43.69 & $(1.15)$ & 39.73 & $(0.36)$ & -0.44 & $(0.39)$ \\
\hline \multicolumn{11}{|c|}{ Panel B: Women } \\
\hline & Mean & $\underline{\text { SD }}$ & $\underline{\text { Mean }}$ & $\underline{\text { SD }}$ & Mean & $\underline{\text { SD }}$ & Mean & $\underline{\text { SD }}$ & & \\
\hline Australia & 34.10 & $(0.85)$ & 34.28 & $(0.65)$ & 35.72 & $(0.24)$ & - & - & 1.62 & $(0.07)$ \\
\hline Canada & 31.79 & $(0.41)$ & 34.15 & $(0.24)$ & 34.30 & $(0.21)$ & - & - & 2.50 & $(<0.01)$ \\
\hline Finland & 34.32 & $(0.34)$ & 36.72 & $(0.34)$ & 39.07 & $(0.44)$ & - & - & 4.75 & $(<0.01)$ \\
\hline France & 27.22 & $(0.38)$ & - & - & 25.98 & $(0.21)$ & - & - & -1.24 & $(<0.01)$ \\
\hline The Netherlands & 42.63 & $(0.33)$ & 41.83 & $(0.17)$ & 40.49 & $(0.18)$ & 37.17 & $(0.20)$ & -5.46 & $(<0.01)$ \\
\hline Norway & 32.83 & $(0.28)$ & 38.72 & $(0.29)$ & 38.73 & $(0.31)$ & 37.39 & $(0.43)$ & 4.56 & $(<0.01)$ \\
\hline The United Kingdom & 40.51 & $(0.32)$ & 40.27 & $(0.25)$ & 38.00 & $(0.86)$ & 35.98 & $(0.28)$ & -4.53 & $(<0.01)$ \\
\hline
\end{tabular}

Standard deviations in parenthesis. The sample is restricted to include non-retired/non-student individuals between the ages of 21 and 65 (inclusive), see Appendix Table A1 for a description of the surveys included. Leisure Measure 1 is measured in hours per week. Demographic weighting proposed by Katz and Murphy (1992) and used by Aguiar and Hurst (2007) are used to ensure a constant representation of types of individuals and days of the week. $\mathrm{T}_{\mathrm{i}}$ is Decade 2000's for the Netherlands, Norway and the United Kingdom, and Decade 1990's for Australia, Canada, Finland and France. 
Table C4. Trends in Leisure Measure 3 (men and women)

\begin{tabular}{|c|c|c|c|c|c|c|c|c|c|c|}
\hline $\begin{array}{l}\text { Time-use category } \\
\text { (hours per week) }\end{array}$ & \multicolumn{2}{|c|}{ DECADE 70's } & \multicolumn{2}{|c|}{ DECADE 80's } & \multicolumn{2}{|c|}{ DECADE 90's } & \multicolumn{2}{|c|}{ DECADE 00's } & \multirow[t]{2}{*}{ Diff. } & \multirow[t]{2}{*}{ P-Value } \\
\hline \multicolumn{9}{|c|}{ Panel A: Men } & & \\
\hline & Mean & $\underline{\text { SD }}$ & Mean & $\underline{\text { SD }}$ & Mean & $\underline{\text { SD }}$ & Mean & $\underline{\text { SD }}$ & & \\
\hline Canada & 107.09 & $(0.77)$ & 108.58 & $(0.37)$ & 108.50 & $(0.32)$ & - & - & 1.41 & $(0.09)$ \\
\hline Finland & 112.62 & $(0.50)$ & 112.22 & $(0.49)$ & 119.75 & $(0.68)$ & - & - & 7.13 & $(<0.01)$ \\
\hline France & 115.54 & $(0.66)$ & - & - & 112.02 & $(0.38)$ & - & - & -3.51 & $(<0.01)$ \\
\hline Norway & 110.12 & $(0.46)$ & 112.55 & $(0.49)$ & 110.92 & $(0.50)$ & 108.80 & $(0.69)$ & -1.32 & $(0.11)$ \\
\hline The United Kingdom & 112.26 & $(0.44)$ & 115.19 & $(0.45)$ & 118.82 & $(1.38)$ & 116.65 & $(0.46)$ & 4.39 & $(<0.01)$ \\
\hline \multicolumn{11}{|c|}{ Panel B: Women } \\
\hline & Mean & $\underline{\text { SD }}$ & Mean & $\underline{\text { SD }}$ & Mean & $\underline{\text { SD }}$ & Mean & $\underline{\text { SD }}$ & & \\
\hline Australia & 116.86 & $(0.93)$ & 117.25 & $(0.75)$ & 117.15 & $(0.27)$ & - & & 0.28 & $(0.77)$ \\
\hline Norway & 115.34 & $(0.34)$ & 117.77 & $(0.37)$ & 117.28 & $(0.39)$ & 116.63 & $(0.59)$ & 1.29 & $(0.06)$ \\
\hline The United Kingdom & 117.88 & $(0.36)$ & 120.16 & $(0.29)$ & 119.95 & $(0.99)$ & 117.97 & $(0.34)$ & 0.08 & $(0.86)$ \\
\hline
\end{tabular}

Standard deviations in parenthesis. The sample is restricted to include non-retired/non-student individuals between the ages of 21 and 65 (inclusive), see Appendix Table A1 for a description of the surveys included. Leisure Measure 3 is measured in hours per week. Demographic weighting proposed by Katz and Murphy (1992) and used by Aguiar and Hurst (2007) are used to ensure a constant representation of types of individuals and days of the week. $\mathrm{T}_{\mathrm{i}}$ is Decade 2000's for the Netherlands, Norway and the United Kingdom, and Decade 1990's for Australia, Canada, Finland and France.

Table C5. Trends in Leisure Measure 4 (men and women)

\begin{tabular}{|c|c|c|c|c|c|c|c|c|c|c|}
\hline $\begin{array}{l}\begin{array}{l}\text { Time-use category } \\
\text { (hours per week) }\end{array} \\
\end{array}$ & \multicolumn{2}{|c|}{ DECADE 70's } & DECA & 80 's & \multicolumn{2}{|c|}{ DECADE 90's } & \multicolumn{2}{|c|}{ DECADE 00's } & Diff. & P-Value \\
\hline & Mean & $\underline{\text { SD }}$ & Mean & $\underline{\text { SD }}$ & Mean & $\underline{\text { SD }}$ & Mean & $\underline{\text { SD }}$ & & \\
\hline Canada & 106.63 & $(0.78)$ & 107.62 & $(0.37)$ & 106.83 & $(0.32)$ & - & - & 0.20 & $(0.82)$ \\
\hline Finland & 112.95 & $(0.50)$ & 112.16 & $(0.50)$ & 118.75 & $(0.68)$ & - & - & 5.80 & $(<0.01)$ \\
\hline France & 114.63 & $(0.65)$ & - & - & 111.46 & $(0.38)$ & - & - & -3.17 & $(<0.01)$ \\
\hline The Netherlands & 116.04 & $(0.74)$ & 114.61 & $(0.30)$ & 110.09 & $(0.27)$ & 108.52 & $(0.35)$ & -7.52 & $(<0.01)$ \\
\hline \multicolumn{11}{|c|}{ Panel B: Women } \\
\hline & Mean & $\underline{\mathrm{SD}}$ & Mean & $\underline{\text { SD }}$ & Mean & $\underline{\text { SD }}$ & Mean & $\underline{\text { SD }}$ & & \\
\hline Australia & $\overline{112.26}$ & $(\overline{0.98)}$ & $\overline{110.02}$ & $(\overline{0.77})$ & $\overline{111.31}$ & $(\overline{0.28})$ & - & & -0.95 & $(0.35)$ \\
\hline Canada & 108.63 & $(0.56)$ & 108.88 & $(0.29)$ & 106.63 & $(0.25)$ & - & & -2.00 & $(<0.01)$ \\
\hline Finland & 108.37 & $(0.42)$ & 110.23 & $(0.42)$ & 114.21 & $(0.54)$ & - & & 5.84 & $(<0.01)$ \\
\hline France & 107.22 & $(0.48)$ & & & 108.27 & $(0.27)$ & - & & 1.05 & $(0.06)$ \\
\hline
\end{tabular}

Standard deviations in parenthesis. The sample is restricted to include non-retired/non-student individuals between the ages of 21 and 65 (inclusive), see Appendix Table A1 for a description of the surveys included. Leisure Measure 4 is measured in hours per week. Demographic weighting proposed by Katz and Murphy (1992) and used by Aguiar and Hurst (2007) are used to ensure a constant representation of types of individuals and days of the week. $\mathrm{T}_{\mathrm{i}}$ is Decade 2000's for the Netherlands, Norway and the United Kingdom, and Decade 1990's for Australia, Canada, Finland and France. 
Table C6. Trends in aggregate personal care (men and women)

\begin{tabular}{|c|c|c|c|c|c|c|c|c|c|c|}
\hline $\begin{array}{l}\text { Aggregate personal care } \\
\text { (hours per week) }\end{array}$ & \multicolumn{2}{|c|}{ DECADE 70's } & \multicolumn{2}{|c|}{ DECADE 80's } & \multicolumn{2}{|c|}{ DECADE 90's } & \multicolumn{2}{|c|}{ DECADE 00's } & \multirow[t]{2}{*}{ Diff. } & \multirow[t]{2}{*}{ P-Value } \\
\hline \multicolumn{9}{|c|}{ Panel A: Men } & & \\
\hline & Mean & SD & Mean & SD & Mean & SD & Mean & SD & & \\
\hline Australia & 69.74 & $(0.61)$ & 70.53 & $(0.47)$ & 70.28 & $(0.18)$ & - & - & 0.53 & $(0.40)$ \\
\hline Canada & 70.43 & $(0.43)$ & 68.18 & $(0.21)$ & 65.60 & $(0.15)$ & - & - & -4.83 & $<0.01$ \\
\hline Finland & 72.76 & $(0.23)$ & 71.01 & $(0.23)$ & 71.06 & $(0.35)$ & - & - & -1.70 & $<0.01$ \\
\hline France & 78.37 & $(0.35)$ & & & 75.98 & $(0.21)$ & - & - & -2.38 & $<0.01$ \\
\hline The Netherlands & 71.58 & $(0.48)$ & 70.49 & $(0.17)$ & 68.76 & $(0.16)$ & 70.04 & $(0.18)$ & -1.54 & $<0.01$ \\
\hline Norway & 75.76 & $(0.19)$ & 71.85 & $(0.19)$ & 69.97 & $(0.19)$ & 69.32 & $(0.30)$ & -6.44 & $<0.01$ \\
\hline The United Kingdom & 71.22 & $(0.23)$ & 69.31 & $(0.21)$ & 67.41 & $(0.72)$ & 70.94 & $(0.24)$ & -0.28 & $(0.39)$ \\
\hline \multicolumn{11}{|c|}{ Panel B: Women } \\
\hline & Mean & SD & Mean & SD & Mean & SD & Mean & SD & & \\
\hline Australia & 76.51 & $(0.56)$ & 74.81 & $(0.43)$ & 73.20 & $(0.16)$ & - & - & -3.31 & $<0.01$ \\
\hline Canada & 74.56 & $(0.35)$ & 71.84 & $(0.17)$ & 69.38 & $(0.13)$ & - & - & -5.18 & $<0.01$ \\
\hline Finland & 72.71 & $(0.22)$ & 72.03 & $(0.21)$ & 72.91 & $(0.30)$ & - & - & 0.20 & $(0.59)$ \\
\hline France & 78.74 & $(0.28)$ & & & 78.98 & $(0.17)$ & & & 0.23 & $(0.48)$ \\
\hline The Netherlands & 75.87 & $(0.29)$ & 74.19 & $(0.13)$ & 73.95 & $(0.13)$ & 75.68 & $(0.15)$ & -0.19 & $(0.55)$ \\
\hline Norway & 75.76 & $(0.19)$ & 71.85 & $(0.19)$ & 69.97 & $(0.19)$ & 69.32 & $(0.30)$ & -6.44 & $<0.01$ \\
\hline The United Kingdom & 74.56 & $(0.21)$ & 74.00 & $(0.17)$ & 71.26 & $(0.59)$ & 74.31 & $(0.21)$ & -0.25 & $(0.39)$ \\
\hline
\end{tabular}




\section{APPENDIX D: Results for Working Individuals}

Table D1. Trends in Leisure inequality, working individuals (men and women)

\begin{tabular}{|c|c|c|c|c|}
\hline Leisure (hours per week) & $\begin{array}{c}\text { DECADE } \\
1970 \mathrm{~s} \\
\end{array}$ & $\begin{array}{c}\text { DECADE } \\
1980 \mathrm{~s}\end{array}$ & $\begin{array}{c}\text { DECADE } \\
1990 \mathrm{~s}\end{array}$ & $\begin{array}{c}\text { DECADE } \\
2000 \mathrm{~s}\end{array}$ \\
\hline \multicolumn{5}{|c|}{ Panel A: Gini Index } \\
\hline Australia & 12.920 & 14.000 & 14.150 & - \\
\hline Canada & 13.010 & 14.310 & 15.500 & - \\
\hline Finland & 13.050 & 13.800 & 13.760 & - \\
\hline France & 13.330 & - & 13.550 & - \\
\hline The Netherlands & 6.510 & 6.950 & 7.520 & 13.670 \\
\hline Norway & 13.170 & 13.210 & 13.710 & 14.420 \\
\hline The United Kingdom & 11.700 & 12.500 & 14.020 & 13.600 \\
\hline \multicolumn{5}{|c|}{ Panel B: 90th/10th } \\
\hline Australia & 1.872 & 1.915 & 1.938 & - \\
\hline Canada & 1.939 & 1.976 & 2.117 & - \\
\hline Finland & 1.826 & 1.882 & 1.913 & - \\
\hline France & 1.919 & - & 1.881 & - \\
\hline The Netherlands & 1.313 & 1.305 & 1.325 & 1.921 \\
\hline Norway & 1.977 & 1.911 & 1.867 & 1.938 \\
\hline The United Kingdom & 1.720 & 1.809 & 1.956 & 1.912 \\
\hline
\end{tabular}

The sample is restricted to include non-retired/non-student individuals between the ages of 21 and 65 (inclusive), see Appendix Table A1 for a description of the surveys included. Leisure is measured in hours per week, see Table Appendix A2 for a list of activities included in our definition of leisure. Demographic weighting proposed by Katz and Murphy (1992) and used by Aguiar and Hurst (2007) are used to ensure a constant representation of types of individuals and days of the week. Gini index is multiplied by 100 . 
Table D2. Inequality in Leisure over the period, low and highly-educated working individuals (men and women)

\begin{tabular}{|c|c|c|c|c|c|c|c|c|c|c|c|}
\hline $\begin{array}{l}\text { Time-use category } \\
\text { (hours per week) }\end{array}$ & & \multicolumn{2}{|c|}{ DECADE 70's } & \multicolumn{2}{|c|}{ DECADE 80's } & \multicolumn{2}{|c|}{ DECADE 90's } & \multicolumn{2}{|c|}{ DECADE 00's } & \multirow[t]{2}{*}{ Diff. } & \multirow[t]{2}{*}{$\begin{array}{c}\text { Cum. } \\
\text { Diff }\end{array}$} \\
\hline \multicolumn{10}{|c|}{ Panel A: Men } & & \\
\hline \multirow{3}{*}{ Australia } & & Mean & $\underline{\text { SD }}$ & Mean & $\underline{\text { SD }}$ & Mean & $\underline{\text { SD }}$ & Mean & $\underline{\text { SD }}$ & & \\
\hline & Less than high-school & 104.69 & $(2.42)$ & 101.24 & $(1.66)$ & 105.50 & $(0.71)$ & - & - & 0.81 & -0.32 \\
\hline & Some college and college grads & 102.95 & $(0.00)$ & 101.12 & $(0.00)$ & 104.08 & $(0.01)$ & - & - & 1.13 & $(0.89)$ \\
\hline \multirow[t]{2}{*}{ Canada } & Less than high-school & 104.27 & $(0.99)$ & 104.18 & $(0.67)$ & 106.03 & $(0.78)$ & - & - & 1.76 & 3.18 \\
\hline & Some college and college grads & 104.28 & $(0.00)$ & 102.56 & $(2.08)$ & 102.86 & $(0.88)$ & - & - & -1.42 & $(0.04)$ \\
\hline \multirow[t]{2}{*}{ Finland } & Less than high-school & 108.24 & $(0.54)$ & 106.79 & $(0.60)$ & 115.99 & $(0.79)$ & - & - & 7.75 & 1.79 \\
\hline & Some college and college grads & 109.37 & $(0.00)$ & 108.96 & $(0.00)$ & 115.33 & $(0.00)$ & - & - & 5.96 & $(0.38)$ \\
\hline \multirow[t]{2}{*}{ France } & Less than high-school & 113.00 & $(0.94)$ & - & - & 109.26 & $(1.14)$ & - & - & -3.74 & 1.11 \\
\hline & Some college and college grads & 112.11 & $(0.00)$ & - & - & 107.26 & $(0.00)$ & - & - & -4.85 & $(0.40)$ \\
\hline \multirow[t]{2}{*}{ The Netherlands } & Less than high-school & 114.87 & $(0.83)$ & 112.15 & $(0.37)$ & 110.08 & $(0.48)$ & 109.45 & $(0.87)$ & -5.42 & 1.95 \\
\hline & Some college and college grads & 113.16 & $(0.00)$ & 109.88 & $(0.32)$ & 106.83 & $(0.30)$ & 105.79 & $(0.57)$ & -7.37 & $(0.13)$ \\
\hline \multirow[t]{2}{*}{ Norway } & Less than high-school & - & - & 111.18 & $(0.64)$ & 107.72 & $(1.44)$ & 103.29 & $(2.43)$ & -7.89 & -2.58 \\
\hline & Some college and college grads & - & - & 109.89 & $(0.00)$ & 108.19 & $(0.00)$ & 104.58 & $(0.00)$ & -5.31 & $(0.33)$ \\
\hline \multirow[t]{2}{*}{ The United Kingdom } & Less than high-school & 111.86 & $(0.52)$ & 108.66 & $(0.69)$ & 110.32 & $(6.89)$ & 110.91 & $(0.85)$ & -0.95 & -0.49 \\
\hline & Some college and college grads & 113.55 & $(0.00)$ & 108.69 & $(1.09)$ & 110.37 & $(0.00)$ & 113.09 & $(0.00)$ & -0.46 & $(0.72)$ \\
\hline \multicolumn{12}{|c|}{ Panel B: Women } \\
\hline \multirow{3}{*}{ Australia } & & Mean & $\underline{\text { SD }}$ & Mean & $\underline{\text { SD }}$ & Mean & $\underline{\text { SD }}$ & Mean & $\underline{\text { SD }}$ & & \\
\hline & Less than high-school & 103.72 & $(2.21)$ & 106.65 & $(1.70)$ & 106.24 & $(0.58)$ & - & - & 2.52 & 4.01 \\
\hline & Some college and college grads & 104.96 & $(2.85)$ & 102.61 & $(1.36)$ & 103.47 & $(0.62)$ & - & - & -1.49 & $(0.28)$ \\
\hline \multirow[t]{2}{*}{ Canada } & Less than high-school & 100.25 & $(1.24)$ & 100.73 & $(0.82)$ & 100.62 & $(0.85)$ & - & - & 0.37 & 2.00 \\
\hline & Some college and college grads & 102.59 & $(1.62)$ & 101.48 & $(0.54)$ & 100.96 & $(0.38)$ & - & - & -1.63 & $(0.53)$ \\
\hline \multirow[t]{2}{*}{ Finland } & Less than high-school & 102.69 & $(0.53)$ & 105.36 & $(0.61)$ & 112.58 & $(0.72)$ & - & - & 9.89 & 1.85 \\
\hline & Some college and college grads & 105.70 & $(0.99)$ & 106.91 & $(1.07)$ & 113.74 & $(1.35)$ & - & - & 8.04 & $(0.32)$ \\
\hline \multirow[t]{2}{*}{ France } & Less than high-school & 101.21 & $(0.92)$ & - & - & 102.87 & $(1.13)$ & - & - & 1.66 & 5.34 \\
\hline & Some college and college grads & 106.04 & $(1.95)$ & - & - & 102.36 & $(0.46)$ & - & - & -3.68 & $(0.07)$ \\
\hline \multirow[t]{2}{*}{ The Netherlands } & Less than high-school & 114.42 & (1.03) & 114.25 & $(0.37)$ & 113.48 & $(0.47)$ & 113.66 & $(0.77)$ & -0.76 & 5.77 \\
\hline & Some college and college grads & 115.90 & $(1.50)$ & 110.45 & $(0.77)$ & 111.10 & $(0.47)$ & 109.37 & $(0.49)$ & -6.53 & $(0.01)$ \\
\hline \multirow[t]{2}{*}{ Norway } & Less than high-school & - & - & 108.26 & $(0.65)$ & 108.54 & $(1.18)$ & 111.14 & $(2.18)$ & 2.88 & 4.96 \\
\hline & Some college and college grads & - & - & 107.68 & $(1.16)$ & 105.41 & $(0.78)$ & 105.60 & $(1.05)$ & -2.08 & $(0.06)$ \\
\hline \multirow{2}{*}{ The United Kingdom } & Less than high-school & 109.48 & $(0.58)$ & 109.24 & $(0.55)$ & 110.30 & $(8.15)$ & 114.34 & $(0.71)$ & 4.86 & 2.05 \\
\hline & Some college and college grads & 108.54 & $(1.41)$ & 104.55 & $(0.79)$ & 111.79 & $(2.56)$ & 111.35 & $(0.72)$ & 2.81 & $(0.92)$ \\
\hline
\end{tabular}

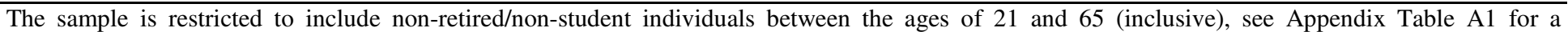

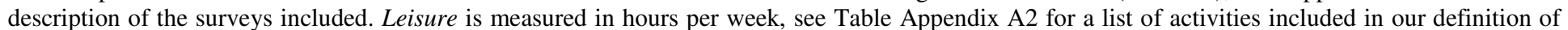

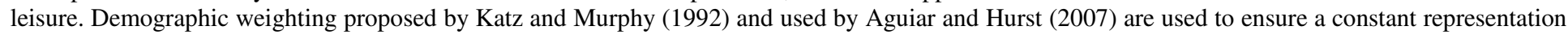

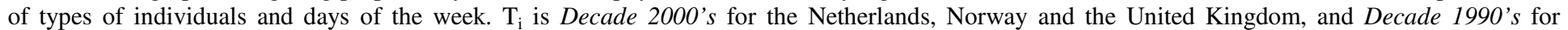

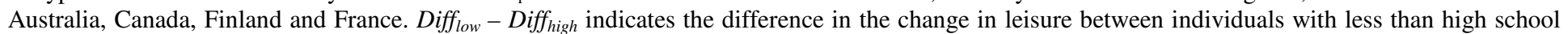

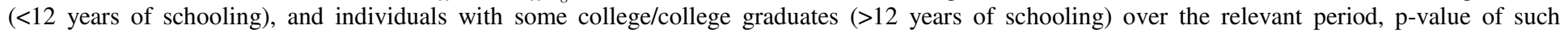
difference in parentheses. 


\section{APPENDIX E: Analysis Including Retired Individuals}

Table E1. Life expectancy at birth

\begin{tabular}{lcccc}
\hline Life Expectancy at birth & DECADE 70's & DECADE 80's & DECADE 90's & DECADE 00's \\
\hline Australia & 72.3 & 76.5 & 78.0 & 80.6 \\
Canada & 73.3 & 77.3 & 78.1 & 79.8 \\
Finland & 71.4 & 75.0 & 76.4 & 79.0 \\
France & 72.9 & 76.5 & 77.8 & 80.1 \\
Netherlands & 74.5 & 76.8 & 77.4 & 79.3 \\
Norway & 75.0 & 76.7 & 77.8 & 80.0 \\
United Kingdom & 71.9 & 75.3 & 76.6 & 79.0 \\
\hline \hline
\end{tabular}

Source: OCDE (2011a). Life expectancy defined for the total population.

Table E2. Trends in average effective age of retirement

\begin{tabular}{|c|c|c|c|c|}
\hline Average effective age of retirement & DECADE 70's & DECADE 80's & DECADE 90's & DECADE 00's \\
\hline \multicolumn{5}{|c|}{ Panel A: Men } \\
\hline Australia & 65.47 & 64.06 & 62.55 & 63.22 \\
\hline Canada & 65.88 & 63.48 & 60.58 & 60.51 \\
\hline Finland & 65.41 & 61.48 & 59.59 & 58.73 \\
\hline France & 64.61 & 61.23 & 60.59 & 61.07 \\
\hline The Netherlands & 67.53 & 65.99 & 64.20 & 63.76 \\
\hline Norway & 67.08 & 63.65 & 62.33 & 63.28 \\
\hline The United Kingdom & 67.08 & 65.76 & 64.59 & 64.73 \\
\hline \multicolumn{5}{|c|}{ Panel B: Women } \\
\hline Australia & 62.78 & 59.43 & 59.71 & 61.29 \\
\hline Canada & 65.07 & 62.98 & 60.78 & 61.63 \\
\hline Finland & 62.33 & 61.88 & 59.97 & 60.41 \\
\hline France & 65.41 & 61.89 & 59.88 & 59.09 \\
\hline The Netherlands & 65.40 & 61.51 & 59.23 & 59.98 \\
\hline Norway & 67.26 & 64.51 & 62.71 & 62.85 \\
\hline The United Kingdom & 64.53 & 61.37 & 60.60 & 61.48 \\
\hline
\end{tabular}

Source: OCDE (2011b). OECD estimates based on the results of national labour force surveys, the European Union Labour Force Survey and, for earlier years in some countries, national censuses. The average effective age of retirement is calculated as a weighted average of (net) withdrawals from the labour market at different ages over a 5-year period for workers initially aged 40 and over. In order to abstract from compositional effects in the age structure of the population, labour force withdrawals are estimated based on changes in labour force participation rates rather than labour force levels. These changes are calculated for each (synthetic) cohort divided into 5-year age groups. 
Table E3. Trends in leisure, paid work, unpaid work, and child care (men), including retired people

\begin{tabular}{|c|c|c|c|c|c|c|c|c|c|c|}
\hline $\begin{array}{l}\text { Time-use category } \\
\text { (hours per week) }\end{array}$ & \multicolumn{2}{|c|}{ DECADE 70's } & \multicolumn{2}{|c|}{ DECADE 80's } & \multicolumn{2}{|c|}{ DECADE 90's } & \multicolumn{2}{|c|}{ DECADE 00's } & \multirow[t]{2}{*}{ Diff. } & \multirow[t]{2}{*}{ P-Value } \\
\hline \multicolumn{9}{|c|}{ Panel A: Leisure } & & \\
\hline & Mean & $\underline{\text { SD }}$ & Mean & $\underline{\text { SD }}$ & Mean & $\underline{\text { SD }}$ & Mean & $\underline{\text { SD }}$ & & \\
\hline Australia & 105.45 & $(1.23)$ & 107.66 & $(0.87)$ & 112.22 & $(0.32)$ & - & - & 6.77 & $(<0.01)$ \\
\hline Canada & 106.13 & $(0.75)$ & 111.16 & $(0.35)$ & 110.50 & $(0.30)$ & - & - & 4.37 & $(<0.01)$ \\
\hline Finland & 112.62 & $(0.50)$ & 114.31 & $(0.47)$ & 122.50 & $(0.60)$ & - & - & 9.89 & $(<0.01)$ \\
\hline France & 114.16 & $(0.65)$ & - & - & 114.05 & $(0.35)$ & - & - & -0.11 & $(0.88)$ \\
\hline The Netherlands & 118.74 & $(0.78)$ & 118.96 & $(0.35)$ & 114.71 & $(0.32)$ & 113.99 & -0.31 & -4.75 & $(<0.01)$ \\
\hline Norway & 111.01 & $(0.42)$ & 113.65 & $(0.44)$ & 113.27 & $(0.44)$ & 112.35 & -0.589 & 1.34 & $(0.06)$ \\
\hline The United Kingdom & 117.39 & $(0.45)$ & 118.66 & $(0.43)$ & 125.51 & $(1.24)$ & 120.26 & -0.406 & 2.87 & $(<0.01)$ \\
\hline \multicolumn{11}{|c|}{ Panel B: Paid work } \\
\hline & Mean & $\underline{\text { SD }}$ & Mean & $\underline{\text { SD }}$ & Mean & $\underline{\text { SD }}$ & Mean & $\underline{\text { SD }}$ & & \\
\hline Australia & 50.56 & $(1.43)$ & 45.20 & $(1.04)$ & 37.40 & $(0.37)$ & - & - & -13.16 & $(<0.01)$ \\
\hline Canada & 46.63 & $(0.86)$ & 39.19 & $(0.39)$ & 38.70 & $(0.34)$ & - & - & -7.93 & $(<0.01)$ \\
\hline Finland & 38.08 & $(0.56)$ & 35.17 & $(0.53)$ & 25.41 & $(0.65)$ & - & - & -12.67 & $(<0.01)$ \\
\hline France & 40.39 & $(0.75)$ & - & - & 37.04 & $(0.42)$ & - & - & -3.35 & $(<0.01)$ \\
\hline The Netherlands & 33.30 & $(0.90)$ & 30.85 & $(0.41)$ & 33.93 & $(0.38)$ & 33.18 & -0.362 & -0.12 & $(0.91)$ \\
\hline Norway & 42.49 & $(0.48)$ & 38.03 & $(0.50)$ & 35.41 & $(0.49)$ & 32.79 & -0.676 & -9.71 & $(<0.01)$ \\
\hline The United Kingdom & 39.93 & $(0.52)$ & 31.70 & $(0.50)$ & 27.23 & $(1.27)$ & 26.59 & -0.462 & -13.33 & $(<0.01)$ \\
\hline \multicolumn{11}{|c|}{ Panel C: Unpaid work } \\
\hline & Mean & $\underline{\text { SD }}$ & Mean & $\underline{\text { SD }}$ & Mean & $\underline{\text { SD }}$ & Mean & $\underline{\text { SD }}$ & & \\
\hline Australia & 10.12 & $(0.56)$ & 12.39 & $(0.41)$ & 14.56 & $(0.16)$ & - & - & 4.44 & $(<0.01)$ \\
\hline Canada & 12.47 & $(0.38)$ & 14.55 & $(0.20)$ & 14.97 & $(0.15)$ & - & - & 2.51 & $(<0.01)$ \\
\hline Finland & 14.89 & $(0.28)$ & 16.42 & $(0.25)$ & 17.03 & $(0.33)$ & - & - & 2.14 & $(<0.01)$ \\
\hline France & 11.47 & $(0.27)$ & - & - & 13.55 & $(0.18)$ & - & - & 2.08 & $(<0.01)$ \\
\hline The Netherlands & 12.28 & $(0.48)$ & 14.39 & $(0.19)$ & 15.22 & $(0.18)$ & 16.01 & -0.167 & 3.73 & $(<0.01)$ \\
\hline Norway & 11.96 & $(0.22)$ & 13.14 & $(0.22)$ & 16.01 & $(0.23)$ & 18.54 & -0.333 & 6.58 & $(<0.01)$ \\
\hline The United Kingdom & 9.11 & $(0.21)$ & 15.45 & $(0.23)$ & 11.94 & $(0.59)$ & 18.23 & -0.233 & 9.13 & $(<0.01)$ \\
\hline \multicolumn{11}{|c|}{ Panel D: Child Care } \\
\hline & Mean & $\underline{\text { SD }}$ & Mean & $\underline{\text { SD }}$ & Mean & $\underline{\mathrm{SD}}$ & Mean & $\underline{\text { SD }}$ & & \\
\hline Australia & 1.37 & $(0.18)$ & 1.91 & $(0.14)$ & 2.08 & $(0.06)$ & - & - & 0.71 & $(<0.01)$ \\
\hline Canada & 1.57 & $(0.12)$ & 1.80 & $(0.06)$ & 2.46 & $(0.07)$ & - & - & 0.89 & $(<0.01)$ \\
\hline Finland & 0.97 & $(0.06)$ & 0.96 & $(0.06)$ & 1.62 & $(0.11)$ & - & - & 0.65 & $(<0.01)$ \\
\hline France & 1.44 & $(0.08)$ & - & - & 1.78 & $(0.06)$ & - & - & 0.34 & $(<0.01)$ \\
\hline The Netherlands & 1.76 & $(0.13)$ & 1.78 & $(0.06)$ & 2.24 & $(0.08)$ & 2.15 & -0.065 & 0.38 & $(<0.01)$ \\
\hline Norway & 1.52 & $(0.06)$ & 2.21 & $(0.08)$ & 2.45 & $(0.10)$ & 2.61 & -0.133 & 1.09 & $(<0.01)$ \\
\hline The United Kingdom & 0.53 & $(0.03)$ & 1.40 & $(0.06)$ & 1.91 & $(0.28)$ & 1.54 & -0.065 & 1.01 & $(<0.01)$ \\
\hline
\end{tabular}

Standard deviations in parenthesis. The sample is restricted to include non-student individuals who are 21 years old or older, see Appendix Table A1 for a description of the surveys included. Leisure, paid work, unpaid work and child care are measured in hours per week, see Table Appendix A2 for definitions of time-use categories. Ti is Decade 2000's for the Netherlands, Norway and the United Kingdom, and Decade 1990's for Australia, Canada, Finland and France. 
Table E4. Trends in leisure, paid work, unpaid work, and child care (women), including retired people

\begin{tabular}{|c|c|c|c|c|c|c|c|c|c|c|}
\hline $\begin{array}{l}\text { Time-use category } \\
\text { (hours per week) }\end{array}$ & \multicolumn{2}{|c|}{ DECADE 70's } & \multicolumn{2}{|c|}{ DECADE 80's } & \multicolumn{2}{|c|}{ DECADE 90's } & \multicolumn{2}{|c|}{ DECADE 00's } & \multirow[t]{2}{*}{ Diff. } & \multirow[t]{2}{*}{ P-Value } \\
\hline \multicolumn{9}{|c|}{ Panel A: Leisure } & & \\
\hline & Mean & $\underline{\text { SD }}$ & Mean & $\underline{\text { SD }}$ & Mean & $\underline{\text { SD }}$ & Mean & $\underline{\text { SD }}$ & & \\
\hline Australia & 112.47 & $(0.89)$ & 113.66 & $(0.72)$ & 114.04 & $(0.26)$ & - & - & 1.57 & $(0.09)$ \\
\hline Canada & 107.93 & $(0.54)$ & 112.92 & $(0.27)$ & 112.18 & $(0.23)$ & - & - & 4.25 & $(<0.01)$ \\
\hline Finland & 108.94 & $(0.42)$ & 114.21 & $(0.39)$ & 119.63 & $(0.45)$ & - & - & 10.69 & $(<0.01)$ \\
\hline France & 106.88 & $(0.48)$ & - & - & 111.18 & $(0.25)$ & - & - & 4.31 & $(<0.01)$ \\
\hline The Netherlands & 120.36 & $(0.38)$ & 118.51 & $(0.20)$ & 117.45 & $(0.21)$ & 116.32 & $(0.22)$ & -4.04 & $(<0.01)$ \\
\hline Norway & 111.60 & $(0.32)$ & 114.23 & $(0.33)$ & 114.33 & $(0.34)$ & 114.22 & $(0.48)$ & 2.62 & $(<0.01)$ \\
\hline The United Kingdom & 120.35 & $(0.35)$ & 119.28 & $(0.28)$ & 122.06 & $(0.91)$ & 119.86 & $(0.30)$ & -0.49 & $(0.28)$ \\
\hline \multicolumn{11}{|c|}{ Panel B: Paid work } \\
\hline & Mean & $\underline{\text { SD }}$ & $\underline{\text { Mean }}$ & $\underline{\text { SD }}$ & $\underline{\text { Mean }}$ & $\underline{\text { SD }}$ & $\underline{\text { Mean }}$ & $\underline{\text { SD }}$ & & \\
\hline Australia & 13.10 & $(0.92)$ & 15.23 & $(0.75)$ & 14.71 & $(0.26)$ & - & - & 1.61 & $(0.09)$ \\
\hline Canada & 18.92 & $(0.69)$ & 20.50 & $(0.30)$ & 22.25 & $(0.25)$ & - & - & 3.33 & $(<0.01)$ \\
\hline Finland & 25.72 & $(0.49)$ & 21.67 & $(0.43)$ & 16.04 & $(0.48)$ & - & - & -9.68 & $(<0.01)$ \\
\hline France & 19.84 & $(0.60)$ & - & - & 18.20 & $(0.31)$ & - & - & -1.64 & $(0.02)$ \\
\hline The Netherlands & 5.58 & $(0.34)$ & 8.17 & $(0.19)$ & 12.94 & $(0.22)$ & 15.63 & $(0.23)$ & 10.05 & $(<0.01)$ \\
\hline Norway & 13.24 & $(0.31)$ & 17.03 & $(0.35)$ & 19.54 & $(0.38)$ & 20.08 & $(0.52)$ & 6.85 & $(<0.01)$ \\
\hline The United Kingdom & 13.69 & $(0.35)$ & 11.82 & $(0.26)$ & 13.10 & $(0.79)$ & 12.65 & $(0.28)$ & -1.04 & $(0.02)$ \\
\hline \multicolumn{11}{|c|}{ Panel C: Unpaid work } \\
\hline & $\underline{\text { Mean }}$ & $\underline{\text { SD }}$ & $\underline{\text { Mean }}$ & $\underline{\text { SD }}$ & $\underline{\text { Mean }}$ & $\underline{\text { SD }}$ & $\underline{\text { Mean }}$ & $\underline{\text { SD }}$ & & \\
\hline Australia & 35.70 & $(0.69)$ & 31.20 & $(0.55)$ & 30.78 & $(0.18)$ & - & - & -4.93 & $(<0.01)$ \\
\hline Canada & 32.96 & $(0.46)$ & 27.91 & $(0.20)$ & 26.35 & $(0.16)$ & - & - & -6.61 & $(<0.01)$ \\
\hline Finland & 29.48 & $(0.30)$ & 28.01 & $(0.25)$ & 27.31 & $(0.30)$ & - & - & -2.17 & $(<0.01)$ \\
\hline France & 35.06 & $(0.37)$ & - & - & 31.58 & $(0.19)$ & - & - & -3.47 & $(<0.01)$ \\
\hline The Netherlands & 35.21 & $(0.32)$ & 33.96 & $(0.16)$ & 30.27 & $(0.17)$ & 28.82 & $(0.17)$ & -6.39 & $(<0.01)$ \\
\hline Norway & 37.12 & $(0.25)$ & 30.50 & $(0.24)$ & 27.10 & $(0.22)$ & 25.69 & $(0.30)$ & -11.43 & $(<0.01)$ \\
\hline The United Kingdom & 30.59 & $(0.26)$ & 31.94 & $(0.22)$ & 25.89 & $(0.64)$ & 30.43 & $(0.22)$ & -0.17 & $(0.62)$ \\
\hline \multicolumn{11}{|c|}{ Panel D: Child Care } \\
\hline & Mean & $\underline{\mathrm{SD}}$ & Mean & $\underline{\text { SD }}$ & Mean & $\underline{\mathrm{SD}}$ & Mean & $\underline{\text { SD }}$ & & \\
\hline Australia & 5.39 & $(0.34)$ & 6.95 & $(0.36)$ & 6.36 & $(0.13)$ & - & - & 0.97 & $(<0.01)$ \\
\hline Canada & 6.78 & $(0.23)$ & 5.07 & $(0.10)$ & 5.52 & $(0.10)$ & - & - & -1.25 & $(<0.01)$ \\
\hline Finland & 2.80 & $(0.11)$ & 2.82 & $(0.11)$ & 3.72 & $(0.17)$ & - & - & 0.92 & $(<0.01)$ \\
\hline France & 5.82 & $(0.19)$ & - & - & 5.82 & $(0.11)$ & - & - & 0.00 & $(0.99)$ \\
\hline The Netherlands & 5.22 & $(0.20)$ & 5.60 & $(0.12)$ & 5.58 & $(0.11)$ & 4.99 & $(0.09)$ & -0.24 & $(0.28)$ \\
\hline Norway & 5.27 & $(0.12)$ & 5.37 & $(0.14)$ & 6.13 & $(0.17)$ & 6.72 & $(0.22)$ & 1.45 & $(<0.01)$ \\
\hline The United Kingdom & 1.89 & $(0.07)$ & 4.00 & $(0.10)$ & 4.71 & $(0.37)$ & 3.26 & $(0.09)$ & 1.38 & $(<0.01)$ \\
\hline
\end{tabular}

Standard deviations in parenthesis. The sample is restricted to include non-student individuals who are 21 years old or older, see Appendix Table A1 for a description of the surveys included. Leisure, paid work, unpaid work and child care are measured in hours per week, see Table Appendix A2 for definitions of time-use categories. Ti is Decade 2000's for the Netherlands, Norway and the United Kingdom, and Decade 1990's for Australia, Canada, Finland and France. 


\section{APPENDIX F: Analysis for Individuals with at least one child under 5 in the household}

Table F1. Trends in leisure, paid work, unpaid work, and child care (men), individuals with at least one child under 5 in the household

\begin{tabular}{|c|c|c|c|c|c|c|c|c|c|c|}
\hline $\begin{array}{l}\text { Time-use category } \\
\text { (hours per week) }\end{array}$ & \multicolumn{2}{|c|}{ DECADE 70's } & \multicolumn{2}{|c|}{ DECADE 80's } & \multicolumn{2}{|c|}{ DECADE 90's } & \multicolumn{2}{|c|}{ DECADE 00's } & \multirow[t]{2}{*}{ Diff. } & \multirow[t]{2}{*}{ P-Value } \\
\hline \multicolumn{9}{|c|}{ Panel A: Leisure } & & \\
\hline & Mean & $\underline{\text { SD }}$ & Mean & $\underline{\text { SD }}$ & Mean & $\underline{\text { SD }}$ & Mean & $\underline{\text { SD }}$ & & \\
\hline Australia & 99.01 & $(2.08)$ & 98.75 & $(1.75)$ & 99.51 & $(0.71)$ & - & - & 0.50 & $(0.82)$ \\
\hline Canada & 101.59 & $(1.35)$ & 99.01 & $(0.72)$ & 98.36 & $(0.67)$ & - & - & -3.24 & $(0.03)$ \\
\hline Finland & 102.94 & $(1.11)$ & 100.86 & $(1.13)$ & 108.56 & $(1.57)$ & - & - & 5.62 & $(<0.01)$ \\
\hline The Netherlands & 113.85 & $(0.94)$ & 109.48 & $(0.39)$ & 104.54 & $(0.35)$ & 97.40 & $(0.73)$ & -16.45 & $(<0.01)$ \\
\hline Norway & 103.87 & $(0.99)$ & 108.26 & $(0.90)$ & 102.53 & $(0.93)$ & 101.86 & $(1.32)$ & -2.01 & $(0.22)$ \\
\hline The United Kingdom & 111.21 & $(1.01)$ & 107.43 & $(0.86)$ & 105.04 & $(3.41)$ & 107.46 & $(1.02)$ & -3.75 & $(<0.01)$ \\
\hline \multicolumn{11}{|c|}{ Panel B: Paid work } \\
\hline & $\underline{\text { Mean }}$ & $\underline{\mathrm{SD}}$ & $\underline{\text { Mean }}$ & $\underline{\text { SD }}$ & Mean & $\underline{\text { SD }}$ & $\underline{\text { Mean }}$ & $\underline{\text { SD }}$ & & \\
\hline Australia & 55.33 & $(2.39)$ & 52.52 & $(2.28)$ & 46.52 & $(0.90)$ & - & - & -8.81 & $(<0.01)$ \\
\hline Canada & 49.28 & $(1.65)$ & 47.11 & $(0.89)$ & 43.27 & $(0.85)$ & - & - & -6.01 & $(<0.01)$ \\
\hline Finland & 44.04 & $(1.33)$ & 46.36 & $(1.35)$ & 32.87 & $(1.92)$ & - & - & -11.16 & $(<0.01)$ \\
\hline The Netherlands & 38.86 & $(1.09)$ & 40.96 & $(0.49)$ & 43.88 & $(0.44)$ & 47.58 & $(0.97)$ & 8.72 & $(<0.01)$ \\
\hline Norway & 47.82 & $(1.21)$ & 39.82 & $(1.05)$ & 41.16 & $(1.10)$ & 38.93 & (1.66) & -8.89 & $(<0.01)$ \\
\hline The United Kingdom & 46.15 & $(1.21)$ & 41.45 & $(1.11)$ & 39.82 & $(3.72)$ & 36.26 & $(1.28)$ & -9.89 & $(<0.01)$ \\
\hline \multicolumn{11}{|c|}{ Panel C: Unpaid work } \\
\hline & $\underline{\text { Mean }}$ & $\underline{\mathrm{SD}}$ & $\underline{\text { Mean }}$ & $\underline{\text { SD }}$ & Mean & $\underline{\text { SD }}$ & Mean & $\underline{\text { SD }}$ & & \\
\hline Australia & 10.02 & $(0.96)$ & 10.78 & $(0.83)$ & 13.27 & $(0.40)$ & - & - & 3.25 & $(<0.01)$ \\
\hline Canada & 12.34 & $(0.77)$ & 14.54 & $(0.47)$ & 15.65 & $(0.40)$ & - & - & 3.31 & $(<0.01)$ \\
\hline Finland & 15.12 & $(0.72)$ & 14.63 & $(0.59)$ & 16.48 & $(0.94)$ & - & - & 1.36 & $(0.25)$ \\
\hline The Netherlands & 10.44 & $(0.58)$ & 12.15 & $(0.27)$ & 12.90 & $(0.26)$ & 12.47 & $(0.38)$ & 2.03 & $(<0.01)$ \\
\hline Norway & 11.54 & $(0.51)$ & 12.14 & $(0.46)$ & 15.02 & $(0.50)$ & 16.17 & $(0.72)$ & 4.64 & $(<0.01)$ \\
\hline The United Kingdom & 7.49 & $(0.46)$ & 13.44 & $(0.52)$ & 11.90 & $(2.30)$ & 15.32 & $(0.56)$ & 7.84 & $(<0.01)$ \\
\hline \multicolumn{11}{|c|}{ Panel D: Child Care } \\
\hline & Mean & $\underline{\text { SD }}$ & $\underline{\text { Mean }}$ & $\underline{\text { SD }}$ & Mean & $\underline{\text { SD }}$ & Mean & $\underline{\text { SD }}$ & & \\
\hline Australia & 3.38 & $(0.49)$ & 5.39 & $(0.44)$ & 7.26 & $(0.25)$ & - & - & 3.88 & $(<0.01)$ \\
\hline Canada & 3.57 & $(0.30)$ & 6.30 & $(0.25)$ & 9.54 & $(0.25)$ & - & - & 5.97 & $(<0.01)$ \\
\hline Finland & 4.51 & $(0.29)$ & 5.29 & $(0.33)$ & 9.04 & $(0.57)$ & - & - & 4.53 & $(<0.01)$ \\
\hline The Netherlands & 2.79 & $(0.21)$ & 3.70 & $(0.11)$ & 5.00 & $(0.15)$ & 8.66 & $(0.27)$ & 5.87 & $(<0.01)$ \\
\hline Norway & 3.85 & $(0.22)$ & 6.76 & $(0.26)$ & 8.62 & $(0.30)$ & 9.15 & $(0.47)$ & 5.30 & $(<0.01)$ \\
\hline The United Kingdom & 2.28 & $(0.16)$ & 5.08 & $(0.23)$ & 10.06 & $(1.44)$ & 7.79 & $(0.34)$ & 5.50 & $(<0.01)$ \\
\hline
\end{tabular}

Standard deviations in parenthesis. The sample is restricted to include non-retired/non-student individuals between the ages of 21 and 65 (inclusive) with at least one child under 5 in the household, see Appendix Table A1 for a description of the surveys included. Leisure, paid work, unpaid work and child care are measured in hours per week, see Table Appendix A2 for definitions of time-use categories. Ti is Decade 2000's for the Netherlands, Norway and the United Kingdom, and Decade 1990's for Australia, Canada, and Finland. 
Table F2. Trends in leisure, paid work, unpaid work, and child care (women), individuals with at least one child under 5 in the household

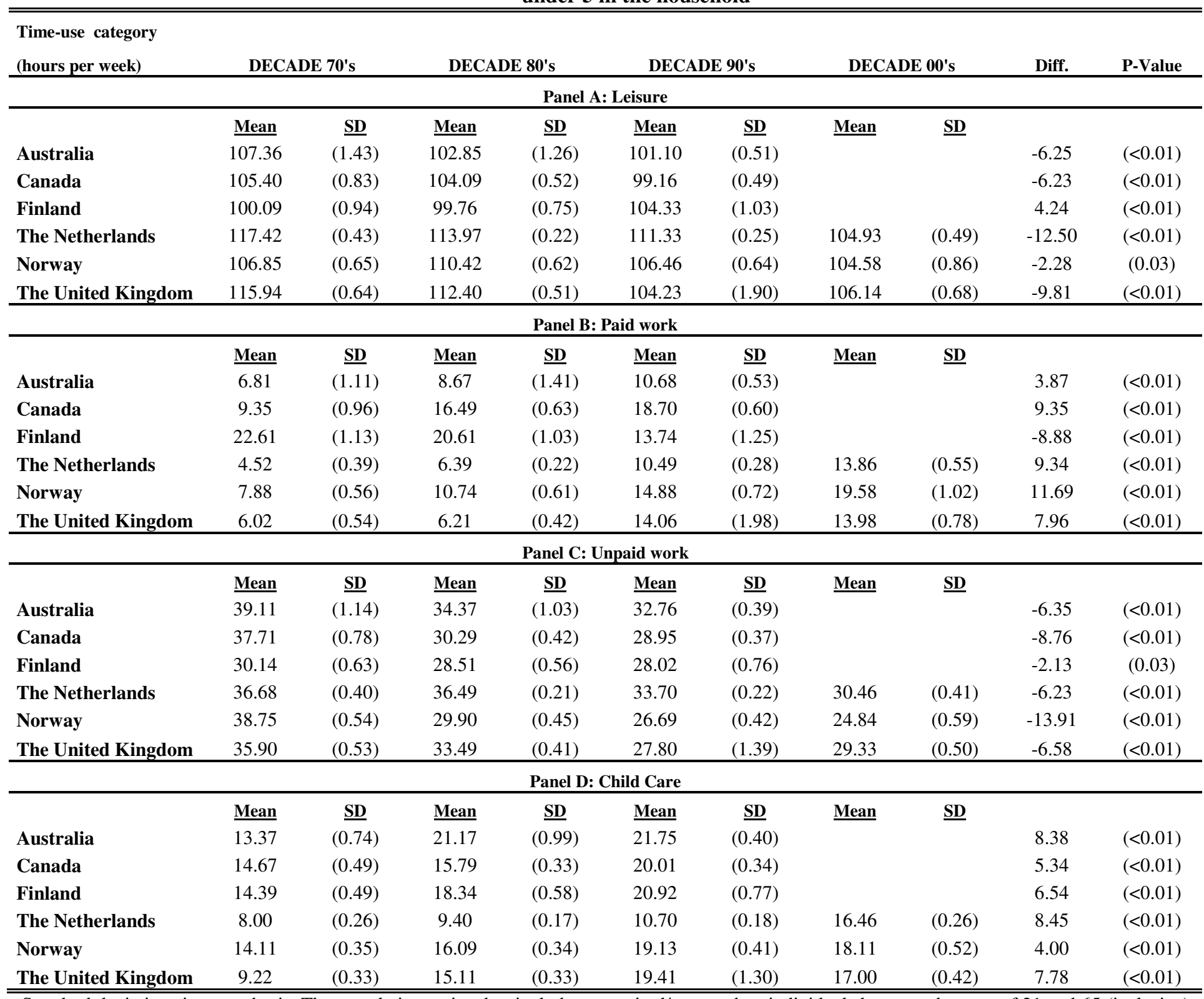

Standard deviations in parenthesis. The sample is restricted to include non-retired/non-student individuals between the ages of 21 and 65 (inclusive) with at least one child under 5 in the household, see Appendix Table A1 for a description of the surveys included. Leisure, paid work, unpaid work and child care are measured in hours per week, see Table Appendix A2 for definitions of time-use categories. Ti is Decade 2000's for the Netherlands, Norway and the United Kingdom, and Decade 1990's for Australia, Canada, and Finland. 